\title{
The contribution of $5-\mathrm{HT} 1 \mathrm{~A}$ receptors in improving plasticity and function of the brain
}

Citation for published version (APA):

Pazinatto Aguiar, R. (2020). The contribution of 5-HT1A receptors in improving plasticity and function of the brain. [Doctoral Thesis, Maastricht University]. Maastricht University. https://doi.org/10.26481/dis.20201215rp

Document status and date:

Published: 01/01/2020

DOI:

10.26481/dis.20201215rp

Document Version:

Publisher's PDF, also known as Version of record

\section{Please check the document version of this publication:}

- A submitted manuscript is the version of the article upon submission and before peer-review. There can be important differences between the submitted version and the official published version of record.

People interested in the research are advised to contact the author for the final version of the publication, or visit the DOI to the publisher's website.

- The final author version and the galley proof are versions of the publication after peer review.

- The final published version features the final layout of the paper including the volume, issue and page numbers.

Link to publication

\footnotetext{
General rights rights.

- You may freely distribute the URL identifying the publication in the public portal. please follow below link for the End User Agreement:

www.umlib.nl/taverne-license

Take down policy

If you believe that this document breaches copyright please contact us at:

repository@maastrichtuniversity.nl

providing details and we will investigate your claim.
}

Copyright and moral rights for the publications made accessible in the public portal are retained by the authors and/or other copyright owners and it is a condition of accessing publications that users recognise and abide by the legal requirements associated with these

- Users may download and print one copy of any publication from the public portal for the purpose of private study or research.

- You may not further distribute the material or use it for any profit-making activity or commercial gain

If the publication is distributed under the terms of Article $25 \mathrm{fa}$ of the Dutch Copyright Act, indicated by the "Taverne" license above, 
Cover design by Gabriel Cruz

Typesetting and lay-out by Rafael Pazinatto Aguiar

\section{Copyright @2020 Rafael Pazinatto Aguiar}

All rights reserved. No part of this thesis may be reproduced or transmitted in any form or by any means, electronic or mechanical, including photocopying, recording or any information storage or retrieval system, without permission in writing from the author, or, when appropriate, from the publisher of the publications. 


\title{
THE CONTRIBUTION OF 5-HT 1 A RECEPTORS IN IMPROVING PLASTICITY AND FUNCTION OF THE BRAIN
}

\author{
DISSERTATION \\ To obtain the degree of Doctor at Maastricht University \\ On the authority of the Rector Magnificus \\ Prof. Dr. Rianne Monique Letschert \\ In accordance with the decision of the Board of Deans \\ To be defended in public \\ On Tuesday, $15^{\text {th }}$ of December, 2020 at $12: 30$ hours
}

By

Rafael Pazinatto Aguiar 


\section{Promotor:}

Prof. Dr. J. Prickaerts

Co-promotor:

Dr. R.M.M.W. de Oliveira

\section{Evaluation committee:}

Prof. Dr. A. Blokland (Chairman)

Prof. Dr. D. van den Hove

Prof. Dr. J. Homberg

Dr. R. Schreiber

Dr. S. R. L. Joca 


\section{ABBREVIATIONS}

5-HT 5-hydroxytryptamine;

CNS Central nervous system;

DRN Dorsal raphe nucleus;

MRN Median raphe nucleus;

CRN Caudal raphe nucleus;

PFC Prefrontal cortex;

SERT Serotonin transporter;

MAO Monoamine oxidase enzyme;

5-HIAA 5-hydroxy indole acetic metabolite;

GPCR G protein-coupled receptor;

AC Adenylyl cyclase;

cAMP Cyclic adenosine monophosphate;

PLC Phospholipase C;

PI3 Inositol triphosphate;

DAG Diacylglycerol;

GIRK G protein-coupled inwardly-rectifying potassium channel;

VDCC Voltage-dependent calcium channel;

MAPK Phosphorylated mitogen-activated protein kinase;

PKC Protein kinase C;

CAMKII Calmodulin-dependent protein kinase II;

CREB CAMP-responsive binding protein;

CBF Cerebral blood flow; 
$\mathbf{F C l} \quad$ Focal cerebral ischemia;

MCA Middle cerebral artery;

MCAO MCA occlusion;

TGCI Transient global cerebral ischemia;

BCCAO Bilateral common carotid arteries occlusion;

2-Vo Two vessels occlusion;

4-Vo Four-vessel occlusion;

rtPA Recombinant tissue plasminogen activator;

SSRIs Selective serotonin reuptake inhibitors;

SNRIs Serotonin-Noradrenaline reuptake inhibitors;

Esc Escitalopram

BDNF Brain-derived neurotrophic factor

SYN Synaptophysin

PSD-95 Postsynaptic density protein-95

NeuN Neuronal nuclei

OF Open field test

EZM Elevated zero maze

OLT Object location test

FST Forced swim test

DG Dentate gyrus

OPS Object pattern separation

DCX Doublecortin 


\section{CONTENTS}

CHAPTER 1

General introduction.

CHAPTER 2

23

The $5-\mathrm{HT}_{1 \mathrm{~A}}$ receptor as a serotonergic target for neuroprotection in cerebral ischemia.

\section{CHAPTER 3}

68

Activation of 5-HT 1 A postsynaptic receptors by NLX-101 results in functional recovery and an increase in neuroplasticity in mice with brain ischemia.

\section{CHAPTER 4}

NLX-101, a biased 5-HT1A receptor agonist, improves pattern separation and stimulates neuroplasticity in aged rats.

\section{CHAPTER 5}

Involvement of the type-1 cannabinoid receptor (CB1) in the anti-stress and neuroplastic effects of antidepressants.

\section{CHAPTER 6}

General discussion

Summary

VALORIZATION

CURRICULUM VITAE 
CHAPTER 1

\author{
GENERAL INTRODUCTION
}




\section{The 5-HT $1 \mathrm{~A}$ receptor and the 'biased $5-\mathrm{HT}_{1 \mathrm{~A}}$ agonists'}

The serotonin type $1 \mathrm{~A}\left(5-\mathrm{HT}_{1 \mathrm{~A}}\right)$ receptor is an inhibitory G-protein-coupled receptor largely distributed throughout the central nervous system (CNS). 5- $\mathrm{HT}_{1 \mathrm{~A}}$ receptors localized in the raphe nuclei are somatodendritic autoreceptors that inhibit cell firing, with a consequent decrease in the extracellular levels of 5-HT in its projection areas. Postsynaptically, 5- $\mathrm{HT}_{1 \mathrm{~A}}$ receptors are found in non-5-HT neurons in 5-HT projection areas, notably in the hippocampus, cortical areas, and amygdala. Activation of heteroreceptors in these brain areas induces diverse cellular responses related to emotionality and cognition (Albert and Vahid-Ansari, 2019).

The 5- $\mathrm{HT}_{1 \mathrm{~A}}$ receptor has been subjected of intense investigation due to its involvement in numerous brain disorders, such as Parkinson's disease, Alzheimer's disease, depression, and anxiety (Wang et al., 2016; Garcia-Garcia et al., 2017; Albert and VahidAnsari et al., 2019). Antidepressant response (Haddjeri et al, 1998; Santarelli et al., 2003) and neuroprotective effects (Madhavan et al., 2003; Chilmonczyck et al., 2015; Miyazaki and Asanuma, 2016; also see Chapter 2) have also been linked to 5-HT 1A $_{\text {A }}$ receptor activation. The main pharmacological effects of $5-\mathrm{HT}_{1 \mathrm{~A}}$ receptors are dependent on the activation of the growth factor-regulated signaling pathways, including mitogen-activated protein kinase mitogen-activated protein kinase (MAPK), extracellular signal-regulated kinase 1/2 (ERK1/2), and PI3-kinase(PI3K)-Akt-GSK3 $\beta$ signaling pathways (Della Rocca et al., 1999; Chilmonczyck et al., 2015; Albert and Vahid-Ansari, 2019).

Several key pharmacological ligands including buspirone (the only commercialized 5$\mathrm{HT}_{1 \mathrm{~A}}$ agonist used as an anxiolytic) and 8-hydroxy-2-(di-n-propylamine)tetralin (8OHDPAT) have been used to characterize $5-\mathrm{HT}_{1 \mathrm{~A}}$ receptor signaling and in vivo function. However, only moderate if any therapeutic benefit was observed with these compounds. The reasons for disappointing results are likely related to several factors. 5- $\mathrm{HT}_{1 \mathrm{~A}}$ agonists in general are poorly selective and may present partial agonist activity on $5-\mathrm{HT}_{1 \mathrm{~A}}$ receptors. Buspirone, for example, may interact with 5-HT7 (Crispino et al., 2020) and dopamine $\mathrm{D}_{2}$ receptors (Le Foll et al., 2016). 5- $\mathrm{HT}_{1 \mathrm{~A}}$ receptor activation has been also shown to produce elements of serotonin behavioral syndrome and increase plasma levels of corticosterone (Koek et al., 2001). Moreover, 5- $\mathrm{HT}_{1 \mathrm{~A}}$ agonists interact broadly with 5$\mathrm{HT}_{1 \mathrm{~A}}$ subpopulations throughout the brain, irrespective of neuronal (pre- and/or post- 
synaptic receptors) or regional localization. This lack in receptor discrimination of $5-\mathrm{HT} 1 \mathrm{~A}$ agonists may result in divergent or even opposite effects.

A new generation of 5- $\mathrm{HT}_{1 \mathrm{~A}}$ receptor agonists, known as 'biased agonists', has become available and differentially activate $5-\mathrm{HT}_{1 \mathrm{~A}}$ autoreceptors or postsynaptic $5-\mathrm{HT}_{1 \mathrm{~A}}$ heteroreceptor in different brain regions (Newman-Tancredi, 2011). An interesting finding was drawn from two 5-HT 1 A agonists named F15599 (or NLX-101; Newman-Tancredi et al., 2009) and F13714 (Assie et al., 2006). Studies on their in vitro, in vivo, electrophysiological and neurochemical properties indicate that contrary to F13714, NLX101 preferentially activates post- versus presynaptic $5-\mathrm{HT}_{1 \mathrm{~A}}$ receptors and influences cortical pyramidal neuron electrical activity at lower doses than those that inhibit raphe neuron firing (Depoortere et al., 2010). The biased 5-HT1A post-synaptic receptor agonist NLX-101 has been shown to preferentially activate the postsynaptic $5-\mathrm{HT}_{1 \mathrm{~A}}$ receptor in cortical regions (Newman-Tancredi et al., 2009), improving cognitive performance and producing antidepressant- and anti-stress-like effects (Assié et al., 2010; NewmanTancredi, 2011; van Goethem et al., 2015; Depoortère et al., 2019).

Notably, differential activation of $5-\mathrm{HT}_{1 \mathrm{~A}}$ receptors has been proposed to be an attractive strategy for the management of several neurological and psychiatric conditions linked to pattern separation such as schizophrenia (Schreiber and Newman-Tancredi, 2014), anxiety (Depoortère et al., 2019), Parkinson's disease (Newman-Tancredi et al., 2018) and cerebral ischemia (Aguiar et al., 2020). Besides, selective activation of 5-HT $1 \mathrm{~A}$ receptors has shown promise results in ameliorating cognitive deficits (Depoortère et al., 2010).

\section{Cerebral ischemia}

Cerebral ischemia is caused by the interruption of blood flow and the consequent lack of energy and glucose supply to the brain. Cerebral ischemia can be broadly categorized as either focal cerebral ischemia $(\mathrm{FCl})$ or stroke, that occurs due to a thrombotic or embolic occlusion in a particular cerebral artery and, transient global cerebral ischemia (TGCI), as a result of reversible cardiac arrest. Cognitive dysfunctions, anxiety, and depression are prominent and long-term symptoms of transient forms of cerebral ischemia (Moulaert et al., 2010; Ayerbe et al., 2013). These symptoms have 
been related to neuronal degeneration and a decline in synaptic plasticity that are induced by ischemic injury in the brain (Carmichael, 2011).

The neuropsychiatric consequences of cerebral ischemia are often underrecognized and undertreated, even though they are highly prevalent (Jokinen et al., 2015; Winstein et al., 2016). Despite continuous efforts both at the experimental and clinical levels, the only approved pharmacological treatment has been restricted to the tissue plasminogen activator (tPA; National Institute of Neurological Disorders and Stroke Recombinant Tissue Plasminogen Activator Stroke Study Group, 1995). However, the narrow time window of treatment $(4.5 \mathrm{hs})$ and the possible occurrence of hemorrhage limit its applicability to a minority of patients (Hacke et al., 2008). No other specific pharmacological treatment is available to treat either focal or global cerebral ischemic consequences. Therefore, there is a clear necessity for alternative pharmacological treatments, which might increase the number of patient survivors as well as the functional outcomes of cerebral ischemic diseases.

Experimental models of cerebral ischemia have contributed to understanding the underlying disease mechanisms and the effects of several pharmacological treatments. In rodents, $\mathrm{FCl}$ can be modeled through transient or permanent occlusion of the middle cerebral artery (MCAo) while $\mathrm{TGCl}$ can be achieved by bilateral common carotid artery occlusion (BCCAO) or 4-vessel occlusion (4-VO) (León-Moreno et al., 2020). Despite particular aspects, the pathophysiological mechanisms that lead to neurodegeneration due to $\mathrm{FCl}$ or $\mathrm{TGCl}$ seem to be similar (Leker and Shohami, 2002). Both procedures induce hippocampal and cortical neurodegeneration, learning and memory dysfunctions, and emotional impairments (Kumaran et al., 2008; Bora et al., 2011; Rajput et al., 2011; Soares et al., 2013).

From a therapeutic point of view, the selective reuptake serotonin inhibitor (SSRI) escitalopram (Esc) improves clinical recovery and decreases disability in patients who survive cerebral ischemia (Dam et al., 1996; Zittel et al. 2008; Acler et al., 2009; Jorge et al., 2010; Chollet et al., 2011; Sunami et al., 2012; Mead et al., 2013; Siepmann et al., 2015). Besides, SSRIs have been shown to restore functional behaviors, reduce neuronal death, exert anti-inflammatory effects, influence neurogenesis, and stimulate neuroplasticity in rodent models of FCI and TGCI (Kim et al., 2007; Lim et al., 2009; Lee 
et al., 2011; Dhami et al., 2013; Espinera et al., 2013). The neuroprotective effects of SSRIs on brain ischemia have been related to the activation of $5-\mathrm{HT}_{1 \mathrm{~A}}$ receptors (BodeGreuel et al., 1990; Schaper et al., 2000; Klisch et al., 2003). Thus 5-HT1A receptor agonists have emerged as a potential target to promote neuroprotection in ischemic cerebral disease (Ramos et al., 2004; Pazos et al., 2013; Johansen et al., 2014; Hind et al., 2016).

\section{Aging and pattern separation}

A decline in cognitive functions is part of normal aging (Salthouse, 2003). One of the most cognitive function commonly reported deficits associated with aging is memory loss. In particular, age-related spatial memory decline has been well-documented in both humans and animal models (lachini et al., 2009; Sharma et al., 2010; Holden and Gilbert, 2012). An important aspect of spatial memory is the ability to encode newly formed memories in a discrete non-overlapping fashion to reduce interference between similarly encoded memories (Tulving and Markowitsch, 1998). This process of discriminating between similar contextual memories has been referred as pattern separation (Clelland et al., 2009). Pattern separation performance has been used as a predictor for the development of cognitive impairments in pre-dementia and dementia (Reagh et al., 2013), anxiety disorders (Kheirbeck et al., 2012), schizophrenia (Das et al., 2014; Scheiber and Newman-Tancredi, 2014) and Alzheimer's disease (Parizhova et al., 2020).

Multiple mechanisms have been proposed to explain pattern separation but the exact process is not fully understood yet. The dentate gyrus (DG) of the hippocampus is thought to function as a pattern separator (Aimone et al., 2011; Sahay et al., 2011; Yassa and Stark, 2011). As such, the DG takes similar patterns of neural activity and converts them into distinct representations. This is thought to be achieved via dispersion of entorhinal cortical inputs onto the granule cells within the DG which subsequently sends the information to CA3 pyramidal cells (Kheirbek et al., 2012). The CA3-DG circuit of the hippocampus is continuously modified by the integration of newborn neurons (Miller and Sahay, 2019). Of note, the ablation of adult neurogenesis impairs pattern separation (Deng et al., 2010; Tronel et al., 2010). Other studies have found DG dysfunction and 
pattern separation impairments during aging in non-human primates (Small et al., 2004) and humans (Yassa et al., 2011).

5- $\mathrm{HT}_{1 \mathrm{~A}}$ receptors, present in the hippocampal DG (Banasr et al., 2004; Radley and Jacobs, 2002), have been shown to interfere with spatial pattern separation (Koenig et al., 2008; van Goethem et al., 2015). Moreover, activation of these 5-HT1A receptors improves cognition via mechanisms involving adult hippocampal neurogenesis (Radley and Jacobs, 2002; Schreiber and Newman-Tancredi, 2014). Therefore, biased 5-HT1A postsynaptic receptor agonists might be a strategy for memory, in particular pattern separartion, improvement in age-related cognitive disorders.

\section{5- $\mathrm{HT}_{1 \mathrm{~A}}$ receptors and neuroplasticity}

Neuroplasticity can be defined as the brain's ability to change, remodel, and reorganize when subjected to new experiences or injury (Nudo et al., 2006; Dan, 2019). Neuroplasticity can occur on various functional and structural levels. In the adult brain, neuroplasticity plays an important role in altering the state of excitability, controlling behavioral responses, and in the recovery of trauma. Neuroplastic processes include neurochemical responses that alter synaptic functions such as growth and branching of dendrites, remodeling of synaptic contacts, and neurogenesis (Bruel-Jungerman et al., 2007; Drapeau and Nora Abrous, 2008; Gulyaeva, 2017). These processes are regulated by intracellular pathways, metabolic processes, epigenetic mechanisms, neurotrophic factors, and neurotransmitter systems (Mattson et al., 2018).

Several conditions can impact neuroplasticity in brain regions related to the control of emotions and cognition, such as the hippocampus and prefrontal cortex (PFC). The hippocampus, in particular, is a brain structure with profound functional and structural plasticity across the lifespan in humans and rodents. This high degree of hippocampal plasticity, however, is as already mentioned above accompanied by a pronounced vulnerability to deleterious conditions such as ischemia, neuroinflammation, chronic stress, and aging (Bartsch et al., 2015).

A brief episode of cerebral ischemia, for example, results in significant cell death in the CA1 hippocampal area which is reflected by deficits in spatial memory (Pulsinelli et al., 1982; Kirino, 2000). Interestingly, as a compensatory mechanism, cerebral ischemia 
stimulates cell proliferation in the hippocampal DG, thereby giving rise to newly generated neurons and supporting the activity-dependent role of adult neurogenesis in hippocampal plasticity (Miles and Kernie, 2008). Importantly, multiple studies indicate that $5-\mathrm{HT}_{1 \mathrm{~A}}$ receptor signaling in the DG contributes to SSRI-mediated neurogenesis (Samuels et al., 2015; Segi-Nishida, 2017) and promotes neuroprotective effects after experimental cerebral ischemia (Ramos et al., 2004; Pazos et al., 2013; Johansen et al., 2014)

Another condition affecting hippocampal neuroplasticity is aging. Age-related cognitive impairments correlate with decreased synaptic plasticity such as decreased hippocampal neurogenesis, deficits in the maintenance of hippocampal long term potentiation (LTP), and reduced density of dendritic spines (Jiang et al., 2015). Interestingly, preferential activation of $5-\mathrm{HT}_{1 \mathrm{~A}}$ postsynaptic receptors has shown promising results in ameliorating cognitive dysfunction (Depoortère et al., 2010), improving pattern separation performance (van Goethem et al., 2015), and exerting antidepressant- and anti-stress-like effects (Assié et al., 2010; Newman-Tancredi et al., 2011; Depoortère et al., 2019). However, all these effects were only investigated and observed in healthy adult rodents.

To summarize, based on the findings above it is interesting to investigate the contribution of $5-\mathrm{HT}_{1 \mathrm{~A}}$ receptor activation with biased receptor agonists in improving brain plasticity and functional recovery in for instance ischemia and aging. 


\section{AIM AND OUTLINE OF THIS THESIS}

This thesis aimed to investigate the contribution of $5-\mathrm{HT}_{1 \mathrm{~A}}$ receptor activation in improving brain plasticity and functional recovery in different experimental conditions. The biased 5-HT 1 A receptor agonist NLX-101 (a.k.a F15599) was used to stimulate 5- $\mathrm{HT}_{1 \mathrm{~A}}$ postsynaptic receptors in cerebral ischemia and aging animals. It was addressed whether

the NLX-101 was more efficacious in improving brain plasticity and functional recovery in experimental cerebral ischemia compared to reference drugs, due to its higher selectivity for, intrinsic activity at, and stimulation of postsynaptic receptors in the cerebral cortex. In a parallel study, the involvement of the type-1 cannabinoid receptor (CB1) in the antistress and neuroplasticity effects of different classes of antidepressants was investigated by testing Esc and Venlafaxine (VFX).

Chapter 2 presents an overview of the $5-\mathrm{HT}_{1 \mathrm{~A}}$ receptor and its potential for neuroprotection in cerebral ischemic diseases. Specifically, this chapter contains a brief description of rodent models of cerebral ischemia, the pathophysiology of cerebral ischemia, and the putative mechanisms underlying the effects of $5-\mathrm{HT}_{1 \mathrm{~A}}$ receptor agonists in these conditions. Also, insights are provided into the 'biased' $5-\mathrm{HT}_{1 \mathrm{~A}}$ receptor agonists, as an attractive strategy providing neuroprotection in cerebral ischemia.

Chapter 3 deals with the question of whether the preferential $5-\mathrm{HT}_{1 \mathrm{~A}}$ postsynaptic receptor agonist NLX-101 or the SSRI Esc mitigated cognitive and emotional impairments in mice subjected to the bilateral common carotid artery occlusion (BCCAO). The animals were treated with NLX-101 or Esc for 28 days and then evaluated in a battery of behavioral tests. The mice's brains were processed to access the impact of NLX-101 and Esc on key proteins related to synaptic plasticity, including brain-derived neurotrophic factor (BDNF), synaptophysin (SYN), and postsynaptic density protein-95 (PSD-95). Dendritic remodeling in the hippocampus and PFC was also investigated.

Chapter 4 focuses on the effects of acute or repeated treatment with NLX-101 in aging rats evaluated in the spatial object pattern separation (OPS) task. The brains were collected to identify neuroplasticity markers (BDNF, PSD95, SYN) and neurogenesis in the hippocampus. 
Chapter 5 presents behavioral and neuroplasticity effects observed by repeated treatment with the SSRI Esc, or the selective serotonin and noradrenaline reuptake inhibitor (SSNRI) VFX, in chronically stressed mice. It was investigated whether the effects of Esc or VFX were dependent on CB1 receptor activation. For this, male mice were submitted to a chronic unpredictable stress (CUS) paradigm for 21 days and received Esc or VFX once a day, in the presence or not of the CB1 receptor antagonist AM251. Behavioral tests were conducted to evaluate depressive- and anxiety-like behaviors and the brains were collected to investigate neuroplasticity.

Finally, in Chapter 6 a general discussion is provided, followed in Chapter $\mathbf{7}$ by a short summary of the main findings and present conclusions arising from all studies. 


\section{References}

Aimone JB, Deng W, Gage FH. 2011. Resolving new memories: a critical look the dentate gyrus, adult neurogenesis, and pattern separation. Neuron. 70(4):589596.

Acler M, Robol E, Fiaschi A, Manganotti P. 2009. A double blind placebo RCT to investigate the effects of serotonergic modulation on brain excitability and motor recovery in stroke patients. J. Neurol. 256(7), 1152-1158.

Aguiar RP, Soares LM, Meyer E, et al. 2020. Activation of 5-HT1A postsynaptic receptors by NLX-101 results in functional recovery and an increase in neuroplasticity in mice with brain ischemia. Prog Neuropsychopharmacol Biol Psychiatry. 99:109832.

Albert PR, Vahid-Ansari F. 2019. The 5-HT1A receptor: Signaling to behavior. Biochimie. 161:34-45.

Assié MB, Lomenech H, Ravailhe V, Faucillon V, Newman-Tancredi A. 2006. Rapid desensitization of somatodendritic 5-HT1A receptors by chronic administration of the high-efficacy 5-HT1A agonist, F13714: a microdialysis study in the rat. $\mathrm{Br} \mathrm{J}$ Pharmacol. 149(2):170-178.

Assié MB, Bardin L, Auclair AL, Carilla-Durand E, Depoortère R, Koek W, Kleven, MS, Colpaert F, Vacher B, Newman-Tancredi A. 2010. F15599, a highly selective postsynaptic 5-HT(1A) receptor agonist: in-vivo profile in behavioural models of antidepressant and serotonergic activity. Int $J$ Neuropsychopharmacol. 13(10), 1285-1298.

Ayerbe L, Ayis S, Wolfe CD, Rudd AG. 2013. Natural history, predictors and outcomes of depression after stroke: systematic review and meta-analysis. $\mathrm{Br} \mathrm{J}$ Psychiatry. 202(1), 14-21.

Banasr M, Hery M, Printemps R, Daszuta A. 2004. Serotonin-induced increases in adult cell proliferation and neurogenesis are mediated through different and common 5HT receptor subtypes in the dentate gyrus and the subventricular zone. Neuropsychopharmacology. 29(3):450-460.

Bartsch T, Döhring J, Reuter S, Finke C, Rohr A, Brauer H, Deuschl G, Jansen O. 2015. Selective neuronal vulnerability of human hippocampal CA1 neurons: lesion evolution, temporal course, and pattern of hippocampal damage in diffusionweighted MR imaging. J Cereb Blood Flow Metab. 35(11):1836-45.

Bora KS, Arora S, Shri R. 2011. Role of Ocimum basilicum L. in prevention of ischemia and reperfusion-induced cerebral damage, and motor dysfunctions in mice brain. $J$ Ethnopharmacol. 137(3):1360-1365.

Bode-Greuel KM, Klisch J, Horváth E, Glaser T, Traber J. 1990. Effects of 5hydroxytryptamine1A-receptor agonists on hippocampal damage after transient forebrain ischemia in the Mongolian gerbil. Stroke. 21(12 Suppl):IV164-IV166.

Bruel-Jungerman E, Davis S, Laroche S. 2007. Brain plasticity mechanisms and memory: a party of four. Neuroscientist. 13(5):492-505.

Chilmonczyk Z, Bojarski AJ, Pilc A, Sylte I. 2015. Functional Selectivity and Antidepressant Activity of Serotonin 1A Receptor Ligands. Int $\mathrm{J}$ Mol Sci. 16(8):18474-18506.

Crispino M, Volpicelli F, Perrone-Capano C. 2020. Role of the Serotonin Receptor 7 in Brain Plasticity: From Development to Disease. Int J Mol Sci. 2020;21(2):505. 
Carmichael ST. 2011. Brain excitability in stroke: the yin and yang of stroke progression. Arch Neurol 69(2), 161-167.

Clelland CD, Choi M, Romberg C, et al. 2009. A functional role for adult hippocampal neurogenesis in spatial pattern separation. Science. 325(5937):210-213.

Chollet F, Tardy J, Albucher JF, Thalamas C, Berard E, Lamy C, Bejot Y, Deltour S, Jaillard A, Niclot P, Guillon B, Moulin T, Marque P, Pariente J, Arnaud C, Loubinoux I. 2011. Fluoxetine for motor recovery after acute ischaemic stroke (FLAME): a randomised placebo-controlled trial. Lancet Neurol. 10(2), 123-130.

Dam M, Tonin P, De Boni A, Pizzolato G, Casson S, Ermani M, Freo U, Piron L, Battistin L. 1996. Effects of fluoxetine and maprotiline on functional recovery in poststroke hemiplegic patients undergoing rehabilitation therapy. Stroke. 27(7), 1211-1214.

Dan B. 2019. Neuroscience underlying rehabilitation: what is neuroplasticity? Dev Med Child Neurol. 61(11):1240.

Das T, Ivleva EI, Wagner AD, Stark CE, Tamminga CA. 2014. Loss of pattern separation performance in schizophrenia suggests dentate gyrus dysfunction. Schizophr Res. 159(1):193-197.

Depoortère R, Bardin L, Varney MA, Newman-Tancredi A. 2019. Serotonin 5$\mathrm{HT}_{1 \mathrm{~A}}$ Receptor Biased Agonists Display Differential Anxiolytic Activity in a Rat Social Interaction Model. ACS Chem Neurosci.10(7):3101-3107.

Depoortère R, Auclair AL, Bardin L, Colpaert FC, Vacher B, Newman-Tancredi A. 2010. F15599, a preferential post-synaptic $5-\mathrm{HT} 1 \mathrm{~A}$ receptor agonist: activity in models of cognition in comparison with reference 5-HT1A receptor agonists. Eur Neuropsychopharmacol. 20(9):641-654.

Depoortère R, Papp M, Gruca P, et al. 2019. Cortical 5-hydroxytryptamine 1A receptor biased agonist, NLX-101, displays rapid-acting antidepressant-like properties in the rat chronic mild stress model. J Psychopharmacol. 33(11):1456-1466.

Della Rocca GJ, Mukhin YV, Garnovskaya MN, et al. 1999. Serotonin 5-HT1A receptormediated Erk activation requires calcium/calmodulin-dependent receptor endocytosis. J Biol Chem. 274(8):4749-4753.

Drapeau E, Nora Abrous D. 2008. Stem cell review series: role of neurogenesis in agerelated memory disorders. Aging Cell. 7(4):569-589.

Dhami KS, Churchward MA, Baker GB, Todd KG. 2013. Fluoxetine and citalopram decrease microglial release of glutamate and $\mathrm{D}$-serine to promote cortical neuronal viability following ischemic insult. Mol Cell Neurosci 56, 365-374.

Deng W, Aimone JB, Gage FH. 2010. New neurons and new memories: how does adult hippocampal neurogenesis affect learning and memory?. Nat Rev Neurosci. 11(5):339-350.

Espinera AR, Ogle ME, Gu X, Wei L. 2013. Citalopram enhances neurovascular regeneration and sensorimotor functional recovery after ischemic stroke in mice. Neuroscience. 247, 1-11.

Garcia-Garcia AL, Meng Q, Canetta S, et al. 2017. Serotonin Signaling through Prefrontal Cortex 5- $\mathrm{HT}_{1 \mathrm{~A}}$ Receptors during Adolescence Can Determine Baseline Mood-Related Behaviors. Cell Rep. 18(5):1144-1156.

Gulyaeva NV. 2017. Molecular Mechanisms of Neuroplasticity: An Expanding Universe. Biochemistry (Mosc). 82(3):237-242. 
Hacke W, Lichy C. 2008. Thrombolysis for acute stroke under antiplatelet therapy: safe enough to be beneficial?. Nat Clin Pract Neurol. 4(9):474-475.

Holden HM, Gilbert PE. 2012. Less efficient pattern separation may contribute to agerelated spatial memory deficits. Front Aging Neurosci. 4:9.

Haddjeri N, Blier P, de Montigny C. 1998. Long-term antidepressant treatments result in a tonic activation of forebrain 5-HT1A receptors. J Neurosci. 1998;18(23):1015010156.

lachini I, lavarone A, Senese VP, Ruotolo F, Ruggiero G. 2009. Visuospatial memory in healthy elderly, $A D$ and $\mathrm{MCl}$ : a review. Curr Aging Sci. 2(1):43-59.

Jokinen $\mathrm{H}$, Melkas S, Ylikoski R, et al. 2015. Post-stroke cognitive impairment is common even after successful clinical recovery. Eur J Neurol. 22(9):1288-1294.

Jorge RE, Acion L, Moser D, Adams HPJ, Robinson RG. 2010. Escitalopram and enhancement of cognitive recovery following stroke. Arch Gen Psychiatry. 67(2), 187-196.

Johansen FF, Hasseldam H, Nybro Smith M, Rasmussen RS. 2014. Drug-induced hypothermia by $5 \mathrm{HT} 1 \mathrm{~A}$ agonists provide neuroprotection in experimental stroke: new perspectives for acute patient treatment. J Stroke Cerebrovasc Dis. 23(10):2879-2887.

Koek W, Vacher B, Cosi C, Assié MB, Patoiseau JF, Pauwels PJ, Colpaert FC, 2001. 5HT1A receptor activation and antidepressant-like effects: $F 13714$ has high efficacy and marked antidepressant potential. Eur J Pharmacol. 420(2-3), 103112.

Koenig J, Cosquer B, Cassel JC. 2008. Activation of septal 5-HT1A receptors alters spatial memory encoding, interferes with consolidation, but does not affect retrieval in rats subjected to a water-maze task. Hippocampus 18: 99- 118.

Kumaran D, Udayabanu M, Nair RU, R A, Katyal A. 2008. Benzamide protects delayed neuronal death and behavioural impairment in a mouse model of global cerebral ischemia. Behav Brain Res. 192(2):178-184.

Kim DH, Li H, Yoo KY, Lee BH, Hwang IK, Won MH. 2007. Effects of fluoxetine on ischemic cells and expressions in BDNF and some antioxidants in the gerbil hippocampal CA1 region induced by transient ischemia. Exp Neurol. 204(2), 748758.

Kirino T.2000. Delayed neuronal death. Neuropathology. 20 Suppl:S95-7.

Kheirbek MA, Drew LJ, Burghardt NS, et al. 2012. Differential control of learning and anxiety along the dorsoventral axis of the dentate gyrus. Neuron. 77(5):955-968.

Klisch J, Bode-Greuel KM, Horvath E, Klisch C, Els T. 2003. Additive neuroprotective effect of Ketanserin and Ipsapirone on the hippocampal damage after transient forebrain ischemia in the Mongolian gerbil. Neurosci Lett. 342(1-2):25-28.

Le Foll B, Payer D, Di Ciano P, et al. 2016. Occupancy of Dopamine D3 and D2 Receptors by Buspirone: A [11C]-(+)-PHNO PET Study in Humans. Neuropsychopharmacology. 2016;41(2):529-537. doi:10.1038/npp.2015.177

Lee CH, Park JH, Yoo KY, Choi JH, Hwang IK, Ryu PD, Kim DH, Kwon YG, Kim YM, Won $\mathrm{MH}$. 2011. Pre- and post-treatments with escitalopram protect against experimental ischemic neuronal damage via regulation of BDNF expression and oxidative stress. Exp Neurol. 229(2), 450-459. 
Leker RR, Shohami E. 2002. Cerebral ischemia and trauma-different etiologies yet similar mechanisms: neuroprotective opportunities. Brain Res Brain Res Rev. 39(1):5573.

Lim CM, Kim SW, Park JY, Kim C, Yoon SH, Lee JK. 2009. Fluoxetine affords robust neuroprotection in the postischemic brain via its anti-inflammatory effect. $J$. Neurosci Res. 87(4), 1037-1045.

Madhavan L, Freed WJ, Anantharam V, Kanthasamy AG. 2003. 5-Hydroxytryptamine $1 \mathrm{~A}$ receptor activation protects against $\mathrm{N}$-methyl-D-aspartate-induced apoptotic cell death in striatal and mesencephalic cultures. J. Pharmacol. Exp. Ther. 304:913-923.

Mead GE, Hsieh CF, Lee R, Kutlubaev M, Claxton A, Hankey GJ, Hackett M, 2013. Selective serotonin reuptake inhibitors for stroke recovery: a systematic review and meta-analysis. Stroke. 44(3), 844-850.

Miyazaki I, Asanuma M. 2016. Serotonin 1A Receptors on Astrocytes as a Potential Target for the Treatment of Parkinson's Disease. Curr Med Chem. 23(7):686-700.

Moulaert VR, Wachelder EM, Verbunt JA, Wade DT, van Heugten CM. 2010. Determinants of quality of life in survivors of cardiac arrest. $J$ Rehabil Med. 42(6):553-558.

Miller SM, Sahay A. 2019. Functions of adult-born neurons in hippocampal memory interference and indexing. Nat Neurosci. 22(10):1565-1575.

Miles DK, Kernie SG. 2008. Hypoxic-ischemic brain injury activates early hippocampal stem/progenitor cells to replace vulnerable neuroblasts. Hippocampus. 18(8):793806.

Mattson MP, Moehl K, Ghena N, Schmaedick M, Cheng A. 2018. Intermittent metabolic switching, neuroplasticity and brain health. Nat Rev Neurosci. 19(2):63-80.

National Institute of Neurological Disorders and Stroke rt-PA Stroke Study Group. 1995. Tissue plasminogen activator for acute ischemic stroke. $N$ Engl $J$ Med. 333(24):1581-1587.

Newman-Tancredi, A. 2011 Biased agonism at serotonin 5-HT1A receptors: Preferential postsynaptic activity for improved therapy of CNS disorders. Neuropsychiatry, 1(2):149-164.

Newman-Tancredi A, Martel JC, Assié MB, et al. 2009. Signal transduction and functional selectivity of $\mathrm{F} 15599$, a preferential post-synaptic 5-HT1A receptor agonist. $\mathrm{Br} \mathrm{J}$ Pharmacol. 156(2):338-353.

Newman-Tancredi A, Varney MA, McCreary AC. 2018. Effects of the Serotonin 5$\mathrm{HT}_{1 \mathrm{~A}}$ Receptor Biased Agonists, F13714 and F15599, on Striatal Neurotransmitter Levels Following L-DOPA Administration in Hemi-Parkinsonian Rats. Neurochem Res. 43(5):1035-1046.

Nudo RJ. 2006. Plasticity. NeuroRx. 3(4):420-7.

Pazos MR, Mohammed N, Lafuente H, Santos M, Martínez-Pinilla E, Moreno E, Valdizan E, Romero J, Pazos A, Franco R, Hillard CJ, Alvarez FJ, Martínez-Orgado J, 2013. Mechanisms of cannabidiol neuroprotection in hypoxic-ischemic newborn pigs: role of $5 \mathrm{HT}(1 \mathrm{~A})$ and CB2 receptors. Neuropharmacology. 71, 282-291.

Parizkova M, Lerch O, Andel R, et al. 2020. Spatial Pattern Separation in Early Alzheimer's Disease. J Alzheimers Dis. 76(1):121-138. 
Pulsinelli WA, Brierley JB, Plum F. 1982. Temporal profile of neuronal damage in a model of transient forebrain ischemia. Ann Neurol. 11(5):491-8.

Ramos AJ, Rubio MD, Defagot C, Hischberg L, Villar MJ, Brusco A. 2004. The 5HT1A receptor agonist, 8-OH-DPAT, protects neurons and reduces astroglial reaction after ischemic damage caused by cortical devascularization. Brain Res. 1030(2), 201-220.

Rajput SK, Siddiqui MA, Kumar V, et al. 2011. Protective effects of L-pGlu-(2-propyl)-LHis-L-ProNH2, a newer thyrotropin releasing hormone analog in in vitro and in vivo models of cerebral ischemia. Peptides. 32(6):1225-1231.

Reagh ZM, Roberts JM, Ly M, DiProspero N, Murray E, Yassa MA. 2014. Spatial discrimination deficits as a function of mnemonic interference in aged adults with and without memory impairment. Hippocampus. 24(3):303-314.

Radley JJ, Jacobs BL. 2002. 5-HT1A receptor antagonist administration decreases cell proliferation in the dentate gyrus. Brain Res. 955(1-2):264-267.

Santarelli L, Saxe M, Gross C, et al. 2003. Requirement of hippocampal neurogenesis for the behavioral effects of antidepressants. Science. 301(5634):805-809.

Salthouse TA. 2003. Memory aging from 18 to 80. Alzheimer Dis Assoc Disord.17(3):162167.

Samuels BA, Anacker C, Hu A, Levinstein MR, Pickenhagen A, Tsetsenis T, Madroñal N, Donaldson ZR, Drew LJ, Dranovsky A, Gross CT, Tanaka KF, Hen R. 2015. 5HT1A receptors on mature dentate gyrus granule cells are critical for the antidepressant response. Nat Neurosci. 18(11):1606-16.

Segi-Nishida E. 2017. The Effect of Serotonin-Targeting Antidepressants on Neurogenesis and Neuronal Maturation of the Hippocampus Mediated via 5-HT1A and 5-HT4 Receptors. Front Cell Neurosci. 11:142.

Schreiber R, Newman-Tancredi A. 2014. Improving cognition in schizophrenia with antipsychotics that elicit neurogenesis through $5-\mathrm{HT}(1 \mathrm{~A})$ receptor activation. Neurobiol Learn Mem. 110:72-80.

Soares LM, Schiavon AP, Milani H, de Oliveira RM. 2013. Cognitive impairment and persistent anxiety-related responses following bilateral common carotid artery occlusion in mice. Behav Brain Res. 249:28-37.

Siepmann T, Kepplinger J, Zerna C, Schatz U, Penzlin Al, Pallesen LP, Illigens BM, Weidner K, Reichmann H, Puetz V, Bodechtel U, Barlinn K. 2015. The effects of pretreatment versus de novo treatment with selective serotonin reuptake inhibitors on short-term outcome after acute ischemic stroke. J Stroke Cerebrovasc Dis. 8, 1886-1892.

Sunami E, Usuda K, Nishiyama Y, Otori T, Katsura K, Katayama Y. 2012. A preliminary study of fluvoxamine maleate on depressive state and serum melatonin levels in patients after cerebral infarction. Intern Med.51(10), 1187-1193.

Schaper C, Zhu Y, Kouklei M, Culmsee C, Krieglstein J. 2000. Stimulation of 5-HT(1A) receptors reduces apoptosis after transient forebrain ischemia in the rat. Brain Res. 883(1):41-50.

Sharma S, Rakoczy S, Brown-Borg H. 2010. Assessment of spatial memory in mice. Life Sci. 87(17-18):521-536.

Sahay A, Wilson DA, Hen R. 2011. Pattern separation: a common function for new neurons in hippocampus and olfactory bulb. Neuron. 70(4):582-588. 
Small SA, Chawla MK, Buonocore M, Rapp PR, Barnes CA. 2004. Imaging correlates of brain function in monkeys and rats isolates a hippocampal subregion differentially vulnerable to aging. Proc Natl Acad Sci U S A.101(18):7181-7186.

Tulving E, Markowitsch HJ. 1998. Episodic and declarative memory: role of the hippocampus. Hippocampus. 8(3):198-204.

Tronel S, Belnoue L, Grosjean N, et al. 2012. Adult-born neurons are necessary for extended contextual discrimination. Hippocampus. 22(2):292-298.

van Goethem NP, Schreiber R, Newman-Tancredi A, Varney M, Prickaerts J. 2015. Divergent effects of the 'biased' 5-HT1 A receptor agonists F15599 and F13714 in a novel object pattern separation task. Br J Pharmacol.172(10):2532-2543.

Wang L, Zhou C, Zhu D, et al. 2016. Serotonin-1A receptor alterations in depression: a meta-analysis of molecular imaging studies. BMC Psychiatry. 16(1):319.

Winstein CJ, Stein J, Arena R, et al. 2016. Guidelines for Adult Stroke Rehabilitation and Recovery: A Guideline for Healthcare Professionals From the American Heart Association/American Stroke Association. Stroke. 47(6):e98-e169.

Yassa MA, Stark CE. 2011. Pattern separation in the hippocampus. Trends Neurosci. 34(10):515-525.

Yassa MA, Lacy JW, Stark SM, Albert MS, Gallagher M, Stark CE. 2011. Pattern separation deficits associated with increased hippocampal CA3 and dentate gyrus activity in nondemented older adults. Hippocampus. 21(9):968-979.

Zittel S, Weiller C, Liepert J. 2008. Citalopram improves dexterity in chronic stroke patients. Neurorehabil Neural Repair. 22(3), 311-314. 


\section{CHAPTER 2}

\section{THE 5-HT ${ }_{1 A}$ RECEPTOR AS A SEROTONERGIC TARGET FOR NEUROPROTECTION IN CEREBRAL ISCHEMIA}

Aguiar RP, Newman-Tancredi A, Prickaerts J, de Oliveira RMW.

Submitted to Progress in Neuro-Psychopharmacology \& Biological Psychiatry, 2020. 


\section{Abstract}

Cerebral ischemia due to stroke or cardiac arrest greatly affects daily functioning and the quality of life of patients and has a high socioeconomic impact due to the surge in their prevalence. Advances in the identification of an effective pharmacotherapy to promote neuroprotection and recovery after a cerebral ischemic insult are, however, limited. The serotonin $1 \mathrm{~A}\left(5-\mathrm{HT}_{1 \mathrm{~A}}\right)$ receptor has been implicated in the regulation of several brain functions, including mood, emotions, memory, and neuroplasticity, all of which are deleteriously affected by cerebral ischemia. This review focuses on the specific roles and mechanisms of $5-\mathrm{HT}_{1 \mathrm{~A}}$ receptors in neuroprotection in experimental models of cerebral ischemia. We present experimental evidence that $5-\mathrm{HT}_{1 \mathrm{~A}}$ receptor agonists can prevent neuronal damage and promote functional recovery induced by focal and transient global ischemia in rodents. However, indiscriminate activation of pre-and postsynaptic by nonbiased $5-\mathrm{HT}_{1 \mathrm{~A}}$ receptor agonists may be a limiting factor in the anti-ischemic clinical efficacy of these compounds since 5- $\mathrm{HT}_{1 \mathrm{~A}}$ receptors in different brain regions can mediate diverging or even contradictory responses. Current insights are presented into the 'biased' 5- $\mathrm{HT}_{1 \mathrm{~A}}$ post-synaptic heteroreceptor agonist NLX-101 (also known as F15599), a compound that preferentially and potently stimulates postsynaptic cortical pyramidal neurons without inhibiting firing of serotoninergic neurons, as a potential strategy providing neuroprotection in cerebral ischemic conditions.

Keywords: cerebral ischemia, serotonin, $5-\mathrm{HT}_{1 \mathrm{~A}}$ receptor, neuroprotection 


\section{Introduction}

Cerebral ischemia resulting from stroke or cardiac arrest and is one of the leading causes of death and disability worldwide, presenting a significant global burden to patients, their relatives, and entire economies (Flynn et al., 2008; Benjamin et al., 2018; Rajsic et al., 2019). Patients who survive an ischemic cerebral insult are particularly vulnerable to the development of motor and cognitive impairments, depression, and anxiety disorders (Moulaert et al., 2010; Geri et al., 2014). Despite intense preclinical efforts, however, only limited advances have been made to develop effective therapies to promote recovery from cerebral ischemia (Ginsberg, 2009; Dirnagl and Endres, 2014).

Serotonin $5-\mathrm{HT}_{1 \mathrm{~A}}$ receptors have been implicated in the regulation of several brain functions such as motor function, body temperature, neuroendocrine activity, mood, emotion, and, memory. All these functions may be affected by cerebral ischemia. Besides, $5-\mathrm{HT}_{1 \mathrm{~A}}$ receptors have been a target for neuroprotection in animal models of cerebral ischemia. However, indiscriminate activation of pre and postsynaptic by $5-\mathrm{HT}_{1 \mathrm{~A}}$ receptor agonists may produce no therapeutic benefits in patients. The lack of receptor discrimination may be a limiting factor in the therapeutic efficacy of the agonists because $5-\mathrm{HT}_{1 \mathrm{~A}}$ receptors in different brain regions can mediate diverging or even contradictory responses. In this review, we present experimental evidence that $5-\mathrm{HT}_{1 \mathrm{~A}}$ receptor agonists can prevent neuronal damage and promote functional recovery induced by focal or transient global ischemia in rodents. We also disucss the biased $5-\mathrm{HT}_{1 \mathrm{~A}}$ agonis NLX101 (also known as F15599), a compound that preferentially and potently stimulates postsynaptic cortical pyramidal neurons without inhibiting serotonin neuron firing (Newman-Tancredi et al., 2009; Llado-Pelfort et al., 2010). 


\section{Serotonin and serotonin receptors}

Serotonin or 5-hydroxytryptamine $(5-\mathrm{HT})$ is a monoamine which is widely distributed in the central nervous system. As a neurotransmitter, $5-\mathrm{HT}$ is involved in almost every brain's physiological function and plays essential roles in hormonal control, sleep, body temperature, appetite, mood, motor activity, and cognition (Feijó et al., 2010; David and Gardier, 2016; Haleem, 2019).

Serotonergic neurons arise from the brainstem raphe nuclei, i.e., the dorsal raphe nucleus (DRN), median raphe nucleus (MRN), and caudal raphe nucleus (CRN) (Bang et al., 2012). The DRN and MRN project serotonergic fibers through the medial forebrain bundle (MFB) to frontal areas, while the CRN innervates cerebellar and spinal targets (Jacobs and Azmitia, 1992; Gaspar and Lillesaar, 2012; Maddaloni et al., 2017). Most of the projections that reach the DRN come from the hypothalamus, medulla, cortex, and amygdala. The MRN receives projections from the amygdala, prefrontal cortex (PFC), and other cortical areas, and mainly from the hypothalamus and midbrain (Pollak Dorocic et al., 2014).

5-HT is synthesized in two steps from the essential amino acid L-tryptophan acquired from the diet (Fig. 1). Tryptophan is hydroxylated at position 5 to 5 -hydroxytryptophan by tryptophan hydroxylase (TPH) is the rate-limiting enzyme, and then decarboxylated by the amino acid L-amino-aromatic enzyme, to 5-HT (Walther et al., 2003). Two TPH isoforms have been identified: TPH1 which is expressed in non-neuronal cells such as enterochromaffin and mast cells (Fitzpatrick, 1999), and the TPH2 isoform which is expressed in the raphe nuclei and myenteric plexus (Walther et al., 2003). After synthesis, 
5-HT storage occurs in vesicles present in presynaptic neurons. Once released in the synaptic cleft, 5-HT may act on pre-or postsynaptic serotonergic receptors. Subsequently, $5-\mathrm{HT}$ is taken up through the serotonin transporter (SERT), into presynaptic neurons where it undergoes a degradation process by the monoamine oxidase enzyme (MAO) generating the 5-hydroxy indole acetic metabolite (5-HIAA) (David and Gardier, 2016). In addition to its release in projection areas, vesicular $5-\mathrm{HT}$ release occurs locally in the DRN at somatic (Colgan et al., 2009), dendritic (de Kock et al., 2006; Colgan et al., 2012), and axonal sites (Bruns et al., 2000), where it modulates the activity of DRN neurons (Figure 2). Ultrastructural studies have found somatodendritic receptors at extrasynaptic sites where serotonergic transmission occurs by paracrine activation by low concentrations of transmitter out from synapses, i.e., via volume transmission (Bunin and Wigthman, 1999; Courtney and Ford, 2015).

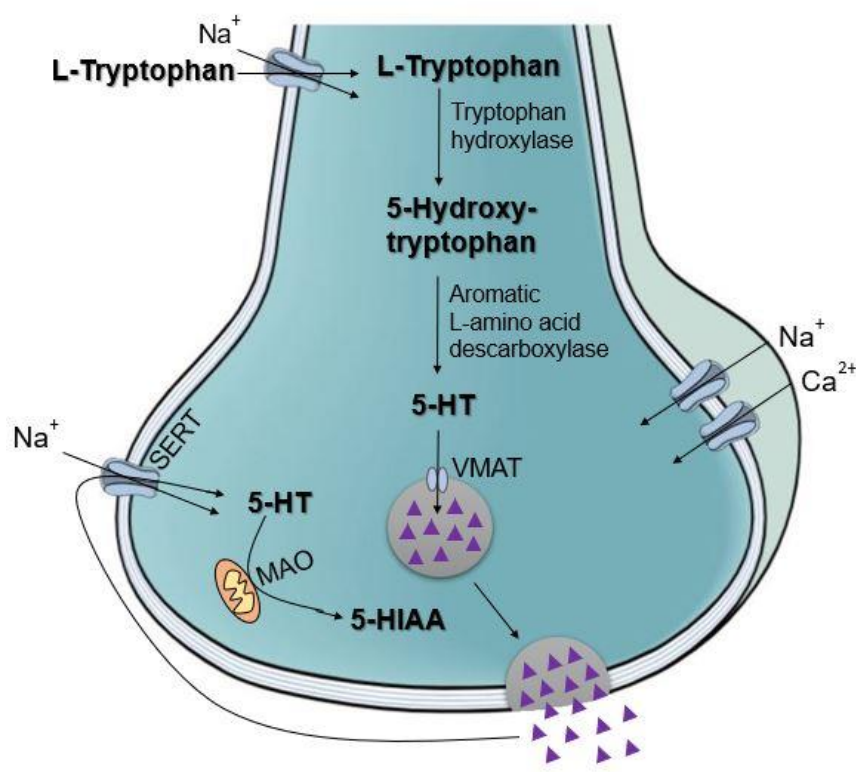

Figure 1: Synthesis and release of serotonin (5-HT). 5-HT: hydroxytryptamine; VMAT: vesicular monoamine transporter; 5-HIAA: 5-hydroxy indole acetic acid; MAO: monoamine oxidase; SERT: serotonin transporter. 
Serotonergic receptors are proteins that are bound to membranes and grouped into families according to their associated system of second messengers, their amino acid sequence, or their functional homology. The functional responses to 5-HT are mediated by 7 different families of receptors, designated $5-\mathrm{HT}_{1}$ to $5-\mathrm{HT}_{7}$, which are further divided into 15 subtypes (Hoyer et al., 1994; Bockaert et al., 2010; Hanon et al., 2008; Table 1). Except for the $5-\mathrm{HT}_{3}$ ionotropic receptor, all other 5-HT receptors are classical metabotropic G-protein coupled receptors (GPCR) which couple to canonical signaling pathways through $\mathrm{G} \alpha \mathrm{i}, \mathrm{G} \alpha \mathrm{s}$, and $\mathrm{G} \alpha \mathrm{q} / 11$ and elicit the expected second messenger cascades (Nichols and Nichols, 2008). The Gai-coupled serotonin receptors encompass the $5-\mathrm{HT}_{1}$ and $5-\mathrm{HT}_{5}$ types, leading to inhibition of adenylyl cyclase (AC) and a consequent decrease of cyclic adenosine monophosphate (cAMP) levels (Lin et al., 2002). The $\mathrm{G} \alpha \mathrm{q} / 11$-coupled serotonin receptors include the $5-\mathrm{HT}_{2}$ receptor subtypes, which are linked to activation of phospholipase C (PLC), producing inositol trisphosphate (IP3) and diacylglycerol (DAG), ultimately leading to an increase in intracellular calcium $\left(\mathrm{Ca}^{++}\right)$(Roth et al., 1998). 5- $\mathrm{HT}_{4}, 5-\mathrm{HT}_{6}$, and $5-\mathrm{HT}_{7}$ coupled to the stimulatory G protein $(\mathrm{G} \alpha \mathrm{s})$ and stimulate $\mathrm{AC}$ and protein kinase A (PKA), leading to increased levels of cAMP (Polter and Li, 2010) (Table 1). Metabotropic 5-HT receptor function may also elicit noncanonical signals that can be either mediated by a host of alternative G-proteins or be Gprotein-independent. G-protein independent signaling may involve $\beta$-arrestins which are associated with other signaling pathways such as the mitogen-activated protein kinases including extracellular signal-regulated kinase (ERK) (Schmid et al., 2008; McCorvy and Roth, 2015), although these can also be activated via G-protein mediated mechanisms. 
Arrestin has been associated with GPCR desensitization (Freedman and Lefkowitz, 1996) and internalization (Ferguson et al., 1996), indicating the clinical importance of this signaling pathway to tolerance development and therapeutic efficacy of drugs (Violin et al., 2014).

Table 1: Serotonin receptor types, subtypes, and signaling mechanisms in the CNS

\begin{tabular}{|c|c|c|c|c|c|}
\hline Receptor & Subtypes & Locations & $\begin{array}{l}\text { Signaling } \\
\text { mechanism }\end{array}$ & $\begin{array}{l}\text { Cellular } \\
\text { response }\end{array}$ & References \\
\hline $5-\mathrm{HT}_{1}$ & $\begin{array}{l}1 \mathrm{~A}, 1 \mathrm{~B}, 1 \mathrm{C} \\
1 \mathrm{D}, 1 \mathrm{E}, 1 \mathrm{~F}\end{array}$ & $\begin{array}{c}\text { raphe, } \\
\text { hippocampus, } \\
\text { córtex, striatum, } \\
\text { amygdala, } \\
\text { hypotalamus }\end{array}$ & $\begin{array}{c}\text { Goilo; } \mathrm{AC}, \mathrm{PKA}, \downarrow \\
\text { cAMP }\end{array}$ & Inhibitory & $\begin{array}{l}\text { De Vivo and } \\
\text { Maayani, } \\
\text { 1986; Albert et } \\
\text { al., 1990; Liu } \\
\text { and Albert, } \\
\text { 1991; Albert } \\
\text { and Vahid- } \\
\text { Ansari, } 2019\end{array}$ \\
\hline $5-\mathrm{HT}_{2}$ & $2 \mathrm{~A}, 2 \mathrm{~B}, 2 \mathrm{C}$ & $\begin{array}{c}\text { raphe, } \\
\text { hippocampus, } \\
\text { córtex, striatum, } \\
\text { amygdala, } \\
\text { hypotalamus }\end{array}$ & $\begin{array}{c}\mathrm{G} \alpha q ; \mathrm{PLC}, \uparrow \mathrm{IP} 3 \\
\text { and DAG }\end{array}$ & Excitatory & $\begin{array}{c}\text { Roth et al., } \\
\text { 1998; Xu and } \\
\text { Pandey et al., } \\
2000\end{array}$ \\
\hline $5-\mathrm{HT}_{3}$ & $3 \mathrm{~A}, 3 \mathrm{~B}$ & $\begin{array}{l}\text { hippocampus, } \\
\text { córtex, striatum, } \\
\text { amygdala, dorsal } \\
\text { vagal complex }\end{array}$ & $\mathrm{Na}^{+}, \mathrm{K}^{+}$ion channe & Excitatory & $\begin{array}{l}\text { Pratt et al., } \\
\text { 1990; } \\
\text { Chameau and } \\
\text { Hooft, } 2006\end{array}$ \\
\hline $5-\mathrm{HT}_{4}$ & & $\begin{array}{c}\text { hippocampus, } \\
\text { córtex, striatum, } \\
\text { amygdala, basal } \\
\text { ganglia }\end{array}$ & $\begin{array}{c}\mathrm{G} \alpha s ; \mathrm{AC}, \mathrm{PKA}, \uparrow \\
\mathrm{cAMP}\end{array}$ & Excitatory & $\begin{array}{c}\text { Eglen et al., } \\
\text { 1995; } \\
\text { Bockaert et } \\
\text { al., } 2004\end{array}$ \\
\hline $5-\mathrm{HT}_{5}$ & & raphe & Gailo, $\downarrow$ cAMP & Inhibitory & Nelson, 2004; \\
\hline $5-\mathrm{HT}_{6}$ & & $\begin{array}{l}\text { hippocampus, } \\
\text { córtex, striatum, }\end{array}$ & $\begin{array}{c}\mathrm{G} \alpha s ; \mathrm{AC}, \mathrm{PKA}, \uparrow \\
\mathrm{cAMP}\end{array}$ & Excitatory & $\begin{array}{c}\text { Woolley et al., } \\
2004 ;\end{array}$ \\
\hline
\end{tabular}




\begin{tabular}{|c|c|c|c|c|c|}
\hline & & $\begin{array}{c}\text { amygdala, basal } \\
\text { ganglia }\end{array}$ & & & $\begin{array}{c}\text { Condony et } \\
\text { al., } 2010\end{array}$ \\
\hline 5-HT & & Hippocampus, & G $\alpha$ s; AC, PKA, $\uparrow$ & Excitatory & Thomas and \\
& & Suprachiasmatic & cAMP & & Hagan, 2004; \\
& & nucleus & & & Gellynck et \\
& & & & & al., 2013 \\
\hline
\end{tabular}

AC, adenylate cyclase; cAMP, cyclic Adenosine Monophosphate; DAG, Diacylglycerol; IP3, inositol trisphosphate; PKA protein kinase A; PLC, phospholipase C.

\section{The $5-\mathrm{HT}_{1 \mathrm{~A}}$ receptor}

The $5-\mathrm{HT}_{1}$ receptor family is divided into 6 subtypes: $A, B, C, D, E$, and $F$ (Peroutka 1988). Among all the subtypes, the $5-\mathrm{HT}_{1 \mathrm{~A}}$ receptor is most studied and characterized because of its involvement in the pathophysiology and treatment of several psychiatric and neurological conditions such as anxiety, depression, Parkinson's disease, and Alzheimer's disease (Pazos et al., 1985; Celada et al., 2013; Garcia-Garcia et al., 2014; Albert and Vahid-Ansari, 2018). The induction of adult neurogenesis by antidepressants and remodeling of corticolimbic circuits has also been related to the stimulation of $5-\mathrm{HT}_{1 \mathrm{~A}}$ receptors (Santarelli et a., 2003). Moreover, novel antidepressants and antipsychotics have begun to incorporate $5-\mathrm{HT}_{1 \mathrm{~A}}$ agonist activity to enhance their therapeutic efficacy. Clozapine and the more recent antipsychotics aripiprazole, brexpiprazole, perospirone, and cariprazine, for example, exhibit partial agonist properties at 5- $\mathrm{HT}_{1 \mathrm{~A}}$ receptors and may alleviate a deficiency in dopaminergic transmission in frontocortical regions of schizophrenic patients, thus improving negative and cognitive symptoms. Further, $5-\mathrm{HT}_{1 \mathrm{~A}}$ receptor activation has been shown to reduce extrapyramidal symptoms induced by neuroleptics (for review see Newman-Tancredi and Kleven, 2011; Celada et al., 2013).

5- $\mathrm{HT}_{1 \mathrm{~A}}$ receptors can be classified into two distinct populations: presynaptic autoreceptors, located in the soma and dendrites of serotonergic neurons in the raphe 
nuclei, and postsynaptic heteroreceptors, which exist in dendrites and cell bodies of target non-5-HT neurons in 5-HT projecting areas (Verge et al., 1985; Riad et al., 2000; Palacios, 2016; Figure 2). At a presynaptic level, 5- $\mathrm{HT}_{1 \mathrm{~A}}$ receptor activation reduces the firing rate of raphe nuclei neurons, with a consequent decrease in the extracellular levels of $5-\mathrm{HT}$ in its projection areas (Wang and Aghajanian 1977; Verge et al., 1985; Sprouse and Aghajanian, 1986; Meller et al., 1990; Hjorth and Sharp 1991). 5-HT1A heteroreceptors are located in non-serotonergic neurons, primarily in limbic areas such as the PFC, amygdala, septum, and hippocampus (Albert and Vahid-Ansari, 2018). In these areas, 5$\mathrm{HT}_{1 \mathrm{~A}}$ receptors are expressed in the dendrites and soma of glutamatergic pyramidal neurons (Riad et al., 2000) and, axon terminals of GABAergic (Freund et al., 1990; Halasy et al., 1992) and cholinergic neurons (Cassel and Jeltsch, 1995) which makes difficult to predict the effects of 5- $\mathrm{HT}_{1 \mathrm{~A}}$ activation on the pattern of neuronal firing (Albert and VahidAnsari, 2019). Typically, activation of heteroreceptors on distinct neurons reduces neuronal excitability and firing (Polter and $\mathrm{Li}, 2010$ ). Finally, the presence of $5-\mathrm{HT}_{1 \mathrm{~A}}$ receptors has been demonstrated in the cell body and processes of astrocytes (WhitakerAzmitia et al., 1993). 5-HT 1 A expression in astrocytes was related to neuroprotective effects in Parkinsonian mice (Miyazaki et al., 2013; Miyzaki and Asanuma, 2016) and gerbils with cerebral ischemia (Lee et al., 2014) by promoting astrocyte proliferation and upregulation of antioxidative molecules. 


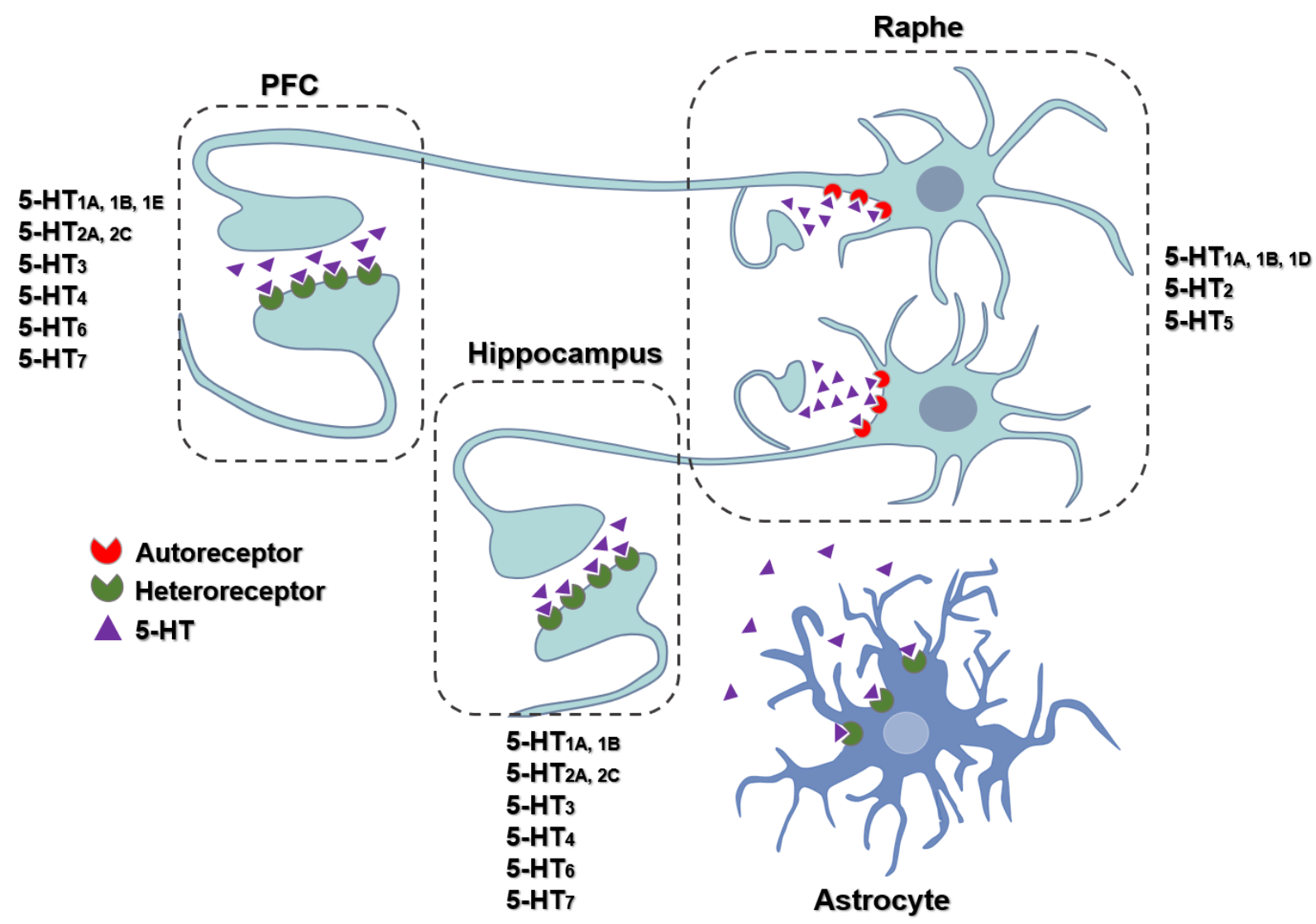

Figure 2: Distribution of the 5-HT receptors in the central nervous system.

Multiple $5-\mathrm{HT}_{1 \mathrm{~A}}$ receptor signaling pathways have been identified in heterologous systems, but only a few of these pathways have been studied in neuronal systems. In general, the primary coupling linkage of the $5-\mathrm{HT}_{1 \mathrm{~A}}$ receptor is linked via $\mathrm{G} \alpha \mathrm{i} / \mathrm{G} \alpha \mathrm{o}$ to the inhibition of $A C$ and a decrease in PKA activity (Figure 3). $5-\mathrm{HT}_{1 \mathrm{~A}}$ receptors also couple to ion channels, via $\mathrm{G} \beta / \gamma$ subunits, activating inward rectifying potassium channel (GIRK) to hyperpolarize membrane potential and inhibit voltage-dependent $\mathrm{Ca}^{++}$channels (VDCC) (Figure 3) (Raymond et al., 1999; Albert and Vahid-Ansari, 2018). For other 5$\mathrm{HT}_{1 \mathrm{~A}}$ receptor-G protein interactions, the $\mathrm{G} \beta / \gamma$ complex is always released, which in turn can activate multiple effectors including the phosphorylated mitogen-activated protein 
kinase (MAPK), ERK1/2 and also PI3-kinase(PI3K)-Akt-GSK3 $\beta$ signaling pathways (Della Rocca et al., 1999). Differences in 5-HT 1 A autoreceptor and heteroreceptor coupling to $\mathrm{G}$ proteins are believed to underlie different signaling and desensitization (Haleem, 2019). The autoreceptors are reported to mainly couple with $\mathrm{G} \alpha i$ while heteroreceptors are preferentially coupled to $\mathrm{G} \alpha o$ in the hippocampus and with both $\mathrm{G} \alpha o$ and $\mathrm{G} \alpha \mathrm{i}$ in the cortex (La Cour, 2006). Therefore, the signaling pathway associated with the $5-\mathrm{HT}_{1 \mathrm{~A}}$ receptor is probably determined by the precise signaling environment existing in a particular cell, even though the presence of other $G$ proteins may redirect signal transduction to other existing pathways (Rojas and Fiedler, 2016).

A major pathway of the $5-\mathrm{HT}_{1 \mathrm{~A}}$ receptor coupled to $\mathrm{G} \beta / \gamma$ complex is the $\mathrm{ERK} 1 / 2$, pathway mediated by phosphorylated MAPK/ERK kinase. Hydrolysis of MAPK precedes the stimulation of the critical enzymes ERK1/2, which activates the transcription factor of the cAMP-responsive binding protein (CREB). CREB has been shown to regulate neuronal proliferation and survival, neurogenesis, and dendritic remodeling (Carlezon et al., 2005; Blendy, 2006). 5-HT $1 \mathrm{~A}$ receptor coupling to ERK1/2 is observed in the hippocampal-derived cell lines with endogenous expression of 5-HT ${ }_{1 \mathrm{~A}}$ receptors (Adayev et al., 1999) as well as in hippocampal tissue (Mehta et al., 2007). The 5$\mathrm{HT}_{1 \mathrm{~A}} / \mathrm{CREB} / \mathrm{ERK} 1 / 2$ pathway seems to be important for neuronal protection (Albert and Vahid-Ansari, 2019). Direct stimulation of 5-HT1A receptor caused elevation in the expression of postsynaptic density protein (PSD)-95 and dendritic spine and synapse formation throughout sequential activation of MAPK isoenzymes ERK1/2 and protein kinase $\mathrm{C}$ alpha $(\mathrm{PKC} \alpha)$ in both a mouse neuron-derived cell line (HN2-5) and in organotypic hippocampal slice cultures from postnatal day 15 (P15) mice (Debata et al., 
2010). The same pathway PKCa/ERK1/2 augmented PSD-95 and synaptogenesis in the hippocampus of in vivo mice (Moghda et al., 2012). These findings indicated that PKCa constitutes a direct substrate of ERK1/2 in neuronal cells and might have a role in the neuroprotection of hippocampal neurons (Mogha et al., 2012). However, the effects of 5$\mathrm{HT}_{1 \mathrm{~A}}$ receptor activation of ERK on neurons vary and appear to depend on their location in different brain regions. For example, $5-\mathrm{HT}_{1 \mathrm{~A}}$ receptor activation inhibits ERK1/2 phosphorylation in RN46A cells, a model of serotonergic raphe nucleus neurons that express endogenous 5- $\mathrm{HT}_{1 \mathrm{~A}}$ receptors (Kushwaha \& Albert, 2005). Besides, endogenous $5-\mathrm{HT}_{1 \mathrm{~A}}$ receptors did not couple to activation of ERK1/2 in primary cultures of rat hippocampal neurons (Cowen et al., 2005).

The PI3K/Akt pathway has been found to confer neuroprotection by inhibiting apoptosis in several experimental conditions (Tamatani et al., 1998; Matsuzaki et al., 1999; Yamaguchi et al., 2001). Activation of PI3K/Akt pathway by $5-\mathrm{HT}_{1 \mathrm{~A}}$ receptor resulted in translocation of the nuclear transcription factor-kB (NF-kB) which was required for inhibiting caspase 3 activation in transfected Chinese hamster ovary cells (Hsiung et al., 2005). The PI3-K/Akt pathway has been implicated in the regulation of cell growth, survival, and proliferation as well as in synaptic plasticity (Kim et al., 2004). However, the exact mechanism of how $5-\mathrm{HT}_{1 \mathrm{~A}}$ receptors couple to the $\mathrm{PI} 3 \mathrm{~K}$ pathway in neurons is still unclear (Albert and Vahid-Ansari, 2019).

The signaling pathways associated with $5-\mathrm{HT}_{1 \mathrm{~A}}$ receptors are probably determined by the precise $\mathrm{G} \alpha i / \mathrm{G} \alpha o$ isoform existing in cells and cascades involving $\mathrm{G} \beta / \gamma$ signaling. 5$\mathrm{HT}_{1 \mathrm{~A}}$ receptor activation may impact neuronal plasticity and decrease neurodegeneration likely by modulation of MAPK/ERK and PI3K/Akt signaling pathways (Chilmonczyk et al., 
2015; Rojas and Fiedler, 2016; Albert and Vahid-Ansari, 2019; Sharp and Barnes, 2020).

Of note, those signaling pathways have been suggested to be involved in neuroprotective mechanisms including the stimulation of nuclear factor-kB (NF-kB), inhibition of caspase 3 , and increasing the expression of the antiapoptotic protein Bcl-2 (Chilmonczyk et al., 2015).

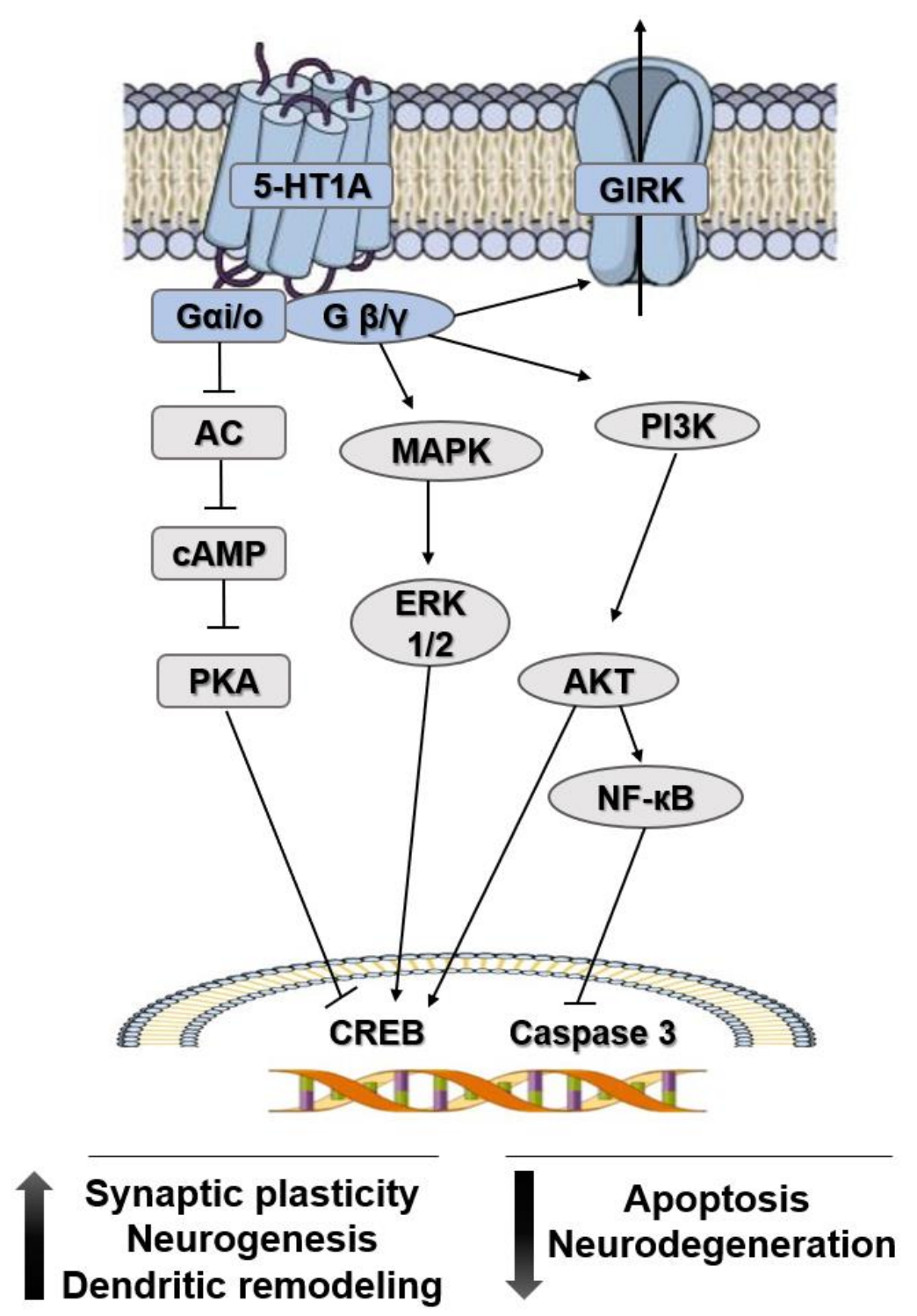

Figure 3: Signaling transduction pathways linked to 5- $\mathrm{HT}_{1 \mathrm{~A}}$ autoreceptors and/or postsynaptic heteroreceptors. 


\section{4. $5-\mathrm{HT}_{1 \mathrm{~A}}$ receptors as a potential target for neuroprotection in cerebral ischemia}

\subsection{Cerebral ischemia}

Cerebral ischemia is one of the principal causes of death and disability worldwide and represents an increased economic burden due to treatment and post-ischemia care (Chamorro et al., 2016; Benjamin et al., 2018; Rajsic et al., 2019; Johnson et al., 2019). Cerebral ischemia occurs as a result of the transient or permanent reduction in the cerebral blood flow (CBF) in restricted brain regions (focal cerebral ischemia or stroke) or the whole brain (global cerebral ischemia). Focal cerebral ischemia (FCI) has been categorized as either ischemic or hemorrhagic. Ischemic stroke is caused by the interruption of $\mathrm{CBF}$ to the brain due to a thrombotic or embolic occlusion in a particular cerebral artery. Hemorrhagic strokes occur within the brain ruptures. Globally, ischemic stroke accounts for $87 \%$ of stroke cases and it is the third most frequent cause of death for people over 60 years old in developed countries. Hemorrhagic stroke accounts for the remaining $13 \%$ of patients (Chamorro et al., 2016; Johnson et al., 2019).

Prolonged circulatory deficits may induce dramatic neuronal damage, leading to a broad range of neuropsychological and behavioral dysfunctions, such as motor impairments, cognitive deficits, and emotional symptoms (Anderson and Arciniegas, 2010). Motor deficits are the most common symptom after stroke and are present in up to $77 \%$ of the patients (Lawrence et al., 2001). Studies on cognitive impairment after cerebral ischemia have reported rates ranging from 35\% to $87 \%$ (Hoffmann et al., 2009; Van Rooij et al., 2016; Delavaran et al., 2017). Anxiety and post-stroke depression range from $29 \%$ to $52 \%$ (Ayerbe et al., 2013; Hackett et al., 2014; Knapp et al., 2017). The 
neuropsychiatric sequelae of cerebral ischemia are disabling and can have a negative influence on recovery, reduce the quality of life, and lead to exhaustion of the caregivers.

In general, stroke is characterized by an infarcted core, where cell death occurs within minutes after arterial occlusion and the peri-infarcted region surrounding the infarction named penumbra where there is a partial reduction in blood supply; this region represents an area to which therapeutic neuroprotective interventions can be directed (Povroznik et al., 2019). The nature and severity of $\mathrm{FCl}$ consequences depend mainly on the location and extent of the injury (Dugue et al., 2017).

Experimentally, $\mathrm{FCl}$ can be modeled through transient or permanent occlusion of the middle cerebral artery (MCA) in mice or rats. MCA occlusion (MCAo) models have been used extensively because they reproduce the pattern of ischemic cerebral damage and the functional disabilities such as neurological deficits, including sensorimotor changes which are also often observed in many human stroke patients (Traytsman, 2003; Hermann et al., 2019). In general, MCAo results in a significant reduction of CBF in both striatum and cortex. However, the degree and distribution of blood flow reduction depend on the duration of MCAo, the site of occlusion along with the MCA, and the amount of collateral blood flow into the MCA territory (Traystman, 2003; Gennaro et al., 2019). These factors determine the size of the lesion. Considerable variability in the extension of infarct size and behavioral outcomes have been recurrent findings with this model and compromised in part its potential in preclinical studies (Bardutzky et al., 2005; Senda et al., 2005).

Transient global cerebral ischemia (TGCl) results from unexpected reversible cardiac arrest, severe respiratory arrest, gas poisoning, perinatal asphyxia, and diagnostic and 
surgical procedures. Patients that survive TGCI may experience a wide range of longterm dysfunctions, the most prominent of which are cognitive deficits, attention deficits, verbal communication deficiency, spatial/temporal disorientation, impaired decisionmaking, anxiety, and depression (Anderson and Arciniegas, 2010). TGCI can be modeled through bilateral typical carotid artery occlusion (BCCAO) in mice and Mongolian gerbils and via two vessels (2-VO) or four-vessel occlusion (4-VO) in rats (León-Moreno et al., 2020). Usually, TGCl affects areas of the forebrain, such as the highly vulnerable hippocampal pyramidal neurons (CA1 and CA3 regions), the medium-sized dorsoventral striatum neurons, and the pyramidal neurons in the PFC (Raval et al., 2009; Li et al., 2011; Khodanovich and Kisel, 2015). This leads to the loss or severe impairment of brain functions that include motor coordination, grip strength, and cognitive and memory abilities. As for MCAo models, the degree of damage to the brain areas will decide the fate of brain functioning (Knowles et al., 2016).

\subsection{Pathophysiology of cerebral ischemia}

The pathophysiological mechanisms that eventually lead to the degeneration of cerebral tissue due to FCl or TGCl seem to be similar (Dirnagl, 1999; Leker and Shohami, 2002; Mehta et al., 2007; Chamorro et al., 2016; Anrather and ladecola, 2016). They comprise a multitude of pathways, often interconnected and overlapped, that operate at different time points and locations in the extra- and intracellular milieu. The chain of processes begins with the breakdown of ion homeostasis in the neuronal membrane, particularly the failure of the $\mathrm{Na}^{+} / \mathrm{K}^{+}$-adenosine triphosphate pump caused by the energetic collapse. Anoxic depolarization, together with the massive release of glutamate 
by presynaptic terminals, then occurs. Glutamate stimulates N-methyl-D-aspartate (NMDA) and a -amino-3-hydroxy-5-methyl-4-isoxazole propionic acid (AMPA) receptors. It promotes the continuous influx of $\mathrm{Ca}^{++}$, which in turn activates a series of enzymes and increases oxidative stress in the adjacent postsynaptic cells. These changes occur within minutes and comprise the excitotoxic phase of brain ischemia, with necrotic cell death in the infarcted core. An endogenous protective mechanism against the excess of membrane depolarization that is initiated by reduced energy stores is mediated by the ATP-sensitive $\mathrm{K}^{+}$channel. Usually closed in normal conditions, this channel is activated rapidly under cerebral ischemic conditions, causing $\mathrm{K}^{+}$efflux, limiting neuronal excitability and $\mathrm{Ca}^{++}$influx, and thus blocking the subsequent neurotoxic biochemical cascade (Liao et al., 2010). Oxidative and nitrosative stress are partly consequences of excitotoxicity and result from an increase in secondary messenger systems coupled to the enzymatic generation of reactive oxygen species (ROS) including superoxide anions, hydrogen peroxide, hydroxyl radicals, and peroxynitrite (Fukuyama et al., 1998). ROS and reactive nitrogen species are shown to act directly as executioners of neuronal cell death during cerebral ischemia (Chan, 2001).

Robust sterile neuroinflammation starts a few hours after the onset of cerebral ischemia and is characterized by blood-brain barrier (BBB) disruption, infiltration of peripheral leukocytes, activation of microglia and astrocytes, and the release of molecules known as damage-associated molecular patterns (DAMPs) by injured and dying cells (Liesz and Kleinschnitz, 2016). Activated immune cells triggered by DAMPs produce inflammatory cytokines, chemokines, and other cytotoxic mediators, leading to exacerbation of cerebral ischemic injury (Gelderblom et al., 2009; Kleinig and Vink, 2009; Chen Nunez, 2010). The 
first immune cell to respond to ischemic injury is brain-intrinsic microglia, followed by astrocytes and neutrophils that exacerbate oxidative stress and BBB damage (Justicia et al., 2003). Monocytes, monocyte-derived macrophages, dendritic cells, natural killer cells, and lymphocytes regulate post-ischemic inflammation and may have beneficial or detrimental roles on cerebral injury (Liesz and Kleinschnitz, 2016).

Concomitantly to all neurodegenerative processes, at a particular time point after cerebral ischemia, protective and repair mechanisms such as an increase in the expression of anti-inflammatory mediators and neurotrophic factors and, reactive angiogenesis and neurogenesis take place (Ding et al., 2008; Dirnagl, 2012; Rajkovic et al., 2018). In particular, the cAMP/PKA/pCREB pathway which is closely linked to synaptic plasticity, neurogenesis, and axon growth has been considered a fundamental process that is involved in the recovery of neural function following cerebral ischemic injury (Kitagawa 2007; Sasaki et al., 2007; Zhao et al., 2015). In vitro and in vivo experiments have demonstrated that the cAMP/PKA/CREB signaling pathway and the downstream CREB effector brain-derived neurotrophic factor (BDNF) can exert neuroprotective effects in ischemic brain injury. CREB expression is upregulated in the brain after MCAo (Salminen et al., 1995), transient global cerebral ischemia (Soares et al., 2016; Mori et al., 2017), and hypoxia-ischemic (HI) injury (Zaitseva et al. 2005; Carloni et al., 2010). Intraventricular administration of BDNF attenuated hippocampal damage after global forebrain ischemia (Beck et al., 1994; Wu and Pardridge, 1999) and reduced infarct size after MCAo (Schabitz et al., 1997) in rats. Besides, the selective serotonin reuptake inhibitors fluoxetine (Kim et al., 2007) and escitalopram (Lee et al., 2011) protected against neuronal damage after transient global brain ischemia in rats, an effect that was 
related to the upregulation of BDNF expression. Conversely, a reduction in the BDNF levels in the hippocampus of ischemic mice has been associated with depressive-like behavior induced by cerebral ischemia (Kim et al., 2016; Pang et al., 2015).

\section{Pharmacotherapy for cerebral ischemia}

The primary purpose of neuroprotective pharmacotherapy is to reduce the severity of initial damage and improve functional outcome weeks and months after a cerebral ischemic event. However, advances in pharmacotherapy to cerebral ischemia have been limited. The thrombolytic agent recombinant tissue plasminogen activator (rtPA) is the only FDA-approved therapy for stroke. However, the narrow time window of treatment (within $4.5 \mathrm{~h}$ of the ischemic event) and the possible occurrence of hemorrhage limits its applicability to a minority of patients (The National Institute of Neurological Disorders and Stroke rtPA Stroke Study Group, 1995). Moreover, reperfusion itself is associated with further neuronal damage by activation neuroinflammatory response, thus causing tissue injury (Dhir et al., 2020). Antiplatelet drugs, anticoagulants, and statins act as prophylactics and have no immediate effect following an acute ischemic attack (Tajiri et al., 2013). Therefore, there is a substantial need for neuroprotective strategies to prevent neuronal damage and promote functional recovery after cerebral ischemia.

6. Experimental evidence and putative mechanisms underlying the neuroprotective effects of $5-\mathrm{HT}_{1 \mathrm{~A}}$ receptor agonists in experimental cerebral ischemia 


\subsection{5-HT $1 \mathrm{~A}$ agonists and MCAO models}

Studies on the involvement of the $5-\mathrm{HT}_{1 \mathrm{~A}}$ receptor in cerebral ischemia advanced from the 1990s onwards after the development of selective $5-\mathrm{HT}_{1 \mathrm{~A}}$ receptor agonists. Bielenberg and Burkhardt (1990) have shown the effects of acute treatment with various 5- $\mathrm{HT}_{1 \mathrm{~A}}$ receptor agonists, including the full agonists 8-OH-DPAT and BayR 1531, or partial agonists as buspirone, gepirone, and ipsapirone, in mice and rats subjected to permanent MCAo (Table 2). In general, the drugs administered 30 min before or 60 min after MCAo and caused a significant reduction in the infarct volume in the cerebral cortex. Ipsapirone and Bay R 1531 reduced cortical infarct size by more than $60 \%$ as compared to controls.

Neuroprotective effects have also been shown with partial agonists including CM 57943, urapidil, S1467,1 and ipsapirone in rodents subjected to MCAo (Prehn et al., 1991; 1993; Kamei et al., 2001; Johansen et al., 2014). Both 5-HT 1 A agonists CM 57943 and urapidil promoted a decrease in the size of infarct in the cerebral cortex of ischemic rodents (Table 2). Moreover, these 5-HT1A agonists were able to reduce neuronal damage of cultured neocortical and hippocampal neurons subjected to chemical hypoxia or glutamate overload in a dose-dependent manner (Prehn et al., 1993). Similarly, the potent

5- $\mathrm{HT}_{1 \mathrm{~A}} \quad$ agonist, $\quad$ compound $26 \quad$ (2-\{6-[(3,4-dihydro-2chromeen-2ylmethyl)amino]hexyl\}tetrahydro-1H-pyrrolo[1,2c] imidazole-1,3(2H)-dione), has produced neuroprotective effects in both in vitro assays using primary cell cultures from rat hippocampus as well as in rats with MCAo (Table 1) (Marco et al., 2011). Repinotan was also effective in decreasing the infarct size when administered $4 \mathrm{~h}$ after MCAo (Semkova et al., 1998; Mauler and Horvat, 2005). 
In another study, Kamei et al. (2001) have demonstrated the neuroprotective effects of buspirone and compound 5 (SUN N 4057) in rats subjected to MCAo. In this study, the measurement of peripheral type benzodiazepine binding sites (PTBBS) in ipsilateral cortical and striatal homogenates was carried out as an index for quantification of neuronal damage 10 days after cerebral ischemia. A single administration of compound 5 exerted a dose-dependent reduction of PTBBS levels and reduced the ischemic hyperthermia at neuroprotective doses.

Extensive preclinical studies have been done with the full $5-\mathrm{HT}_{1 \mathrm{~A}}$ receptor agonist, repinotan (Bay X 3702) after permanent (Semkova et al., 1998) or transient (Mauler and Horvat, 2005; Kukley et al., 2001) MCAo. Repinotan, when administered immediately after reperfusion or even $5 \mathrm{~h}$ later, reduced the cortical infarction volume up to $97 \%$ in rats with MCAo. In vitro, the activity of repinotan was abolished by WAY 100635 , indicating that the effect was mediated via $5-\mathrm{HT}_{1 \mathrm{~A}}$ receptor stimulation. Also, repinotan elevated the level of the apoptosis-inhibiting protein BCL-2 in the ipsilateral cerebral cortex of ischemic animals, indicating a neuroprotective effect of repinotan treatment (Kukley et al., 2001).

The favorable neuroprotective efficacy, broad dose-response curve, and prolonged therapeutic window observed in those stroke models positioned repinotan as a promising candidate for clinical trials for treating acute ischemic stroke in humans (Berends et al., 2005). The tolerability, safety, and dose of repinotan were investigated in Phase II doubleblind, placebo-controlled study in which 240 patients with acute hemispheric ischemia (focal ischemia) received placebo or repinotan at $0.5,1.25$ or $2.5 \mathrm{mg} / \mathrm{kg}$ given by i.v. infusion during $72 \mathrm{~h}$. Treatment was started within $6 \mathrm{~h}$ of symptoms onset and evaluations were performed at one and 3 months later. Although both doses of $0.5 \mathrm{mg} / \mathrm{kg} / \mathrm{day}$ and 
$1.25 \mathrm{mg} / \mathrm{kg} /$ day were well tolerated with few patients requiring discontinuation, a higher incidence of serotonergic adverse side effects including shivering, heavy sweating, restlessness, agitation and confusion was detected in the $2.5 \mathrm{mg} / \mathrm{kg} /$ day dosage group (Teal et al., 2005). To optimize repinotan exposure of patients with stroke, a Randomized Exposure Controlled Trial (RECT) was design for a Phase IIB study with repinotan (Teal et al., 2009). Several changes were implemented after the randomization of 98 patients into RECT and included: i) reduction of the allowed treatment time window from 6 to 4.5 $\mathrm{h}$ to increase the potential for neuroprotective effect; ii) a loading dose to reach target plasma concentrations sooner; and iii) patient assignment in a 1:1 ratio to treatment with repinotan or placebo (changed from 2:1 in RECT). However, this study failed to demonstrate a clinical benefit of repinotan and the development of repinotan in ischemic stroke was discontinued (Teal et al, 2009).

Finally, other preclinical results have supported the direct involvement of $5-\mathrm{HT}_{1 \mathrm{~A}}$ receptors in neuroprotective therapies for cerebral ischemia. In this respect, cannabidiol, which is the second most abundant Cannabis sativa derived cannabinoid, reduced the infarct volume and increased the CBF in mice with MCAo. The effect of cannabidiol was inhibited by the $5-\mathrm{HT}_{1 \mathrm{~A}}$ antagonist, WAY100635, but not by a CB1 receptor antagonist or by a vanilloid receptor antagonist (Mishima et al., 2005).

\subsection{5-HT $\mathrm{HA}_{1 \mathrm{~A}}$ receptor agonists and $\mathrm{TGCl}$ models}

Transient global cerebral ischemia is characterized by an abrupt and complete reduction of blood flow and glucose, which causes selective neuronal injury to vulnerable brain areas such as the hippocampus. As shown in Table 2, single administration of CM 
57943, urapidil, repinotan, ipsapirone and repinotan (BAY R 1531), 15 to 30 min before or immediately after 2-VO resulted in a reduction of neuronal loss in the CA1 hippocampal subarea and entorhinal cortex of rats (Prehn et al., 1991; 1993; Schaper et al., 2000). The anti-apoptotic effect of repinotan was abolished by cotreatment with the $5-\mathrm{HT}_{1 \mathrm{~A}}$ receptor antagonist WAY100635 (Schaper et al., 2000). A 7-day infusion with the 5-HT 1 A agonist, 8-OH-DPAT, prevented the neuronal loss in the hippocampal CA1 subarea induced by 2-VO in rats. Hypothermia was proposed as a possible explanation for the neuroprotective effect of 8-OH-DPAT (Torup et al., 2000).

Mongolian gerbils have unique vascular anatomy with no posterior communicating artery, which connects the carotid and vertebrobasilar arterial system. Thus, BCCAO in gerbils results in severe neurological signs and death of hippocampal CA1 neurons (Traystman, 2003). Neuroprotective effects have been detected in gerbils subjected to BCCAO and treated with 5- $\mathrm{HT}_{1 \mathrm{~A}}$ receptor agonists (Table 2). Ipsapirone, and Bay R 1531 attenuated neuronal loss in the hippocampal CA1 region in gerbils subjected to BCCAO (Bode-Greuel et al., 1990; Salazar-Colocho et al., 2007; 2008). Bay R1531 showed a powerful neuroprotective effect with $100 \%$ preservation of neurons while gepirone and 8 OH-DPAT were ineffective. Besides, Piera et al. (1995) have observed that 8-OH-DPAT, buspirone, and flesinoxan abolished the hyperactivity induced by BCCAO in gerbils. However, the authors found no correlation between the behavioral effects of those $5-\mathrm{HT}_{1 \mathrm{~A}}$ agonists and the extent of their reduction in neuronal damage: only 8-OH-DPAT reduced neuronal degeneration induced by cerebral ischemia. It was suggested that the ineffectiveness of buspirone and flesinoxan may have been related to the partial agonist activity of those compounds at the $5-\mathrm{HT}_{1 \mathrm{~A}}$ receptor. 
Salazar-Colocho et al. $(2007,2008)$ demonstrated that pretreatment with $8-\mathrm{OH}-$ DPAT increased BDNF levels and prevented the neuronal loss in the hippocampal CA1 region of gerbils with BCCAo. Also, pretreatment with 8-OH-DPAT decreased phosphorylation of NMDA receptors in the hippocampus of ischemic gerbils, attenuating neurotoxicity and neuronal loss (Tingley et al., 1997). The authors concluded that NR1 phosphorylation and BDNF accounted, at least in part, for the neuroprotective effects of pretreatment with 8-OH-DPAT.

Table 2: $5-\mathrm{HT}_{1 \mathrm{~A}}$ receptor agonists and animal models of cerebral ischemia

\begin{tabular}{|c|c|c|c|c|}
\hline \multicolumn{5}{|c|}{ MCAO } \\
\hline $\begin{array}{c}\text { Animal } \\
\text { model/specie }\end{array}$ & Treatment & Administration & $\begin{array}{l}\text { Histopathology/ } \\
\text { Functional } \\
\text { parameters } \\
\end{array}$ & Reference \\
\hline $\begin{array}{c}\text { MCAo/ } \\
\text { rats and mice }\end{array}$ & $\begin{array}{c}\text { 8-OH-DPAT } \\
(1 \mathrm{mg} / \mathrm{kg}, \text { s.c.) } \\
\text { Buspirone (10 } \\
\mathrm{mg} / \mathrm{kg}, \text { i.p.) } \\
\text { Gepirone (10 } \\
\mathrm{mg} / \mathrm{kg}, \text { i.p.) } \\
\text { Ipsapirone (10 } \\
\text { and } 30 \mathrm{mg} / \mathrm{kg} \text {, } \\
\text { i.p.) } \\
\text { Bay R } 1531 \text { (1 } \\
\text { mg/kg, i.p.) } \\
\text { Ipsapirone (30 } \\
\text { mg/kg, i.p.) }\end{array}$ & $\begin{array}{c}30 \text { min before } \\
\text { ischemia }\end{array}$ & $\begin{array}{c}\downarrow \text { size and infarct } \\
\text { volume in the cerebral } \\
\text { cortex }\end{array}$ & $\begin{array}{l}\text { Bielenberg, } \\
\text { Burkhardt, } \\
1990\end{array}$ \\
\hline $\begin{array}{l}\mathrm{MCAO} / \\
\text { rats and mice }\end{array}$ & $\begin{array}{c}\text { CM } 57943(1, \\
\text { 5, } 10 \mathrm{mg} / \mathrm{kg}, \\
\text { i.p.) } \\
\text { CM } 57943(1, \\
\text { 5, } 10 \mathrm{mg} / \mathrm{kg}, \\
\text { i.p.) } \\
\text { Urapidil (80 } \\
\text { mg/kg, i.p.) }\end{array}$ & $\begin{array}{c}30 \text { min before } \\
\text { ischemia } \\
\text { Immediately and } 60 \\
\text { min after ischemia }\end{array}$ & $\begin{array}{c}\downarrow \text { size and infarct } \\
\text { volume in the cerebral } \\
\text { cortex }\end{array}$ & $\begin{array}{c}\text { Prehn et al., } \\
1991\end{array}$ \\
\hline
\end{tabular}




\begin{tabular}{|c|c|c|c|c|}
\hline MCAo/rats & $\begin{array}{l}\text { Ipsapirone (10 } \\
\text { mg/kg, i.p.) } \\
\text { CM 57943 (10 } \\
\text { mg/kg, i.p.) } \\
\text { Urapidil (80 } \\
\text { mg/kg, i.p.) } \\
\end{array}$ & $\begin{array}{l}30 \text { min before } \\
\text { ischemia }\end{array}$ & $\begin{array}{c}\downarrow \text { size and infarct } \\
\text { volume in the cerebral } \\
\text { cortex }\end{array}$ & $\begin{array}{c}\text { Prehn et al., } \\
1993\end{array}$ \\
\hline MCAo/rats & $\begin{array}{l}\text { Repinotan (12 } \\
\text { and } 40 \\
\mu \mathrm{g} / \mathrm{kg} / \mathrm{h}, \text { i.v. })\end{array}$ & $\begin{array}{l}4 \mathrm{~h} \text { immediately after } \\
\text { ischemia }\end{array}$ & $\begin{array}{l}\downarrow \text { size and infarct } \\
\text { volume in the cerebral } \\
\text { cortex }\end{array}$ & $\begin{array}{l}\text { Semkova et } \\
\text { al., } 1998\end{array}$ \\
\hline MCAo/rats & $\begin{array}{l}\text { Repinotan (1, } \\
2 \mu \mathrm{g} / \mathrm{kg}, i . \mathrm{v})\end{array}$ & $\begin{array}{l}\text { Immediately after } \\
\text { ischemia }\end{array}$ & $\begin{array}{c}\downarrow \text { size and infarct } \\
\text { volume in the cerebral } \\
\text { cortex } \\
\uparrow \text { BCL-2 in ipsilateral } \\
\text { cortex }\end{array}$ & $\begin{array}{l}\text { Kukley et al., } \\
2001\end{array}$ \\
\hline MCAo/rats & $\begin{array}{c}\text { Buspirone (1 } \\
\mathrm{mg} / \mathrm{kg}, \text { s.c.) } \\
\text { Piclozotan } \\
(0.1,0.3,1 \\
\mathrm{mg} / \mathrm{kg}, \text { s.c. })\end{array}$ & $\begin{array}{l}\text { Immediately after } \\
\text { ischemia }\end{array}$ & $\begin{array}{l}\downarrow \text { PTBBS in cortical and } \\
\text { striatal homogenates }\end{array}$ & $\begin{array}{c}\text { Kamei et al., } \\
2001\end{array}$ \\
\hline MCAo/rats & $\begin{array}{l}\text { Repinotan (3 } \\
\mu \mathrm{g} / \mathrm{kg}, i . \mathrm{v}) \\
\text { Repinotan }(3 \\
\text { and } 10 \\
\mu \mathrm{g} / \mathrm{kg} / \mathrm{h}, \text { i.v) }\end{array}$ & $\begin{array}{c}0,2 \text { and } 4 \mathrm{~h} \text { after } \\
\text { ischemia } \\
\text { or } \\
\text { Immediately, } 5 \mathrm{~h} \text { after } \\
\text { occlusion and } \\
\text { continuing during } 4 \mathrm{~h}\end{array}$ & $\begin{array}{c}\downarrow \text { size and infarct } \\
\text { volume in the cerebral } \\
\text { cortex }\end{array}$ & $\begin{array}{c}\text { Mauler \& } \\
\text { Horváth, } 2005\end{array}$ \\
\hline MCAo/mice & $\begin{array}{l}\text { Cannabidiol } \\
\text { (1 and } 3 \\
\mathrm{mg} / \mathrm{kg} \text {, i.p. })\end{array}$ & $\begin{array}{l}\text { Immediately before } \\
\text { and } 3 \text { hours after } \\
\text { MCA occlusion }\end{array}$ & $\begin{array}{l}\downarrow \text { infarct volume in the } \\
\text { cerebral cortex } \\
\uparrow \text { cerebral blood flow } \\
{ }^{*} \text { Effects blocked by } \\
\text { WAY } 100635\end{array}$ & $\begin{array}{l}\text { Mishima et } \\
\text { al., } 2005\end{array}$ \\
\hline MCAo/rats & $\begin{array}{c}\text { Compound } 26 \\
(40 \mu \mathrm{g} / \mathrm{kg} / \mathrm{h} \\
\text { i.v. })\end{array}$ & $\begin{array}{c}\text { Infusion during } \\
4 \mathrm{~h} \text { immediately after } \\
\text { ischemia }\end{array}$ & $\begin{array}{c}\downarrow \text { size and infarct } \\
\text { volume in cerebral } \\
\text { cortex }\end{array}$ & $\begin{array}{l}\text { Marco et al., } \\
2011\end{array}$ \\
\hline MCAo/rats & $\begin{array}{c}\mathrm{S} 14671(0.06 \\
\mathrm{mg} / \mathrm{kg} / \mathrm{h}, i . v .) \\
\mathrm{S} 14671 \\
(0.75 \mathrm{mg} / \mathrm{kg} \\
\text { s.c). } \\
30 \text { min after } \\
\text { reperfusion }\end{array}$ & $\begin{array}{l}30 \text { min after } \\
\text { reperfusion and } \\
\text { continuing } 20 \mathrm{~h} \\
\\
30 \text { min after } \\
\text { reperfusion and } \\
\text { continuing } 3 \mathrm{~h}\end{array}$ & $\begin{array}{c}\downarrow \text { size and infarct } \\
\text { volume in the cerebral } \\
\text { cortex }\end{array}$ & $\begin{array}{l}\text { Johansen et } \\
\text { al., } 2014\end{array}$ \\
\hline
\end{tabular}




\begin{tabular}{|c|c|c|c|c|}
\hline & $\begin{array}{c}\text { Ipsapirone } \\
(0,25 \mathrm{mg} / \mathrm{kg} / \mathrm{h} \text {, } \\
\text { i.v. }) \\
\\
\\
\text { Ipsapirone } \\
(0.75 \mathrm{mg} / \mathrm{kg} \text {, } \\
\text { i.v) }\end{array}$ & $\begin{array}{l}30 \text { min after } \\
\text { reperfusion }\end{array}$ & & \\
\hline \multicolumn{5}{|c|}{$\mathrm{TGCl}$} \\
\hline $\begin{array}{c}\text { Animal } \\
\text { model/specie }\end{array}$ & Treatment & Administration & $\begin{array}{c}\text { Histopathology / } \\
\text { Functional } \\
\text { parameters } \\
\end{array}$ & Reference \\
\hline 2-Vo/rats & $\begin{array}{c}\text { CM } 57943(1, \\
5,10 \mathrm{mg} / \mathrm{kg}, \\
\text { i.p.) } \\
\text { CM } 57943(1, \\
\text { 5, } 10 \mathrm{mg} / \mathrm{kg}, \\
\text { i.p.) } \\
\text { Urapidil (80 } \\
\mathrm{mg} / \mathrm{kg}, \text { i.p.) }\end{array}$ & $\begin{array}{c}30 \text { min before } \\
\text { ischemia } \\
\text { Immediately and } 60 \\
\text { min after ischemia }\end{array}$ & $\begin{array}{l}\downarrow \text { neuronal loss in the } \\
\text { CA1 hippocampal } \\
\text { subarea (CM 57943) }\end{array}$ & $\begin{array}{l}\text { Prehn et al., } \\
1991\end{array}$ \\
\hline 2-Vo/rats & $\begin{array}{l}\text { Ipsapirone (10 } \\
\text { mg/kg, i.p.) } \\
\text { CM 57943 (10 } \\
\text { mg/kg, i.p.) } \\
\text { Urapidil (80 } \\
\text { mg/kg, i.p.) }\end{array}$ & $\begin{array}{l}30 \text { min before } \\
\text { ischemia }\end{array}$ & $\begin{array}{c}\downarrow \text { neuronal loss in the } \\
\text { CA1, CA2, CA3 } \\
\text { hippocampal subareas } \\
\text { and entorhinal cortex }\end{array}$ & $\begin{array}{l}\text { Prehn et al., } \\
1993\end{array}$ \\
\hline 2-VO/rats & $\begin{array}{l}\text { Repinotan (4 } \\
\mu \mathrm{g} / \mathrm{kg}, \text { i.v.) }\end{array}$ & $\begin{array}{l}\text { Infusion during } 4 \mathrm{~h} \\
\text { immediately after } \\
\text { ischemia }\end{array}$ & $\begin{array}{c}\downarrow \text { neuronal loss in the } \\
\text { CA1 hippocampal } \\
\text { subarea } \\
\downarrow \text { apoptosis (TUNEL) } \\
\text { *Effects abolished } \\
\text { by WAY100635 }\end{array}$ & $\begin{array}{l}\text { Schaper et } \\
\text { al., } 2000\end{array}$ \\
\hline 2-VO/rats & $\begin{array}{c}8-O H-D P A T \\
(125 \mu \mathrm{g} / \mathrm{kg} / \mathrm{h}, \\
\text { i.v. })\end{array}$ & $\begin{array}{l}\text { Infusion during } 7 \\
\text { days immediately } \\
\text { after ischemia }\end{array}$ & $\begin{array}{c}\downarrow \text { neuronal loss in the } \\
\text { CA1 hippocampal } \\
\text { subarea }\end{array}$ & $\begin{array}{l}\text { Torup et al., } \\
2000\end{array}$ \\
\hline & & & & \\
\hline
\end{tabular}




\begin{tabular}{|c|c|c|c|c|}
\hline $\begin{array}{l}\text { BCCAO/ } \\
\text { Mongolian } \\
\text { gerbil }\end{array}$ & $\begin{array}{l}\text { Ipsapirone (3 } \\
\text { mg/kg, i.p.) } \\
\text { Bay R 1531 (3 } \\
\text { mg/kg, i.p.) }\end{array}$ & $\begin{array}{c}15 \text { min before } \\
\text { followed by } 2 x / \text { day } \\
\text { during } 3 \text { days }\end{array}$ & $\begin{array}{c}\downarrow \text { neuronal loss in the } \\
\text { CA1 hippocampal } \\
\text { subarea }\end{array}$ & $\begin{array}{c}\text { Bode-Greuel } \\
\text { et al., } 1990\end{array}$ \\
\hline $\begin{array}{l}\text { BCCAO/ } \\
\text { Mongolian } \\
\text { gerbil }\end{array}$ & $\begin{array}{c}\text { 8-OH-DPAT } \\
\text { (1 and } 3 \\
\text { mg/kg, i.p.) } \\
\text { Buspirone (3 } \\
\text { and } 10 \mathrm{mg} / \mathrm{kg}, \\
\text { i.p.) } \\
\text { Flesinoxan (1 } \\
\text { and } 3 \mathrm{mg} / \mathrm{kg} \text {, } \\
\text { i.p.) }\end{array}$ & $\begin{array}{c}15 \text { min before } \\
\text { ischemia, followed by } \\
2 x / \text { day during } 3 \text { days }\end{array}$ & $\begin{array}{c}\downarrow \text { neuronal loss in the } \\
\text { CA1 hippocampal } \\
\text { subarea } \\
\text { (8-OH-DPAT) } \\
\downarrow \text { hyperlocomotion } \\
\text { induced by BCCAO }\end{array}$ & $\begin{array}{l}\text { Piera et al., } \\
\quad 1995\end{array}$ \\
\hline $\begin{array}{l}\text { BCCAO/ } \\
\text { Mongolian } \\
\text { gerbil }\end{array}$ & $\begin{array}{c}\text { 8-OH-DPAT } \\
(1 \mathrm{mg} / \mathrm{kg}, \text { s.c. })\end{array}$ & $\begin{array}{l}30 \text { min before } \\
\text { ischemia }\end{array}$ & $\begin{array}{c}\downarrow \text { neuronal loss in CA1 } \\
\text { hippocampal subarea } \\
\uparrow \text { BDNF levels in the } \\
\text { CA1 hippocampal } \\
\text { subregion } \\
\downarrow \text { NR1 receptor subunit } \\
\text { expression }\end{array}$ & $\begin{array}{l}\text { Salazar- } \\
\text { Colocho et al., } \\
\text { 2007; } 2008\end{array}$ \\
\hline $\begin{array}{l}\mathrm{BCCAO} / \\
\text { mice }\end{array}$ & $\begin{array}{c}\mathrm{NLX}-101(0.32 \\
\mathrm{mg} / \mathrm{kg} \text {, i.p. })\end{array}$ & $\begin{array}{c}\text { Once a day } 1 \text { week } \\
\text { before and during } 21 \\
\text { days after ischemia }\end{array}$ & $\begin{array}{c}\downarrow \text { memory deficits and } \downarrow \\
\text { despair-like behaviors } \\
\uparrow \text { BDNF in the } \\
\text { hippocampus and PFC } \\
\uparrow \text { PSD-95 and } \uparrow \\
\text { synaptophysin in the } \\
\text { hippocampus } \\
\text { (+) Dendritic remodeling } \\
\text { in the hippocampus and } \\
\text { PFC }\end{array}$ & $\begin{array}{c}\text { Aguiar et al., } \\
2019\end{array}$ \\
\hline
\end{tabular}

MCAo, middle cerebral artery occlusion; BCCAO, Bilateral common carotid arteries; 2-VO, Two vessels occlusion; BDNF, brain derived neurotrophic factor; PFC, prefrontal cortex; PTBBS, peripheral type benzodiazepine binding sites; PSD-95, postsynaptic density protein; $\uparrow$, increase; $\downarrow$, decrease; (+), positive effect.

\section{New perspectives for targeting 5-HT $1 \mathrm{~A}$ receptors: 'biased' receptor agonists}

\section{differentiating between receptor subpopulations}


The studies described above and listed in Table 2 provide a clear demonstration that parameters associated with cerebral ischemia, can be reduced via activation of 5 $H \mathrm{~T}_{1 \mathrm{~A}}$ receptors. Overall, $5-\mathrm{HT}_{1 \mathrm{~A}}$ receptor agonists reduced the size and infarct volume in the cerebral cortex of rodents subjected to MCAo and prevented hippocampal neuronal loss in the hippocampus of rodents with global cerebral ischemia. Such studies buttress the rationale for pursuing investigation of this class of compounds and suggest that they could lead to promising pharmacotherapeutics. Nevertheless, the clinical benefits for ischemia patients are currently far from impressive. The only commercialized drug in Table 2 is buspirone, which is commonly used as an anxiolytic though it has attracted little (if any) attention as a clinical anti-ischemia treatment. Interestingly it has been used as an anti-shivering treatment during the intervention by cooling body temperature because if left uncontrolled, shivering can defeat the cooling process and eliminate the potential benefits of therapeutic intervention in brain ischemia, see EuroHYP-1 and ICTuS2/3 trials on clinicaltrials.gov. Some of the other compounds, including ipsapirone and gepirone, are close clinical analogs of buspirone and possess similar pharmacological profiles, i.e., partial agonist properties at $5-\mathrm{HT}_{1 \mathrm{~A}}$ receptors and some limited selectivity over multiple other cross-reacting sites, including dopaminergic and adrenergic receptors. Similar limitations also apply to urapidil and piclozotan although not to repinotan, which is potent and selective for $5-\mathrm{HT}_{1 \mathrm{~A}}$ receptors. As surmised by Piera et al. (1995), the limited neuroprotective effects of at least some of the tested compounds may also be actually due to their insufficient agonist efficacy at $5-\mathrm{HT}_{1 \mathrm{~A}}$ receptors. Thus, modest-efficacy partial receptor agonism may be insufficient to elicit an optimal therapeutic benefit. 
Another important point to consider is that the tested compounds interact broadly with $5-\mathrm{HT}_{1 \mathrm{~A}}$ receptor subpopulations throughout the brain, irrespective of neuronal or regional localization. This lack in receptor discrimination may be a limiting factor in the anti-ischemic efficacy of the agonists because $5-\mathrm{HT}_{1 \mathrm{~A}}$ receptors in different brain regions can mediate diverging or even contradictory responses. For example, activation of $5-\mathrm{HT}_{1 \mathrm{~A}}$ autoreceptors in the raphe inhibits serotonergic tone and dampens 5-HT release throughout terminal regions, thus indirectly opposing activation of postsynaptic $5-\mathrm{HT}_{1 \mathrm{~A}}$ receptors (Figure 2). Moreover, as described above, the preferential targeting by biased agonist of raphe-located 5- $\mathrm{HT}_{1 \mathrm{~A}}$ autoreceptors or postsynaptic heteroreceptors is not due to differences in the receptor protein itself or binding affinity per se. The distinct responses to the biased $5-\mathrm{HT}_{1 \mathrm{~A}}$ agonists have been attributable to regional coupling differences of 5- $\mathrm{HT}_{1 \mathrm{~A}}$ receptor to certain G-protein subtypes, regulators of G-protein signaling, or transcriptional regulation (Newman-Tancredi, 2011). There are distinct regional intracellular signaling responses to postsynaptic $5-\mathrm{HT}_{1 \mathrm{~A}}$ receptor activation: ERK1/2 signaling, which is important for neuroprotective activity, varies in different brain regions (vide supra) and is known to be stimulated by $5-\mathrm{HT}_{1 \mathrm{~A}}$ receptors in the cortex and hippocampus.

Taken together, these considerations suggest that improved treatment of ischemia may require $5-\mathrm{HT}_{1 \mathrm{~A}}$ receptor agonists that fulfill 3 conditions: (i) high receptor selectivity, (ii) efficacious receptor activation (full agonism), and (iii) functional selectivity for ERK1/2 activation in vulnerable brain regions expressing postsynaptic $5-\mathrm{HT}_{1 \mathrm{~A}}$ heteroreceptors. These criteria have not previously been met by classical $5-\mathrm{HT}_{1 \mathrm{~A}}$ receptor agonists but a new generation of compounds has become available that discriminate between receptor 
subpopulations in specific brain regions (Sniecikowska et al., 2019). An extensive series of in vitro, ex vivo, electrophysiological, neurochemical, behavioral, and brain imaging studies have shown that these 'biased agonists' differentially target $5-\mathrm{HT}_{1 \mathrm{~A}}$ autoreceptors or postsynaptic 5- $\mathrm{HT}_{1 \mathrm{~A}}$ heteroreceptors in different brain regions (Newman-Tancredi, 2011). The prototypical postsynaptic $5-\mathrm{HT}_{1 \mathrm{~A}}$ receptor biased agonist is $\mathrm{NLX}-101$ (also known as F15599), a compound that preferentially and potently activates ERK1/2 phosphorylation and elicits cortical pyramidal neuron electrical activity without inhibiting serotonin neuron firing (Newman-Tancredi et al., 2009; Llado-Pelfort et al., 2010). NLX101 is undergoing early clinical development for breathing difficulties in Rett's syndrome and as a potential rapid-acting antidepressant. Indeed, NLX-101 exhibits procognitive and antidepressant activity in a variety of animal models (Depoortère et al., 2010; van Goethem et al., 2015; Depoortère et al., 2019). Notably, a recent study by Aguiar et al. (2020) showed that chronic treatment with NLX-101 attenuated cognitive impairments and despair-like behaviors induced by BCCAO in mice. Also, NLX-101 blocked the increase in plasma corticosterone levels and restored BDNF, synaptophysin, and PSD-95 protein levels in the hippocampus of mice subjected to BCCAO. These findings are significant because they suggest that preferential targeting of postsynaptic $5-\mathrm{HT}_{1 \mathrm{~A}}$ receptors may be able to rescue the neurostructural damage induced by BCCAO as well as its functional deficits on mood and cognitive function. If these findings can be translated into a clinical setting, they could provide a novel basis for the development of 'biased' $5-\mathrm{HT}_{1 \mathrm{~A}}$ heteroreceptor agonists in the treatment of ischemia.

\section{General considerations and conclusions}


The primary purpose of neuroprotective pharmacotherapy is to reduce the severity of initial damage and improve functional outcomes in the weeks and months after a cerebral ischemic event. In this review, we presented experimental evidence that $5-\mathrm{HT}_{1 \mathrm{~A}}$ receptor agonists were able to prevent the neuronal damage induced by transient focal or global cerebral ischemia. Indeed, over several decades abundant evidence has been provided that $5-\mathrm{HT}_{1 \mathrm{~A}}$ receptors are involved in several processes that may attenuate cerebral ischemic injury at varying time points. Agonist activation of $5-\mathrm{HT}_{1 \mathrm{~A}}$ receptors can promote hyperpolarization due to an increase in the inwardly rectifying potassium current and inhibit ischemia-induced excessive damage due to glutamate release. Besides, 5$\mathrm{HT}_{1 \mathrm{~A}}$ receptor agonists have been reported to exert neuroprotective effects by promoting hypothermia. Finally, $5-\mathrm{HT}_{1 \mathrm{~A}}$ receptor agonists have been involved in the neuroplastic changes in the hippocampus, including an increase in BDNF and neurogenesis which are reduced after a cerebral ischemic event.

Nevertheless, despite these compelling findings, little progress has been made in translating them into a clinical application. Most of the preclinical studies have focused on acute or short-term treatments, i.e., before, immediately after, or during 3 to 7 days after cerebral ischemia (Table 2), to promote neuronal survival. The main measurement (outcome) was the histological damage in vulnerable areas (cortical infarct size for MCAo and hippocampal cell loss for TGCI). However, the promotion of neuronal survival is of little therapeutic utility unless followed by successful brain remodeling and plasticity which is which $5-\mathrm{HT}_{1 \mathrm{~A}}$ receptor agonists produce neuroprotection need more clarification and systematic studies. Only two studies confirmed direct $5-\mathrm{HT}_{1 \mathrm{~A}}$ receptor involvement by showing that the neuroprotective effect of $5-\mathrm{HT}_{1 \mathrm{~A}}$ receptor agonists was blocked by a 
5-HT 1 A receptor antagonist, WAY100635 (Schaper et al., 2000; Mishima et al., 2005). Restoring functional deficits in ischemic patients is critical for improvements in the patient's quality of life and is, therefore, an important measure of a treatment's therapeutic potential in animal models (Liao et al., 2008; Veerbeek et al., 2011). To our knowledge, only two studies measured functional recovery with a $5-\mathrm{HT}_{1 \mathrm{~A}}$ receptor agonist after cerebral ischemia (Piera et al., 1995; Aguiar et al., 2020). Interestingly, one of those studies indicates that the postsynaptic $5-\mathrm{HT}_{1 \mathrm{~A}}$ heteroreceptor is involved in both neuroprotection and functional recovery, drawing attention to a possible novel and promising strategy for improved therapeutic intervention. A bias for postsynaptic receptors is important as excessive and indistinct activation of both pre- and postsynaptic $5-\mathrm{HT}_{1 \mathrm{~A}}$ receptors may induce a broad range of physiological effects related to the expression of these receptors in different brain regions. Hence, as well as the desired neuroprotective properties, 5- $\mathrm{HT}_{1 \mathrm{~A}}$ receptor activation can elicit autonomic, neuroendocrine, neuropsychiatric, and hypothermic effects, depending on the brain regions involved. In this context, it is important to note that the classical $5-\mathrm{HT}_{1 \mathrm{~A}}$ receptor agonists activate indiscriminately both $5-\mathrm{HT}_{1 \mathrm{~A}}$ autoreceptors, which induce an inhibitory effect on serotonergic tone, and postsynaptic heteroreceptors, which are associated with inducing a positive effect on neuroprotective mechanisms. Such lack of functional selectivity may result in a limited net beneficial effect of such agonists, possibly dampening therapeutic efficacy and thus reducing their clinical applications. The development of a biased $5-\mathrm{HT}_{1 \mathrm{~A}}$ receptor agonist targeting postsynaptic heteroreceptors might overcome such limitations and represent an attractive therapeutic strategy to provide neuroprotection in ischemic cerebral conditions. 


\section{References}

Adayev T, El-Sherif Y, Barua M, Penington NJ, Banerjee P. 1999. Agonist stimulation of the serotonin $1 \mathrm{~A}$ receptor causes suppression of anoxia-induced apoptosis via mitogen-activated protein kinase in neuronal HN2-5 cells. J Neurochem. 72(4):1489-96. https://doi.org/10.1046/j.1471-4159.1999.721489.x

Adayev T, Ray I, Sondhi R, Sobocki T, Banerjee P. 2003. The G protein-coupled 5-HT1A receptor causes suppression of caspase-3 through MAPK and protein kinase Calpha. Biochim Biophys Acta. 1640(1):85-96. https://doi.org/:10.1016/s01674889(03)00023-5

Aguiar RP, Soares LM, Meyer E, et al. 2020. Activation of 5-HT ${ }_{1 A}$ postsynaptic receptors by NLX-101 results in functional recovery and an increase in neuroplasticity in mice with brain ischemia. Prog Neuropsychopharmacol Biol Psychiatry. 99:109832. https://doi.org/10.1016/j.pnpbp.2019.109832

Albert PR, Vahid-Ansari F. 2019. The 5-HT1A receptor: Signaling to behavior. Biochimie. 161:34-45. https://doi.org/10.1016/j.biochi.2018.10.015

Albert PR, Zhou QY, Van Tol HH, Bunzow JR, Civelli O. 1990. Cloning, functional expression, and mRNA tissue distribution of the rat 5-hydroxytryptamine1A receptor gene. J Biol Chem. 265(10):5825-32

Alexander LD, Black SE, Gao F, Szilagyi G, Danells CJ, Mcllroy WE. 2010. Correlating lesion size and location to deficits after ischemic stroke: the influence of accounting for altered peri-necrotic tissue and incidental silent infarcts. Behav Brain Funct. 6:6. https://doi.org/10.1186/1744-9081-6-6

Anderson CA, Arciniegas DB. 2010. Cognitive sequelae of hypoxic-ischemic brain injury: a review. NeuroRehabilitation. 26(1):47-63. https://doi.org/10.3233/NRE-20100535

Anrather J, Iadecola C. 2016. Inflammation and Stroke: An Overview. Neurotherapeutics. 13(4):661-670. https://doi.org/10.1007/s13311-016-0483-x

Ayerbe L, Ayis S, Wolfe CD, Rudd AG. 2013. Natural history, predictors and outcomes of depression after stroke: systematic review and meta-analysis. $\mathrm{Br} J$ Psychiatry. 202(1):14-21. https://doi.org/10.1192/bjp.bp.111.107664.

Bang SJ, Jensen P, Dymecki SM, Commons KG. 2012. Projections and interconnections of genetically defined serotonin neurons in mice. Eur $J$ Neurosci. 35(1):85-96. https://doi.org/10.1111/j.1460-9568.2011.07936.x

Bardutzky J, Shen Q, Henninger N, Bouley J, Duong TQ, Fisher M. 2005. Differences in ischemic lesion evolution in different rat strains using diffusion and perfusion imaging.

Stroke. https://doi.org/10.1161/01.STR.0000177486.85508.4d

Benjamin EJ, Virani SS, Callaway CW, et al. 2018. American Heart Association Council on Epidemiology and Prevention Statistics Committee and Stroke Statistics Subcommittee. Heart Disease and Stroke Statistics-2018 Update: A Report From the American Heart Association. Circulation. 137(12):e67-e492. https://doi.org/10.1161/CIR.0000000000000558

Beck T, Lindholm D, Castrén E, Wree A. 1994. Brain-derived neurotrophic factor protects against ischemic cell damage in rat hippocampus. J Cereb Blood Flow Metab. 14(4):689-92. https://doi.org/10.1038/jcbfm.1994.86 
Berends AC, Luiten PG, Nyakas C. 2005. A review of the neuroprotective properties of the 5-HT1A receptor agonist repinotan $\mathrm{HCl}$ (BAYx3702) in ischemic stroke. CNS Drug Rev.11(4):379-402. https://doi.org/10.1111/j.1527-3458.2005.tb00055.x

Bielenberg GW, Burkhardt M. 1990. 5-hydroxytryptamine1A agonists. A new therapeutic principle for stroke treatment. Stroke. 21(12 Suppl):IV161-IV163.

Bode-Greuel KM, Klisch J, Horváth E, Glaser T, Traber J. 1990. Effects of 5hydroxytryptamine1A-receptor agonists on hippocampal damage after transient forebrain ischemia in the Mongolian gerbil. Stroke. 21(12 Suppl):IV164-IV166.

Bockaert J, Claeysen S, Dumuis A, Marin P. 2010. Classification and Signaling Characteristics of 5-HT Receptors. Christian P. Müller; Barry L. Jacobs. Handbook of the Behavioral Neurobiology of Serotonin, 21, Elsevier, pp.103-121, Handbook of Behavioral Neuroscience, 978-0-12-374634-4.

Bockaert J, Claeysen S, Compan V, Dumuis A. 2004. 5-HT4 receptors. Curr Drug Targets CNS Neurol Disord. 3(1):39-51. https://doi.org/10.2174/1568007043482615

Blendy JA. 2006. The role of CREB in depression and antidepressant treatment. Biol Psychiatry. 59(12):1144-1150. https://doi.org/10.1016/j.biopsych.2005.11.003

Bruns D, Riedel D, Klingauf J, Jahn R. 2000. Quantal release of serotonin. Neuron. 28(1):205-220. https://doi.org/s0896-6273(00)00097-0

Bunin MA, Wightman RM. 1999. Paracrine neurotransmission in the CNS: involvement of 5-HT. Trends Neurosci. 22(9):377-382. https://doi.org/10.1016/s01662236(99)01410-1

Cassel JC, Jeltsch H. 1995. Serotoninergic modulation of cholinergic func-tion in the central nervous system: cognitive implications. Neuroscience. 69(1):1-41.

Carlezon WA Jr, Duman RS, Nestler EJ. 2005. The many faces of CREB. Trends Neurosci. 28(8):436-445. https://doi.org/10.1016/j.tins.2005.06.005

Carloni S, Girelli S, Scopa C, Buonocore G, Longini M, Balduini W. 2010. Activation of autophagy and Akt/CREB signaling play an equivalent role in the neuroprotective effect of rapamycin in neonatal hypoxia-ischemia. Autophagy. 6(3):366-77. https://doi.org/10.4161/auto.6.3.11261

Clarkson AN, Parker K, Nilsson M, Walker FR, Gowing EK. 2015. Combined ampakine and BDNF treatments enhance poststroke functional recovery in aged mice via AKT-CREB signaling. J Cereb Blood Flow Metab. 35(8):1272-1279. https://doi.org/10.1038/jcbfm.2015.33

Cowen DS, Johnson-Farley NN, Travkina T. 2005. 5-HT receptors couple to activation of Akt, but not extracellular-regulated kinase (ERK), in cultured hippocampal neurons. $J$ Neurochem. 93(4):910-917. https://doi.org/10.1111/j.14714159.2005.03107.x

Celada P, Puig MV, Artigas F. 2013. Serotonin modulation of cortical neurons and networks. Front Integr Neurosci. 7:25. https://doi.org/10.3389/fnint.2013.00025

Colgan LA, Putzier I, Levitan ES. 2009. Activity-dependent vesicular monoamine transporter-mediated depletion of the nucleus supports somatic release by $\begin{array}{llll}\text { serotonin neurons. } J & \text { Neurosci. } & \text { 29(50):15878-15887. }\end{array}$ https://doi.org/10.1523/JNEUROSCI.4210-09.2009

Colgan LA, Cavolo SL, Commons KG, Levitan ES. 2012. Action potential-independent and pharmacologically unique vesicular serotonin release from dendrites. $J$ 
Neurosci. 32(45):15737-15746. https://doi.org/10.1523/JNEUROSCI.002012.2012

Codony X, Burgueño J, Ramírez MJ, Vela JM. 2010. 5-HT6 receptor signal transduction second messenger systems. Int Rev Neurobiol. 94:89-110. https://doi.org/10.1016/B978-0-12-384976-2.00004-6

Courtney NA, Ford CP. 2016. Mechanisms of 5-HT1A receptor-mediated transmission in dorsal raphe serotonin neurons. J Physiol. 594(4):953-965. https://doi.org/10.1113/JP271716

Chamorro Á, Dirnagl U, Urra X, Planas AM. 2016. Neuroprotection in acute stroke: targeting excitotoxicity, oxidative and nitrosative stress, and inflammation. Lancet Neurol. 15(8):869-881. https://doi.org/10.1016/S1474-4422(16)00114-9

Chan PH. 2001. Reactive oxygen radicals in signaling and damage in the ischemic brain. $J$ Cereb Blood Flow Metab. 21(1):2-14. https://doi.org/10.1097/00004647200101000-00002

Chameau P, van Hooft JA. 2006. Serotonin 5-HT(3) receptors in the central nervous system. Cell Tissue Res. 326(2):573-81. https://doi.org/10.1007/s00441-0060255-8

Chen J, Shen C, Meller E. 2002. 5-HT1A receptor-mediated regulation of mitogenactivated protein kinase phosphorylation in rat brain. Eur J Pharmacol. 452(2):155162. https://doi.org/10.1016/s0014-2999(02)02297-5

Chen GY, Nuñez G. 2010. Sterile inflammation: sensing and reacting to damage. Nat Rev Immunol. 10(12):826-37. https://doi.org/10.1038/nri2873

Chilmonczyk Z, Bojarski AJ, Pilc A, Sylte I. 2015. Functional Selectivity and Antidepressant Activity of Serotonin 1A Receptor Ligands. Int $\mathrm{J}$ Mol Sci. 16(8):18474-18506. https://doi.org/10.3390/ijms160818474

David DJ, Gardier AM. 2016. The pharmacological basis of the serotonin system: Application to antidepressant response. Encephale. 42(3):255-263. https://doi.org/10.1016/j.encep.2016.03.012

de Kock CP, Cornelisse LN, Burnashev N, et al. 2006. NMDA receptors trigger neurosecretion of $5-\mathrm{HT}$ within dorsal raphe nucleus of the rat in the absence of action potential firing. J Physiol. 577(Pt 3):891-905 https://doi.org/10.1113/jphysiol.2006.115311

De Vivo M, Maayani S. 1986. Characterization of the 5-hydroxytryptamine1a receptormediated inhibition of forskolin-stimulated adenylate cyclase activity in guinea pig and rat hippocampal membranes. J Pharmacol Exp Ther. 238(1):248-53.

Dirnagl U, ladecola C, Moskowitz MA. 1999. Pathobiology of ischaemic stroke: an integrated view. Trends Neurosci. 22(9):391-397. https://doi.org/10.1016/s01662236(99)01401-0

Dirnagl U. 2012. Pathobiology of injury after stroke: the neurovascular unit and beyond. Ann N Y Acad Sci. 1268:21-25. https://doi.org/10.1111/j.17496632.2012.06691.x

Dirnagl U, Endres M. 2014. Found in translation: preclinical stroke research predicts human pathophysiology, clinical phenotypes, and therapeutic outcomes. Stroke. 45(5):1510-1518. https://doi.org/10.1161/STROKEAHA.113.004075 
Ding G, Jiang Q, Li L, et al. 2008. Angiogenesis detected after embolic stroke in rat brain using magnetic resonance T2*Wl. Stroke. 39(5):1563-1568. https://doi.org/10.1161/STROKEAHA.107.502146

Della Rocca GJ, Mukhin YV, Garnovskaya MN, et al. 1999. Serotonin 5-HT1A receptormediated Erk activation requires calcium/calmodulin-dependent receptor endocytosis. J Biol Chem. 274(8):4749-4753. https://doi.org/10.1074/jbc.274.8.4749

Depoortère R, Auclair AL, Bardin L, Colpaert FC, Vacher B, Newman-Tancredi A. 2010. F15599, a preferential post-synaptic $5-\mathrm{HT} 1 \mathrm{~A}$ receptor agonist: activity in models of cognition in comparison with reference 5-HT1A receptor agonists. Eur Neuropsychopharmacol. https://doi.org/10.1016/j.euroneuro.2010.04.005

20(9):641-654.

Depoortère R, Papp M, Gruca P, et al. 2019. Cortical 5-hydroxytryptamine 1A receptor biased agonist, NLX-101, displays rapid-acting antidepressant-like properties in the rat chronic mild stress model. J Psychopharmacol. 33(11):1456-1466. https://doi.org/10.1177/0269881119860666

Debata PR, Ranasinghe B, Berliner A, Curcio GM, Tantry SJ, Ponimaskin E, Banerjee P. 2010. Erk1/2-dependent phosphorylation of PKCalpha at threonine 638 in hippocampal 5-HT(1A) receptor-mediated signaling. Biochem Biophys Res Commun. 397(3):401-6. https://doi.org/10.1016/j.bbrc.2010.05.096

Delavaran H, Jönsson AC, Lövkvist H, Iwarsson S, Elmståhl S, Norrving B, Lindgren A. 2017. Cognitive function in stroke survivors: A 10-year follow-up study. Acta Neurol Scand. 136(3):187-194. https://doi.org/10.1111/ane.12709

Eglen RM, Wong EH, Dumuis A, Bockaert J. 1995. Central 5-HT4 receptors. Trends Pharmacol Sci. 16(11):391-8. https://doi.org/10.1016/s0165-6147(00)89081-1

Ferguson SS, Zhang J, Barak LS, Caron MG. 1996. G-protein-coupled receptor kinases and arrestins: regulators of G-protein-coupled receptor sequestration. Biochem Soc Trans. 24(4):953-959. https://doi.org/10.1042/bst0240953

Feijó Fde M, Bertoluci MC, Reis C. 2010. Serotonin and hypothalamic control of hunger: a review. Rev Assoc Med Bras. 57(1):74-77. https://doi.org/10.1016/S22554823(11)70020-0

Flynn RW, MacWalter RS, Doney AS. 2008. The cost of cerebral ischemia. Neuropharmacology. https://doi.org/10.1016/j.neuropharm.2008.05.031

Freedman NJ, Lefkowitz RJ. 1996. Desensitization of $G$ protein-coupled receptors. Recent Prog Horm Res. 51:319-353.

Freund TF, Gulyas Al, Acsady L, Gorcs T, Toth K. 1990. Serotonergic control of the hippocampus via local inhibitory interneurons. Proc Natl Acad Sci USA. 87:85018505. https://doi.org/10.1073/pnas.87.21.8501

Fitzpatrick PF. 1999. Tetrahydropterin-dependent amino acid hydroxylases. Annu Rev Biochem. 68:355-81. https://doi.org/10.1146/annurev.biochem.68.1.355

Fukuyama N, Takizawa S, Ishida H, Hoshiai K, Shinohara Y, Nakazawa H. 1998. Peroxynitrite formation in focal cerebral ischemia-reperfusion in rats occurs predominantly in the peri-infarct region. J Cereb Blood Flow Metab. 18(2):123-9. https://doi.org/10.1097/00004647-199802000-00001 
Gaspar P, Lillesaar C. 2012. Probing the diversity of serotonin neurons. Philos Trans $R$ Soc Lond B Biol Sci. 367(1601):2382-2394. https://doi.org/10.1098/rstb.2011.0378

Gelderblom M, Leypoldt F, Steinbach K, Behrens D, Choe CU, Siler DA, Arumugam TV, Orthey E, Gerloff C, Tolosa E, Magnus T. 2009. Temporal and spatial dynamics of cerebral immune cell accumulation in stroke. Stroke. 40(5):1849-57. https://doi.org/10.1161/STROKEAHA.108.534503

Gellynck E, Heyninck K, Andressen KW, Haegeman G, Levy FO, Vanhoenacker P, Van Craenenbroeck K. 2013. The serotonin 5-HT7 receptors: two decades of research. Exp Brain Res. 230(4):555-68. https://doi.org/10.1007/s00221-013-3694-y

Gennaro M, Mattiello A, Pizzorusso T. 2019. Rodent Models of Developmental Ischemic Stroke for Translational Research: Strengths and Weaknesses. Neural Plast. 2019:5089321. https://doi.org/10.1155/2019/5089321

Ginsberg MD. 2008. Neuroprotection for ischemic stroke: past, present and future. Neuropharmacology.55(3):363-389.

https://doi.org/10.1016/j.neuropharm.2007.12.007

Geri G, Mongardon N, Daviaud F, Empana JP, Dumas F, Cariou A. 2014. Neurological consequences of cardiac arrest: where do we stand?. Ann Fr Anesth Reanim. 33(2):98-101. https://doi.org/10.1016/j.annfar.2013.11.003

Garcia-Garcia AL, Newman-Tancredi A, Leonardo ED. 2014. 5-HT(1A) receptors in mood and anxiety: recent insights into autoreceptor versus heteroreceptor function. Psychopharmacology $\quad$ (Berl). 231(4):623-636. https://doi.org/10.1007/s00213-013-3389-x

Hannon J, Hoyer D. 2008 Molecular biology of 5-HT receptors. Behav Brain Res. 195(1):198-213. https://doi.org/10.1016/j.bbr.2008.03.020.

Halasy K, Miettinen R, Szabat E, Freund TF. 1992. GABAergic interneurons are the major postsynaptic targets of median raphe afferents in the rat dentate gyrus. Eur $J$ Neurosci. 4: 144-153. https://doi.org/10.1111/j.1460-9568.1992.tb00861.x

Hackett ML, Pickles K. 2014. Part I: frequency of depression after stroke: an updated systematic review and meta-analysis of observational studies. Int J Stroke. 9(8):1017-25. https://doi.org/10.1111/ijs.12357

Haleem DJ. 2019. Targeting Serotonin1A Receptors for Treating Chronic Pain and Depression. Curr Neuropharmacol. https://doi.org/10.2174/1570159X17666190811161807

Hermann DM, Doeppner TR, Popa-Wagner A. 2019. Opportunities and Limitations of Vascular Risk Factor Models in Studying Plasticity-Promoting and Restorative Ischemic Stroke Therapies. Neural Plast. 2019:9785476. https://doi.org/10.1155/2019/9785476

Hsiung SC, Tamir H, Franke TF, Liu KP. 2005. Roles of extracellular signal-regulated kinase and Akt signaling in coordinating nuclear transcription factor-kappaBdependent cell survival after serotonin $1 \mathrm{~A}$ receptor activation. $J$ Neurochem. 95(6):1653-1666. https://doi.org/10.1111/j.1471-4159.2005.03496.x

Hoyer D, Clarke DE, Fozard JR, et al. 1994. International Union of Pharmacology classification of receptors for 5-hydroxytryptamine (Serotonin). Pharmacol Rev. 46(2):157-203.

Hoffmann T, Bennett S, Koh CL, McKenna K. 2010. A systematic review of cognitive interventions to improve functional ability in people who have cognitive impairment 
following stroke. Top Stroke Rehabil. 17(2):99-107. https://doi.org/10.1310/tsr1702-99

Hjorth S, Sharp T. 1991. Effect of the 5-HT1A receptor agonist 8-OH-DPAT on the release of $5-\mathrm{HT}$ in dorsal and median raphe-innervated rat brain regions as measured by in vivo microdialysis. Life Sci. 48(18):1779-1786. https://doi.org/10.1016/00243205(91)90216-x

Jacobs BL, Azmitia EC. 1992. Structure and function of the brain serotonin system. Physiol Rev. 72(1):165-229.

https://doi.org/10.1152/physrev.1992.72.1.165

Johansen FF, Hasseldam H, Nybro Smith M, Rasmussen RS. 2014. Drug-induced hypothermia by $5 \mathrm{HT} 1 \mathrm{~A}$ agonists provide neuroprotection in experimental stroke: new perspectives for acute patient treatment. J Stroke Cerebrovasc Dis. 23(10):2879-2887. https://doi.org/10.1016/j.jstrokecerebrovasdis.2014.07.019

Johnson CO, Nguyen M, Roth GA, et al., 2019. Global, regional, and national burden of stroke, 1990-2016: a systematic analysis for the Global Burden of Disease Study 2016. Lancet Neurol. 18(5):439-458. https://doi.org/10.1016/S14744422(19)30034-1

Justicia C, Panés J, Solé S, Cervera A, Deulofeu R, Chamorro A, Planas AM. 2003. Neutrophil infiltration increases matrix metalloproteinase-9 in the ischemic brain after occlusion/reperfusion of the middle cerebral artery in rats. J Cereb Blood Flow Metab. 23(12):1430-40. https://doi.org/10.1097/01.WCB.0000090680.07515.C8

Kamei K, Maeda N, Ogino R, et al. 2001. New 5-HT1A receptor agonists possessing 1,4benzoxazepine scaffold exhibit highly potent anti-ischemic effects. Bioorg Med Chem Lett. 11(4):595-598. https://doi.org/10.1016/s0960-894x(01)00008-7

Knapp P, Dunn-Roberts A, Sahib N, Cook L, Astin F, Kontou E, Thomas SA. 2020. Frequency of anxiety after stroke: An updated systematic review and metaanalysis of observational studies. Int $J$ Stroke. 15(3):244-255. https://doi.org/10.1177/1747493019896958

Kushwaha N, Albert PR. 2005. Coupling of 5-HT1A autoreceptors to inhibition of mitogenactivated protein kinase activation via $\mathrm{G}$ beta gamma subunit signaling. Eur $\mathrm{J}$ Neurosci. 21(3):721-732. https://doi.org/10.1111/j.1460-9568.2005.03904.x

Kukley M, Schaper C, Becker A, Rose K, Krieglstein J. 2001. Effect of 5hydroxytryptamine $1 \mathrm{~A}$ receptor agonist $\mathrm{BAY} X 3702$ on $\mathrm{BCL}-2$ and $\mathrm{BAX}$ proteins level in the ipsilateral cerebral cortex of rats after transient focal ischaemia. Neuroscience. 107(3):405-413. https://doi.org/10.1016/s03064522(01)00369-4

Khodanovich M, Kisel A. 2015. Animal models of cerebral ischemia. AIP Conference Proceedings, 1688:030037. https://doi.org/10.1063/1.4936032

Kim IJ, Drahushuk KM, Kim WY, et al. 2004. Extracellular signal-regulated kinases regulate dendritic growth in rat sympathetic neurons. J Neurosci. 24(13):33043312. https://doi.org/10.1523/JNEUROSCI.3286-03.2004

Kim DH, Li H, Yoo KY, Lee BH, Hwang IK, Won MH. 2007. Effects of fluoxetine on ischemic cells and expressions in BDNF and some antioxidants in the gerbil hippocampal CA1 region induced by transient ischemia. Exp Neurol. 204(2):74858. https://doi.org/10.1016/j.expneurol.2007.01.008 
Kim YR, Kim HN, Hong KW, Shin HK, Choi BT. 2016. Anti-depressant effects of phosphodiesterase 3 inhibitor cilostazol in chronic mild stress-treated mice after ischemic stroke. Psychopharmacology (Berl). 233(6):1055-66. https://doi.org/10.1007/s00213-015-4185-6

Kitagawa K. 2007. CREB and CAMP response element-mediated gene expression in the ischemic brain. FEBS J. 274(13):3210-7. https://doi.org/10.1111/j.17424658.2007.05890.x

Kleinig TJ, Vink R. 2009. Suppression of inflammation in ischemic and hemorrhagic stroke: therapeutic options. Curr Opin Neurol. 22(3):294-301. https://doi.org/10.1097/wco.0b013e32832b4db3.

Lawrence ES, Coshall C, Dundas R, Stewart J, Rudd AG, Howard R, Wolfe CD. 2001. Estimates of the prevalence of acute stroke impairments and disability in a multiethnic population. Stroke. 32(6):1279-84. https://doi.org/10.1161/01.str.32.6.1279

Leker RR, Shohami E. 2002. Cerebral ischemia and trauma-different etiologies yet similar mechanisms: neuroprotective opportunities. Brain Res Brain Res Rev. 39(1):5573. https://doi.org/10.1016/s0165-0173(02)00157-1

León-Moreno LC, Castañeda-Arellano R, Rivas-Carrillo JD, Dueñas-Jiménez SH. 2020. Challenges and Improvements of Developing an Ischemia Mouse Model Through Bilateral Common Carotid Artery Occlusion. J Stroke Cerebrovasc Dis. 29(5):104773. https://doi.org/10.1016/j.jstrokecerebrovasdis.2020.104773

Lee $\mathrm{CH}$, Park JH, Yoo KY, Choi JH, Hwang IK, Ryu PD, Kim DH, Kwon YG, Kim YM, Won $\mathrm{MH}$. 2011. Pre- and post-treatments with escitalopram protect against experimental ischemic neuronal damage via regulation of BDNF expression and $\begin{array}{llll}\text { oxidative stress. } & \text { Exp } & \text { 229(2):450-9. }\end{array}$ https://doi.org/10.1016/j.expneurol.2011.03.015

Lee $\mathrm{CH}$, Ahn JH, Won MH. 2015. New expression of 5-HT1A receptor in astrocytes in the gerbil hippocampal CA1 region following transient global cerebral ischemia. Neurol Sci. 36(3):383-389. https://doi.org/10.1007/s10072-014-1958-3

Li LX, Cheng YF, Lin HB, Wang C, Xu JP, Zhang HT. 2011. Prevention of cerebral ischemia-induced memory deficits by inhibition of phosphodiesterase-4 in rats. Metab Brain Dis. 26(1):37-47. https://doi.org/10.1007/s11011-011-9235-0

Liu YF, Albert PR. 1991. Cell-specific signaling of the 5-HT1A receptor. Modulation by protein kinases C and A. J Biol Chem. 266(35):23689-97.

Liesz A, Kleinschnitz C. 2015. Editorial: Mechanisms of neuroinflammation and inflammatory neurodegeneration in acute brain injury. Front Cell Neurosci. 9:300. https://doi.org/10.3389/fncel.2015.00300

Liao F, Wang J, He P. 2008. Multi-resolution entropy analysis of gait symmetry in neurological degenerative diseases and amyotrophic lateral sclerosis. Med Eng Phys. 30(3):299-310. https://doi.org/10.1016/j.medengphy.2007.04.014

Lin SL, Setya S, Johnson-Farley NN, Cowen DS. 2002. Differential coupling of 5-HT(1) receptors to $\mathrm{G}$ proteins of the $\mathrm{G}(\mathrm{i})$ family. $\mathrm{Br} J$ Pharmacol. 136(7):1072-1078. https://doi.org/10.1038/sj.bjp.0704809

Mannoury la Cour C, El Mestikawy S, Hanoun N, Hamon M, Lanfumey L. 2006. Regional differences in the coupling of 5-hydroxytryptamine-1A receptors to $G$ proteins in 
the rat brain. Mol Pharmacol. 70(3):1013-21. https://doi.org/10.1124/mol.106.022756.

Maddaloni G, Bertero A, Pratelli M, et al. 2017. Development of Serotonergic Fibers in the Post-Natal Mouse Brain. Front Cell Neurosci. 11:202. https://doi.org/10.3389/fncel.2017.00202

Marco I, Valhondo M, Martín-Fontecha M, et al. 2011. New serotonin 5-HT(1A) receptor agonists with neuroprotective effect against ischemic cell damage. J Med Chem. 54(23):7986-7999. https://doi.org/10.1021/jm2007886

Mauler F, Horváth E. 2005. Neuroprotective efficacy of repinotan $\mathrm{HCl}$, a 5-HT1A receptor agonist, in animal models of stroke and traumatic brain injury. J Cereb Blood Flow Metab. 25(4):451-459. https://doi.org/10.1038/sj.jcbfm.9600038

Matsuzaki H, Tamatani M, Mitsuda N, et al. 1999. Activation of Akt kinase inhibits apoptosis and changes in Bcl-2 and Bax expression induced by nitric oxide in primary hippocampal neurons. J Neurochem. 73(5):2037-2046.

McCorvy JD, Roth BL. 2015. Structure and function of serotonin G protein-coupled receptors. Pharmacol Ther.

150:129-142. https://doi.org/10.1016/j.pharmthera.2015.01.009

Meller E, Goldstein M, Bohmaker K. 1990. Receptor reserve for 5-hydroxytryptamine1Amediated inhibition of serotonin synthesis: possible relationship to anxiolytic properties of 5-hydroxytryptamine1A agonists. Mol Pharmacol. 37(2):231-237.

Mehta M, Ahmed Z, Fernando SS, Cano-Sanchez P, Adayev T, Ziemnicka D, Wieraszko A, Banerjee P. 2007a. Plasticity of 5-HT 1A receptor-mediated signaling during early postnatal brain development. J Neurochem. 101(4):918-28. https://doi.org/10.1111/j.1471-4159.2007.04448.x

Mehta SL, Manhas N, Raghubir R. 2007b. Molecular targets in cerebral ischemia for developing novel therapeutics. Brain Res Rev. 54(1):34-66. https://doi.org/10.1016/j.brainresrev.2006.11.003

Mishima K, Hayakawa K, Abe K, et al. 2005. Cannabidiol prevents cerebral infarction via a serotonergic 5-hydroxytryptamine1A receptor-dependent mechanism. Stroke. 36(5):1077-1082. https://doi.org/10.1161/01.STR.0000163083.59201.34

Miyazaki I, Asanuma M, Murakami S, et al. 2013. Targeting 5-HT(1A) receptors in astrocytes to protect dopaminergic neurons in Parkinsonian models. Neurobiol Dis. 59:244-256. https://doi.org/10.1016/j.nbd.2013.08.003

Miyazaki I, Asanuma M. 2016. Serotonin 1A Receptors on Astrocytes as a Potential Target for the Treatment of Parkinson's Disease. Curr Med Chem. 23(7):686-700. https://doi.org/10.2174/0929867323666160122115057

Moulaert VR, Wachelder EM, Verbunt JA, Wade DT, van Heugten CM. 2010. Determinants of quality of life in survivors of cardiac arrest. $J$ Rehabil Med. 42(6):553-558. https://doi.org/10.2340/16501977-0547

Mori MA, Meyer E, Soares LM, Milani H, Guimarães FS, de Oliveira RMW. 2017. Cannabidiol reduces neuroinflammation and promotes neuroplasticity and functional recovery after brain ischemia. Prog Neuropsychopharmacol Biol Psychiatry. 75:94-105. https://doi.org/10.1016/j.pnpbp.2016.11.005

Mogha A, Guariglia SR, Debata PR, Wen GY, Banerjee P. 2012. Serotonin 1A receptormediated signaling through ERK and PKCa is essential for normal synaptogenesis 
in neonatal mouse hippocampus. Transl Psychiatry. 2(1):e66. https://doi.org/10.1038/tp.2011.58

Nagakura A, Takagi N, Takeo S. 2002. Selective reduction in type I adenylyl cyclase after microsphere embolism in rat brain. Neurosci Lett. 317(2):69-72. https://doi.org/10.1016/s0304-3940(01)02421-1

National Institute of Neurological Disorders and Stroke rt-PA Stroke Study Group. 1995. Tissue plasminogen activator for acute ischemic stroke. $N$ Engl $J$ Med. 333(24):1581-1587. https://doi.org/10.1056/NEJM199512143332401

Nichols DE, Nichols CD. 2008. Serotonin receptors. Chem Rev. 108(5):1614-1641. https://doi.org/10.1021/cr078224o

Newman-Tancredi A, Kleven MS. 2011. Comparative pharmacology of antipsychotics possessing combined dopamine D2 and serotonin 5-HT1A receptor properties. Psychopharmacology (Berl). 216(4):451-473. https://doi.org/10.1007/s00213-011-2247-y

Newman-Tancredi, A. 2011. Biased agonism at serotonin 5-HT1A receptors: Preferential postsynaptic activity for improved therapy of CNS disorders. Neuropsychiatry, 1(2):149-164. https://doi.org/10.2217/npy.11.12

Newman-Tancredi A, Martel JC, Assié MB, et al. 2009. Signal transduction and functional selectivity of $\mathrm{F} 15599$, a preferential post-synaptic 5-HT1A receptor agonist. $\mathrm{Br} \mathrm{J}$ Pharmacol. 156(2):338-353. https://doi.org/10.1111/j.1476-5381.2008.00001.x

Nelson DL. 2004. 5-HT5 receptors. Curr Drug Targets CNS Neurol Disord. 3(1):53-8. https://doi.org/10.2174/1568007043482606.

Peroutka S. 1988. 5-Hydroxytryptamine Receptor Subtypes. Ann Rev Neurosc. 11:4560. https://doi.org/10.1146/annurev.ne.11.030188.000401

Pazos A, Cortés R, Palacios JM. 1985. Quantitative autoradiographic mapping of serotonin receptors in the rat brain. II. Serotonin-2 receptors. Brain Res. 346(2):231-249. https://doi.org/10.1016/0006-8993(85)90857-1

Palacios JM. 2016. Serotonin receptors in brain revisited. Brain Res. 1645:46-9. https://doi.org/10.1016/j.brainres.2015.12.042

Pang C, Cao L, Wu F, Wang L, Wang G, Yu Y, Zhang M, Chen L, Wang W, Lv W, Chen L, Zhu J, Pan J, Zhang H, Xu Y, Ding L. 2015. The effect of trans-resveratrol on post-stroke depression via regulation of hypothalamus-pituitary-adrenal axis. Neuropharmacology.

97:447-56. https://doi.org/10.1016/j.neuropharm.2015.04.017

Piera MJ, Beaughard M, Michelin MT, Massingham R. 1995. Effects of the 5hydroxytryptamine1A receptor agonists, 8-OH-DPAT, buspirone and flesinoxan, upon brain damage induced by transient global cerebral ischaemia in gerbils. Arch Int Pharmacodyn Ther. 329(3):347-359. https://doi.org/10.1016/00068993(85)90857-1

Pollak Dorocic I, Fürth D, Xuan Y, et al. 2014. A whole-brain atlas of inputs to serotonergic neurons of the dorsal and median raphe nuclei. Neuron. 83(3):663-678. https://doi.org/10.1016/j.neuron.2014.07.002

Polter AM, Li X. 2010. 5-HT1A receptor-regulated signal transduction pathways in brain. Cell Signal. 22(10):1406-1412. https://doi.org/10.1016/j.cellsig.2010.03.019 
Pratt GD, Bowery NG, Kilpatrick GJ, Leslie RA, Barnes NM, Naylor RJ, Jones BJ, Nelson DR, Palacids JM, Slater $P$, et al. 1990. Consensus meeting agrees distribution of 5-HT3 receptors in mammalian hindbrain. Trends Pharmacol Sci. 11(4):135-7. https://doi.org/10.1016/0165-6147(90)90058-g

Prehn JH, Backhauss C, Karkoutly C, et al. 1991. Neuroprotective properties of 5-HT1A receptor agonists in rodent models of focal and global cerebral ischemia. Eur $\mathrm{J}$ Pharmacol. 203(2):213-222. https://doi.org/10.1016/0014-2999(91)90717-5

Prehn JH, Welsch M, Backhauss $\mathrm{C}$, et al. 1993. Effects of serotonergic drugs in experimental brain ischemia: evidence for a protective role of serotonin in cerebral ischemia. Brain Res. 630(1-2):10-20. https://doi.org/10.1016/00068993(93)90636-2

Rajsic S, Gothe H, Borba HH, et al. 2019. Economic burden of stroke: a systematic review on post-stroke care. Eur $J$ Health Econ. 20(1):107-134. https://doi.org/10.1007/s10198-018-0984-0

Rapport MM, Green AA, Page IH. 1948. Serum vasoconstrictor, serotonin; isolation and characterization. J Biol Chem. 176(3):1243-1251.

Raymond JR, Mukhin YV, Gettys TW, Garnovskaya MN. 1999. The recombinant 5-HT1A receptor: $\mathrm{G}$ protein coupling and signalling pathways. $\mathrm{Br} J$ Pharmacol. 127(8):1751-1764. https://doi.org/10.1038/sj.bjp.0702723

Raval A.P., Liu C., Hu B.R. 2009. Rat Model of Global Cerebral Ischemia: The TwoVessel Occlusion (2VO) Model of Forebrain Ischemia. In: Chen J., Xu Z.C., Xu XM., Zhang J.H. (eds) Animal Models of Acute Neurological Injuries. Springer Protocols Handbooks. Humana Press. https://doi.org/10.1007/978-1-60327185-1_7

Rajkovic O, Potjewyd G, Pinteaux E. 2018. Regenerative Medicine Therapies for Targeting Neuroinflammation After Stroke. Front Neurol. 9:734. https://doi.org/10.3389/fneur.2018.00734

Ramos-Cabrer P, Campos F, Sobrino T, Castillo J. 2011. Targeting the ischemic penumbra. Stroke. $\quad 42(1 \quad$ Suppl):S7-11. https://doi.org/10.1161/STROKEAHA.110.596684.

Riad M, Garcia S, Watkins KC, Jodoin N, Doucet E, Langlois X, el Mestikawy S, Hamon $M$, Descarries L. 2000. Somatodendritic localization of 5-HT1A and preterminal axonal localization of 5 -HT1B serotonin receptors in adult rat brain. $J$ Comp Neurol. 417:181-94

Rewell SS, Churilov L, Sidon TK, et al. 2017. Evolution of ischemic damage and behavioural deficit over 6 months after MCAo in the rat: Selecting the optimal outcomes and statistical power for multi-centre preclinical trials. PLoS One. 12(2):e0171688. https://doi.org/10.1371/journal.pone.0171688

Roth BL, Berry SA, Kroeze WK, Willins DL, Kristiansen K. 1998. Serotonin 5-HT2A receptors: molecular biology and mechanisms of regulation. Crit Rev Neurobiol.12(4):319-338. https://doi.org/10.1615/critrevneurobiol.v12.i4.30

Rojas PS, Fiedler JL. 2016. What Do We Really Know About 5-HT1A Receptor Signaling in Neuronal Cells?. Front Cell Neurosci. 10:272. https://doi.org/10.3389/fncel.2016.00272 
Santarelli L, Saxe M, Gross C, et al. 2003. Requirement of hippocampal neurogenesis for the behavioral effects of antidepressants. Science. 301(5634):805-809. https://doi.org/10.1126/science.1083328

Salazar-Colocho P, Del Río J, Frechilla D. 2007. Serotonin 5-hT1A receptor activation prevents phosphorylation of NMDA receptor NR1 subunit in cerebral ischemia. $J$ Physiol Biochem. 63(3):203-211. https://doi.org/10.1007/BF03165783

Salazar-Colocho P, Del Río J, Frechilla D. 2008. Neuroprotective effects of serotonin 5HT 1A receptor activation against ischemic cell damage in gerbil hippocampus: Involvement of NMDA receptor NR1 subunit and BDNF. Brain Res. 1199:159-166. https://doi.org/10.1016/j.brainres.2007.12.032

Salminen A, Liu PK, Hsu CY. 1995. Alteration of transcription factor binding activities in the ischemic rat brain. Biochem Biophys Res Commun. 212(3):939-44. https://doi.org/10.1006/bbrc.1995.2060.

Sasaki T, Kitagawa K, Omura-Matsuoka E, et al. 2007. The phosphodiesterase inhibitor rolipram promotes survival of newborn hippocampal neurons after ischemia. Stroke. https://doi.org/10.1161/STROKEAHA.106.476754

38(5):1597-1605.

Semkova I, Wolz P, Krieglstein J. 1998. Neuroprotective effect of 5-HT1A receptor agonist, Bay X 3702, demonstrated in vitro and in vivo. Eur J Pharmacol. 359(23):251-260. https://doi.org/10.1016/s0014-2999(98)00634-7

Seino S, Miki T. 2003. Physiological and pathophysiological roles of ATP-sensitive $\mathrm{K}_{+}$ channels. Prog Biophys Mol Biol. 81(2):133-176. https://doi.org/10.1016/s00796107(02)00053-6

Soares LM, De Vry J, Steinbusch HWM, Milani H, Prickaerts J, Weffort de Oliveira RM. 2016. Rolipram improves cognition, reduces anxiety- and despair-like behaviors and impacts hippocampal neuroplasticity after transient global cerebral ischemia. Neuroscience.

326:69-83. https://doi.org/10.1016/j.neuroscience.2016.03.062

Schaper C, Zhu Y, Kouklei M, Culmsee C, Krieglstein J. 2000. Stimulation of 5-HT(1A) receptors reduces apoptosis after transient forebrain ischemia in the rat. Brain Res. 883(1):41-50. https://doi.org/10.1016/s0006-8993(00)02876-6

Schäbitz WR, Schwab S, Spranger M, Hacke W. 1997. Intraventricular brain-derived neurotrophic factor reduces infarct size after focal cerebral ischemia in rats. $J$ Cereb Blood Flow Metab. 17(5):500-6. https://doi.org/10.1097/00004647199705000-00003

Schmid CL, Raehal KM, Bohn LM. 2008. Agonist-directed signaling of the serotonin 2A receptor depends on beta-arrestin-2 interactions in vivo. Proc Natl Acad Sci U S A. 105(3):1079-1084. https://doi.org/10.1073/pnas.0708862105

Sniecikowska J, Newman-Tancredi A, Kolaczkowski M. 2019. From Receptor Selectivity to Functional Selectivity: The Rise of Biased Agonism in 5-HT1A Receptor Drug Discovery. Curr Top Med Chem. 19(26):2393-2420 . https://doi.org/10.2174/1568026619666190911122040

Sprouse JS, Aghajanian GK. 1986. (-)-Propranolol blocks the inhibition of serotonergic dorsal raphe cell firing by 5-HT1A selective agonists. Eur J Pharmacol. 128(3):295298. https://doi.org/10.1016/0014-2999(86)90782-x 
Takeo S, Niimura M, Miyake-Takagi K, et al. 2003. A possible mechanism for improvement by a cognition-enhancer nefiracetam of spatial memory function and cAMP-mediated signal transduction system in sustained cerebral ischaemia in rats. Br J Pharmacol. 138(4):642-654. https://doi.org/10.1038/sj.bjp.0705096

Tajiri N, Dailey T, Metcalf C, et al. 2013. In vivo animal stroke models: a rationale for rodent and non-human primate models. Transl Stroke Res. 4(3):308-321. https://doi.org/10.1007/s12975-012-0241-2

Tamatani M, Ogawa S, Niitsu Y, Tohyama M. 1998. Involvement of Bcl-2 family and caspase-3-like protease in NO-mediated neuronal apoptosis. $J$ Neurochem. 71(4):1588-1596. https://doi.org/10.1046/j.1471-4159.1998.71041588.x

Teal P, Silver FL, Simard D. 2005. The BRAINS study: safety, tolerability, and dosefinding of repinotan in acute stroke. Can J Neurol Sci. 32(1):61-67. https://doi.org/10.1017/s0317167100016899

Teal P, Davis S, Hacke W, et al. 2009. A randomized, double-blind, placebo-controlled trial to evaluate the efficacy, safety, tolerability, and pharmacokinetic/pharmacodynamic effects of a targeted exposure of intravenous repinotan in patients with acute ischemic stroke: modified Randomized Exposure Controlled Trial (mRECT). Stroke. 40(11):3518-3525. https://doi.org/10.1161/STROKEAHA.109.551382

Tingley WG, Ehlers MD, Kameyama K, et al. 1997. Characterization of protein kinase A and protein kinase $\mathrm{C}$ phosphorylation of the $\mathrm{N}$-methyl-D-aspartate receptor NR1 subunit using phosphorylation site-specific antibodies. J Biol Chem. 272(8):51575166. https://doi.org/10.1074/jbc.272.8.5157

Torup L, Møller A, Sager TN, Diemer NH. 2000. Neuroprotective effect of 8-OH-DPAT in global cerebral ischemia assessed by stereological cell counting. Eur J Pharmacol. 395(2):137-141. https://doi.org/10.1016/s0014-2999(00)00175-8

Thomas DR, Hagan JJ. 2004. 5-HT7 receptors. Curr Drug Targets CNS Neurol Disord. 3(1):81-90. https://doi.org/10.2174/1568007043482633.

Traystman RJ. 2003. Animal models of focal and global cerebral ischemia. ILAR J. 44(2):85-95. https://doi.org/10.1093/ilar.44.2.85

Twarog BM, Page IH. 1953. Serotonin content of some mammalian tissues and urine and a method for its determination. Am J Physiol. 175(1):157-161. https://doi.org/10.1152/ajplegacy.1953.175.1.157

van Goethem NP, Schreiber R, Newman-Tancredi A, Varney M, Prickaerts J. 2015. Divergent effects of the 'biased' 5-HT1 A receptor agonists F15599 and F13714 in a novel object pattern separation task. Br J Pharmacol.172(10):2532-2543. https://doi.org/10.1111/bph.13071

van Rooij FG, Schaapsmeerders P, Maaijwee NA, van Duijnhoven DA, de Leeuw FE, Kessels RP, van Dijk EJ. 2014. Persistent cognitive impairment after transient ischemic attack. Stroke. 45(8):2270-4 https://doi.org/10.1161/STROKEAHA.114.005205.

Verge D, Daval G, Patey A, Gozlan H, el Mestikawy S, Hamon M. 1985. Presynaptic 5HT autoreceptors on serotonergic cell bodies and/or dendrites but not terminals are of the 5-HT1A subtype. Eur $J$ Pharmacol. 113(3):463-464. https://doi.org/10.1016/0014-2999(85)90099-8 
Veerbeek JM, Kwakkel G, van Wegen EE, Ket JC, Heymans MW. 2011. Early prediction of outcome of activities of daily living after stroke: a systematic review. Stroke. 42(5):1482-1488. https://doi.org/10.1161/STROKEAHA.110.604090

Violin JD, Crombie AL, Soergel DG, Lark MW. 2014. Biased ligands at G-protein-coupled receptors: promise and progress. Trends Pharmacol Sci. 35(7):308-316. https://doi.org/10.1016/j.tips.2014.04.007

Wang RY, Aghajanian GK. 1977. Inhibiton of neurons in the amygdala by dorsal raphe stimulation: mediation through a direct serotonergic pathway. Brain Res. 120(1):85-102. https://doi.org/10.1016/0006-8993(77)90499-1

Walther DJ, Peter JU, Bashammakh S, et al. 2003. Synthesis of serotonin by a second $\begin{array}{lll}\text { tryptophan hydroxylase } \quad \text { isoform. Science. } & \text { 299(5603):76. }\end{array}$ https://doi.org/10.1126/science.1078197

Woolley ML, Marsden CA, Fone KC. 2004. 5-ht6 receptors. Curr Drug Targets CNS Neurol Disord. 3(1):59-79. https://doi.org/10.2174/1568007043482561

Whitaker-Azmitia PM, Clarke C, Azmitia EC. 1992. 5-HT1A immunoreactivity in brain astrocytes co-localized with GFAP. Synapse, 14: 201-205

Wu D, Pardridge WM. 1999. Neuroprotection with noninvasive neurotrophin delivery to the brain. Proc Natl Acad Sci $U$ S A. 96(1):254-259. https://doi.org/10.1073/pnas.96.1.254

Xu T, Pandey SC. 2000. Cellular localization of serotonin(2A) (5HT(2A)) receptors in the rat brain. Brain Res Bull. 51(6):499-505. https://doi.org/10.1016/s03619230(99)00278-6

Yamaguchi A, Tamatani M, Matsuzaki H, et al. 2001. Akt activation protects hippocampal neurons from apoptosis by inhibiting transcriptional activity of p53. J Biol Chem. 276(7):5256-5264. https://doi.org/10.1074/jbc.M008552200

Zaitseva T, Schears G, Schultz S, et al. 2005. Circulatory arrest and low-flow cardiopulmonary bypass alter CREB phosphorylation in piglet brain. Ann Thorac Surg. 80(1):245-250. https://doi.org/10.1016/j.athoracsur.2005.02.016

Zhao L, Liu X, Liang J, Han S, Wang Y, Yin Y, Luo Y, Li J. 2013 Phosphorylation of p38 MAPK mediates hypoxic preconditioning-induced neuroprotection against cerebral ischemic injury via mitochondria translocation of $\mathrm{Bcl}-\mathrm{xL}$ in mice. Brain Res. 1503:78-88. https://doi.org/10.1016/j.brainres.2013.01.051 


\section{CHAPTER 3}

\section{ACTIVATION OF 5-HT 1 A POSTSYNAPTIC RECEPTORS BY NLX-101 RESULTS IN FUNCTIONAL RECOVERY AND AN INCREASE IN NEUROPLASTICITY IN MICE WITH BRAIN ISCHEMIA}

Aguiar RP, Soares LM, Meyer E, Silveira FC, Milani H, Newman-Tancredi A, Varney M, Prickaerts J, de Oliveira RMW.

Progress in Neuro-Psychopharmacology \& Biological Psychiatry, 2020; 99:109832. Doi: 10.1016/j.pnpbp.2019.109832. 


\section{Abstract}

Pharmacological interventions that selectively activate serotonin 5-hydroxytryptramine$1 \mathrm{~A}\left(5-\mathrm{HT}_{1 \mathrm{~A}}\right)$ heteroreceptors may prevent or attenuate the consequences of brain ischemic episodes. The present study investigated whether the preferential $5-\mathrm{HT}_{1 \mathrm{~A}}$ postsynaptic receptor agonist NLX-101 (a.k.a. F15599) mitigates cognitive and emotional impairments and affects neuroplasticity in mice that are subjected to the bilateral common carotid artery occlusion (BCCAO) model of brain ischemia. The selective serotonin reuptake inhibitor escitalopram (Esc) was used for comparative purposes. Sham and BCCAO mice received daily doses of NLX-101 (0.32 mg/kg, i.p) or Esc (20 mg/kg, i.p) for 28 days. During this period, they were evaluated for locomotor activity, anxiety- and despair-related behaviors and hippocampus-dependent cognitive function, using the open field, elevated zero maze, forced swim test and object location test, respectivelly. The mice's brains were processed for biochemical and histological analyses. BCCAO mice exhibited high anxiety and despair-like behaviors and performed worse than controls in the cognitive assessment. BCCAO induced neuronal and dendritic spine loss and decreases in the protein levels of neuronal plasticity markers, including brain-derived neurotrophic factor (BDNF), synaptophysin (SYN), and postsynaptic density protein-95 (PSD-95), in prefrontal cortex (PFC) and hippocampus. NLX-101 and Esc attenuated cognitive impairments and despair-like behaviors in BCCAO mice. Only Esc decreased anxiety-like behaviors due to brain ischemia. Both NLX-101 and Esc blocked the increase in plasma corticosterone levels and, restored BDNF, SYN and PSD-95 protein levels in the hippocampus. Moreover, both compounds impacted positively dentritic remodeling in the hippocampus and PFC of ischemic mice. In the PFC, NLX-101 increased the BDNF protein levels, while Esc in turn, attenuated the decrease in the PSD-95 protein levels induced by BCCAO. The present results suggest that activation of post-synaptic $5-\mathrm{HT}_{1 \mathrm{~A}}$ receptors is the molecular mechanism for serotonergic protective effects in BCCAO. Moreover, post-synaptic biased agonists such as NLX-101 might constitute promising therapeutics for treatment of functional and neurodegenerative outcomes of brain ischemia.

Keywords: NLX-101; 5- $\mathrm{HT}_{1 \mathrm{~A}}$ receptor; brain ischemia; neuroprotection. 


\section{Introduction}

Cognitive dysfunction, anxiety, and depression are prominent symptoms of transient forms of brain ischemia (Ayerbe et al., 2013; Moulaert et al., 2010). These symptoms have been related to neuronal degeneration and a decline in synaptic plasticity that are induced by ischemic injury in the brain (Burns et al., 2009; Carmichael, 2011). Many pharmacological strategies have been tested for their ability to maintain normal neuronal activity, attenuate excitotoxicity, decrease neuroinflammation, attenuate apoptotic damage, and stimulate neuroplasticity and the structural remodeling of the dendritic tree in several brain structures that are affected by brain ischemia (Klisch et al., 2003; Sun et al., 2003; Tanaka et al., 2004; Schmidt and Minnerup, 2016; Sun et al., 2017). However, no effective therapy is currently available to promote recovery following brain ischemia. Despite this translational dilemma, the identification of new substances that are safe and effective to treat the sequelae of ischemic brain damage is imperative.

The selective reuptake serotonin inhibitors (SSRIs) such as fluoxetine, citalopram, and escitalopram (Esc) have been shown to improve clinical recovery and decrease disability in patients who survive brain ischemia (Dam et al., 1996; Zittel et al. 2008; Acler et al., 2009; Jorge et al., 2010; Chollet et al., 2011; Sunami et al., 2012; Mead et al., 2013; Siepmann et al., 2015). SSRls have also been shown to restore functional behaviors, reduce neuronal death, exert antiinflammatory effects, influence neurogenesis, and stimulate neuroplasticity in rodent models of global and focal brain ischemia (Kim et al., 2007; Lim et al., 2009; Lee et al., 2011; Dhami et al., 2013; Espinera et al., 2013). The neuroprotective effects of SSRIs on brain ischemia have been related to the activation of serotonin 5-hydroxytryptamine-1A (5- $\mathrm{HT}_{1 \mathrm{~A}}$ ) receptors (Bode-Greuel et al., 1990; Schaper et al., 2000; Klisch et al., 2003). Thus 5-HT1A receptor agonists have emerged as a potential target to promote neuroprotection in ischemic brain disease (Ramos et al., 2004; Pazos et al., 2013; Johansen et al., 2014; Hind et al., 2016). Linked to this, $5-\mathrm{HT}_{1 \mathrm{~A}}$ activation has been suggested to confer neuroprotection and cognitive improvement by influencing neurogenesis and dendritic remodeling after brain insult (Xu et al 2011; Marco et al., 2011; Campos et al., 2013; Chilmonczyk et al., 2017; Fogaça et al., 2018). 
Currently available 5- $\mathrm{HT}_{1 \mathrm{~A}}$ agonists, however, may have a limited therapeutic profile. They are poorly selective, only partially activate $5-\mathrm{HT}_{1 \mathrm{~A}}$ receptors (i.e. they are partial agonists) and they activate both inhibitory $5-\mathrm{HT}_{1 \mathrm{~A}}$ somatodendritic autoreceptors that are located on serotonergic cell bodies in raphe nuclei, and the $5-\mathrm{HT}_{1 \mathrm{~A}}$ postsynaptic heteroreceptors that are located in several brain regions, including the hippocampus, cortex, and amygdala (Pazos et al., 1985; Chalmers and Watson, 1991). Eventhough 5$\mathrm{HT}_{1 \mathrm{~A}}$ postsynaptic activation also presents inhibitory properties, it may differently stimulate diverse molecular signalling pathways as ERK and AKT, which can contribute for positive behavioral effects related to neuropsychiatric desorders (Albert and VahidAnsari, 2019). Also 5-HT 1 A receptor activation in these different brain regions has been shown to produce elements of serotonin behavioral syndrome (Arvidsson et al., 1981; Koek et al., 2001), induce hypothermia (Cryan et al., 1999), and increase plasma levels of corticosterone (Koek et al., 1998). Interestingly, the preferential activation of $5-\mathrm{HT}_{1 \mathrm{~A}}$ postsynaptic receptors has shown promising results in preclinical studies. The biased 5$\mathrm{HT}_{1 \mathrm{~A}}$ receptor agonist NLX-101 (a.k.a. F15599) has been shown to preferentially activate postsynaptic 5-HT ${ }_{1 A}$ receptors in cortical regions (Newman-Tancredi et al., 2009), ameliorate cognitive dysfunction (Depoortère et al., 2010), improve spatial pattern separation performance (Van Goethem et al., 2015), and exert potent antidepressantand anti-stress-like effects (Assié et al., 2010; Newman-Tancredi et al., 2011; Depoortère et al., 2019).

A pharmacological intervention that specifically activates $5-\mathrm{HT}_{1 \mathrm{~A}}$ postsynaptic receptors may thus achieve a positive pharmacological response to brain ischemia. The present study investigated whether the preferential $5-\mathrm{HT}_{1 \mathrm{~A}}$ postsynaptic receptor agonist NLX-101 mitigates cognitive and emotional impairments that are induced by brain ischemia in mice. We also evaluated the impact of NLX-101 treatment on key proteins that are related to synaptic plasticity, including brain-derived neurotrophic factor (BDNF), synaptophysin (SYN), and postsynaptic density protein-95 (PSD-95). In addition, we evaluated dendritic remodeling in the hippocampus and prefrontal cortex (PFC). To avoid possible short-term effects of NLX-101 on corticosterone levels as previously described (Assié et al., 2010), we started the drug treatments 1 week before surgery to stabilize the animals and minimize the number of variables that may affect the procedural outcomes. 
For comparative purposes, we included an experimental group that was treated with Esc, which has been previously shown to decrease morbidity and improve recovery in stroke patients and ischemic rodents (Lee et al., 2011; Siepmann et al., 2015).

\section{Material and Methods}

\section{Animals}

Male 3-month-old C57BL/6 mice (25-30 g; $n=101$ ) were obtained from the central vivarium of the State University of Maringá. The animals were acclimated to a controlled temperature $\left(22^{\circ} \pm 1^{\circ} \mathrm{C}\right)$ and a $12 \mathrm{~h} / 12 \mathrm{~h}$ light/dark cycle (lights on at 7:00 AM) for 2 weeks before the experiments. The animals were housed in groups ( $n=10-15 /$ group) in plastic cages ( $39 \times 32 \mathrm{~cm}$, with a height of $25 \mathrm{~cm}$ ) and given standard commercial chow (Nuvilab, Quimtia, PR, Brazil) and tap water ad libitum. The local Ethics Committee on Animal Experimentation of the State University of Maringá approved the experimental procedures in accordance with the guidelines of the U.S. National Institutes of Health and Brazilian College for Animal Experimentation (CEUA n. 7200220818). All efforts were made to minimize the number of animals used and their suffering.

\section{Surgery}

There are available diverse animal models to mimic some consequences of brain ischemic desease in humans. In this work we choose the model of bilateral common carotid artery occlusion (BCCAO), because it is generally applied to evaluate the effect of potential new treatments in neuronal injury, especially in the hippocampal and cortical regions, key components involved with behavioral effects of 5- $\mathrm{HT}_{1 \mathrm{~A}}$ postsynaptic receptor activation (Khodanovich \& Kisel et al., 2015). Transient global cerebral ischemia was induced by as previously described (Soares et al., 2016). The mice were anesthetized with a mixture of isoflurane (Isoforine, Cristália, SP, Brazil) and oxygen through a universal vaporizer (Oxigel, SP, Brazil). The vaporizer was regulated to release the minimal burble flow $(2.0 \mathrm{~L} / \mathrm{min})$. Under these conditions, the animals were fixed in a stereotaxic frame, and anesthesia was maintained with $1.3-1.5 \%$ isoflurane in $100 \%$ oxygen for 6 min, during which time an incision was made in the ventral neck to expose the common carotid arteries. Rectal temperature was monitored during surgery and 
maintained at $37.5^{\circ} \mathrm{C}$ using a heating blanket. BCCAO was induced for 20 min using aneurysm clips (ADCA, Belo Horizonte, MG, Brazil). During occlusion, the mice were maintained in a warming box ( $30^{\circ} \mathrm{C}$ inner temperature) to avoid ischemia-induced cerebral hypothermia. At the end of each occlusion, the aneurism clips were removed, and the carotid arteries were visually inspected for reperfusion. Each animal was then anesthetized again for $2 \mathrm{~min}$, and the incision was closed with sutures. Sham-operated animals were subjected to the same anesthetic and surgical interventions, with the exception that the carotid arteries remained intact.

\section{Drugs}

Escitalopram (Prati \& Donaduzzi, Toledo, PR, Brazil), NLX-101 (Neurolixis, Dana Point, CA, USA), or vehicle (Veh; $0.9 \%$ saline) were administered intraperitoneally (i.p.) once daily (between 4:00 PM and 5:00 PM) for 1 week before surgery and for 21 days after surgery. The doses of Esc (20 mg/kg) and NLX-101 $(0.32 \mathrm{mg} / \mathrm{kg})$ were based on previous studies that showed positive effects regarding molecular and behavioral responses in rodents (Assié et al., 2010; Lee et al., 2011). All of the drug solutions were prepared fresh daily and injected in a volume of $10 \mathrm{ml} / \mathrm{kg}$. The animals were randomly assigned to the following treatment groups in a counterbalanced order: Sham + Veh, BCCAO + Veh, BCCAO + Esc, and BCCAO + NLX-101.

\section{Experimental Design}

Behavioral testing was conducted from 7:00 AM to 1:00 PM. The open field test (OF), elevated zero maze (EZM), object location test (OLT), and forced swim test (FST) were performed on days 7, 8, 14, and 21 after surgery, respectively (Fig. 1). All of the animals' behaviors were recorded and analyzed using the ANYmaze contrast-sensitive video monitoring system (Stoelting, Wood Dale, IL, USA). After behavioral testing and 24 $\mathrm{h}$ after the last drug injection, all of the animals were deeply anesthetized, and blood and brains were removed and processed for biochemical and histological analyses. 


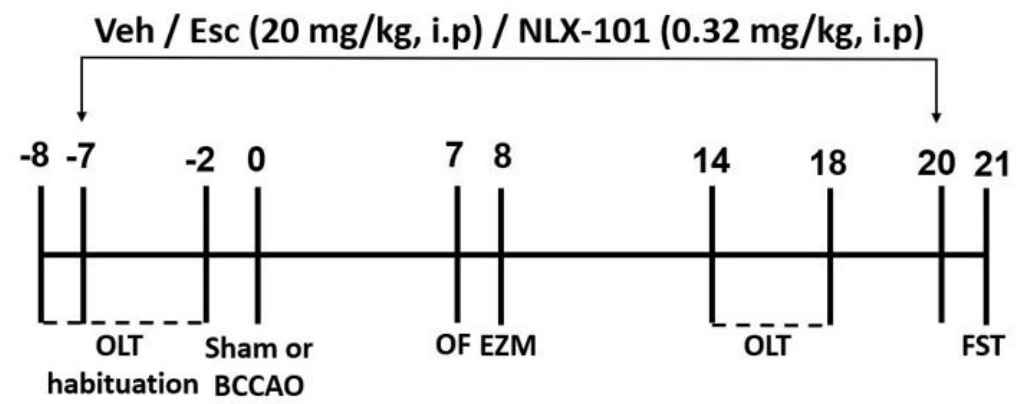

Figure 4: Experimental design. Escitalopram (Esc), NLX-101 or vehicle (Veh; saline $0.9 \%$ ), were intraperitoneal (i.p) administered one week before and during 21 days after sham or bilateral common carotid artery occlusion (BCCAO) surgeries. The open field test, (OF), elevated zero maze (EZM), object location test (OLT) and forced swimming test (FST) were performed at $7^{\text {th }}, 8^{\text {th }}, 14^{\text {th }}$ and $21^{\text {th }}$ days after the surgery. After behavioral testing, the brains were adequately removed and assayed for biochemical and histological analysis.

\section{Behavioral testing}

Open field test

The OF evaluates locomotion and exploration (Gellért \& Varga, 2016). The open field consisted of a wooden square box $(70 \mathrm{~cm} \times 70 \mathrm{~cm})$ with $40 \mathrm{~cm}$ high walls. On day 7 after BCCAO, each mouse was gently taken from its home cage, immediately placed in the center of the open field, and allowed to explore the box for $10 \mathrm{~min}$. The distance traveled (in meters) was recorded.

\section{Elevated zero maze}

The EZM is a modification of the elevated plus maze, with the advantage of lacking the ambiguous central area of the elevated plus maze (Kulkarni et al., 2007). The EZM test is based on two conflicting innate tendencies of rodents: exploring a novel environment and avoiding elevated and open spaces that constitute situations of predator risk. The apparatus consisted of a ring-shaped runway (46 cm diameter, $5.5 \mathrm{~cm}$ width) that was made from gray plastic material and elevated $20 \mathrm{~cm}$ above the floor. The runway was divided into two opposing open quadrants and two opposing closed quadrants with sidewalls ( $11 \mathrm{~cm}$ height). On day 8 after BCCAO, each mouse was individually placed on one of the open quadrants where it was allowed to explore the apparatus for 6 min under low light conditions. The number of entries into and time spent in the open quadrants of 
the EZM were recorded to calculate the percentage of open-quadrant entries and percent time in the open quadrants.

\section{Object location test}

The OLT assesses cognition, specifically spatial memory and discrimination in rodent models of central nervous system-related disorders. This test is based on the spontaneous tendency of rodents to recognize when an object has been relocated (Denninger et al., 2018). Testing occurs in an open field arena, to which the animals were first habituated. The apparatus consisted of a circular arena $(43 \mathrm{~cm}$ diameter with $40 \mathrm{~cm}$ high walls) that was made of transparent polyvinyl chloride. Three different sets of objects were used, and each object was available in triplicate. The different objects were (1) an aluminum cube with a tapering top $(4.5 \mathrm{~cm} \times 4.5 \mathrm{~cm} \times 8.5 \mathrm{~cm})$, (2) a glass $200 \mathrm{ml}$ bottle that was filled with water ( $5.5 \mathrm{~cm}$ diameter, $15.0 \mathrm{~cm}$ height), and (3) a porcelain cube $(9.5$ $\mathrm{cm} \times 6.5 \mathrm{~cm} \times 6.5 \mathrm{~cm}$ ). These objects were fixed within the apparatus and could not be moved by the mouse. One week before BCCAO, the animals were familiarized with the OLT, in which they were initially allowed to explore the circular arena (without any objects) on two consecutive days ( $3 \mathrm{~min} /$ day). On the following 4 days, the mice were trained with the objects until they presented stable discrimination performance, indicated by good object discrimination at a 1-h interval. Subsequently, BCCAO was induced, and then the OLT was performed on days 14 and 18 after surgery at 1 and $4 \mathrm{~h}$ intervals. The test session consisted of two trials. Each trial lasted 3 min. During the first trial (T1), the arena contained two identical objects. The mouse was introduced to the arena for the first exploration period. The animal was then returned to its home cage. After the predetermined time interval ( 1 and $4 \mathrm{~h}$ ), the mouse was returned to the arena with the same objects for the second trial (T2), but one of the objects was relocated in this trial. The time spent exploring the two objects during $\mathrm{T} 1$ and $\mathrm{T} 2$ was recorded manually by an experienced observer who was blind to treatment conditions. The discrimination index (D2), an indication of spatial memory, was calculated to indicate whether the mouse spent more time exploring the relocated object, while correcting for the total exploration time in T2. D2 = (exploration timenovel location - exploration timefamiliar location) / (exploration timenovel location + exploration timefamiliar location). Thus, even if a treatment affected exploratory 
behavior, D2 would be comparable between conditions. Exploratory behavior was defined as the following: the mouse directing its nose to the object at no more than $1 \mathrm{~cm}$ and/or touching the object with its nose. Sitting on the object was not considered exploration. Animals that explored the objects $<5 \mathrm{~s}$ were excluded from the analysis because sufficient exploratory behavior is required to achieve a reliable measure of memory performance. The order of the objects, which object was moved, and the position where the object was relocated were balanced throughout the experiment and between groups to reduce potential bias toward particular objects, sides, or locations.

\section{Forced swim test}

The FST is commonly used to study passive coping strategies in rodents (Can et al., 2012). In this task, the mice are subjected to one trial, during which they are forced to swim in an acrylic cylinder that is filled with water at $25^{\circ} \mathrm{C}$, from which they cannot escape. The time that the animal spends without making any movements beyond those required to keep its head above water is measured. Briefly, on day 22 after BCCAO, each mouse was individually placed in an acrylic cylinder $(10 \mathrm{~cm}$ diameter, $25 \mathrm{~cm}$ height) that contained enough water, so the mouse could not touch the bottom of the container or escape. Each session was recorded using a video camera. The latency to the first episode of immobility and total immobility time, during which the mouse did not struggle and only made movements that were necessary to keep its head above water, were measured during a 6-min swim session.

\section{Biochemical analyses}

Tissue preparation

The animals were decapitated on day 21 between 1:00 PM and 4:00 PM under i.p. sodium thiopental anesthesia (Thiopentax, Cristália, SP, Brazil). Blood was collected ( $n=4 /$ group) by puncturing the posterior vena cava and then centrifuged at 2000 rotations per minute for $15 \mathrm{~min}$. After centrifugation, plasma was separated and stored at $-80^{\circ} \mathrm{C}$ for the subsequent determination of corticosterone levels using an enzyme-linked immunosorbent assay (ELISA). The prefrontal cortex (PFC) and hippocampus were rapidly dissected ( $n=5-6 /$ group) according to Spijker (2011). The samples were lysed in 
tissue buffer that contained $50 \mathrm{mM}$ Tris $(\mathrm{pH} 7.6)$ and complete proteinase inhibitor (1:10 dilution of stock solution; Sigma-Aldrich, St. Louis, MO, USA). After the samples were centrifuged at $2000 \mathrm{rpm}$, the supernatant was collected and stored at $-80^{\circ} \mathrm{C}$ until further use to determine the levels of BDNF by ELISA and synaptic proteins (PSD-95 and synaptophysin) and NeuN by Western blot.

\section{Plasma corticosterone levels}

Plasma corticosterone levels were determined by ELISA, with the aid of an immunoenzymatic reaction kit according to the manufacturer's instructions (DetectX, Arbor Assays, Eisenhower Place, Ann Arbor, MI, USA). Briefly, a plasma sample (5 $\mu \mathrm{l})$ was treated with $5 \mu \mathrm{l}$ of dissociation reagent for $10 \mathrm{~min}$ and diluted to 1:100. The samples were run in duplicate with a sheep polyclonal antibody against corticosterone in a 96-well immunoplate. A microplate reader (AsysExpert Plus, Biochrom, Berlin, Germany) was used to measure the intensity of immunofluorescence at $450 \mathrm{~nm}$ for standards and all of the samples. Standard curves were created using online software (http://www.myassays.com) and used to determine corticosterone concentrations (pg/ml) in the experimental samples.

\section{BDNF levels}

Total proteins of the samples were quantified using the Bradford method (Bio-Rad Laboratories, Hercules, CA, USA) and then analyzed by ELISA to detect BDNF using an immunoenzymatic reaction kit according to the manufacturer's instructions (BDNF Emax ImmunoAssay System, Promega, Madison, WI, USA). Briefly, 96-well immunoplates were coated with monoclonal anti-mouse-BDNF antibody at $100 \mu \mathrm{l} /$ well. After overnight incubation at $4^{\circ} \mathrm{C}$, the plates were washed three times with wash buffer. The samples were diluted 1:5 in Dulbecco's PBS and acidified (to approximately $\mathrm{pH} 2.6$ ) with $\mathrm{HCl} 1 \mathrm{~N}$ by 15 min to be incubated in the coated wells (100 $\mu$ each) for $2 \mathrm{~h}$ at room temperature with shaking. After five additional washes, the immobilized antigen was incubated with an anti-human BDNF antibody for $2 \mathrm{~h}$ at room temperature with shaking. The plates were washed again with wash buffer and then incubated with anti-immunoglobulin $Y(\lg Y)$ horseradish peroxidase for $1 \mathrm{~h}$ at room temperature. After another wash, the plates were 
incubated with a TMB/peroxidase substrate solution for $15 \mathrm{~min}$, and $1 \mathrm{M}$ phosphoric acid (100 $\mu \mathrm{l} /$ well) was added to the wells. The calorimetric reaction product was measured at $450 \mathrm{~nm}$ using a microplate reader (Asys Expert Plus, Biochrom, Berlin, Germany). BDNF concentrations ( $\mathrm{pg} / \mathrm{\mu g}$ of total protein) were determined from the regression line for the BDNF standard (ranging from 7.8 to $500 \mathrm{pg} / \mathrm{ml}$ purified mouse BDNF) that was incubated under similar conditions in each assay. All of the assays were performed in duplicate.

\section{Western blot}

Protein concentrations in the stored supernatant from the PFC and hippocampus were determined using the Bradford method (Bio-Rad, Hercules, CA, USA). Proteins (30 $\mu \mathrm{g}$ from each sample well) were isolated, electrophoresed, and immunoblotted on a $10 \%$ sodium dodecyl sulfate-polyacrylamide gel. After protein transfer onto a nitrocellulose membrane (Bio-Rad, Hercules, CA, USA), the membranes were blocked ( $2 \%$ bovine serum albumin in TBS buffer) and incubated with the primary antibody at $4^{\circ} \mathrm{C}$ overnight at the following dilutions: anti-NeuN (1:500; Abcam, Cambridge, MA, USA), antisynaptophysin, presynaptic protein (1:2500; Millipore), anti-PSD-95, postsynaptic protein (1:2000; QED Bioscience, San Diego, CA, USA), and anti-GAPDH (1:2500; Santa Cruz Biotechnology, Santa Cruz, CA, USA). After a washing step with TBS, the membranes were incubated for $2 \mathrm{~h}$ with donkey anti-mouse IgG (1:2000; Abcam, Cambridge, MA, USA). Reactive bands were detected using enhanced chemiluminescence reagent (ECLplus, Invitrogen, Carlsbad, CA, USA) and visualized using the ChemiDoc Imaging System (Bio-Rad, Hercules, CA, USA). Intensities of specific bands were quantified using ImageJ software (National Institutes of Health, Bethesda, MD, USA) and normalized to GAPDH protein levels. The data are presented as a percentage of the Sham + Veh group (control).

\section{Golgi-Cox staining}

Additional groups of matched C57BL/6 mice were used for Golgi-Cox staining ( $n$ $=7 /$ group). Following complete anesthesia with i.p. sodium thiopental (Thiopentax, Cristália, SP, Brazil), the animals were transcardially perfused with $0.1 \mathrm{M}$ phosphatebuffered saline for $3 \mathrm{~min}$ at a flow rate of $22 \mathrm{ml} / \mathrm{min}$. The brains were collected and stored 
in small amber tubes that contained $10 \mathrm{ml}$ of Golgi solution for $24 \mathrm{~h}$ and incubated for $24 \mathrm{~h}$ at $37^{\circ} \mathrm{C}$. After this time, the Golgi solution was replaced by a new solution ( $10 \mathrm{ml}$ ), and the brains were stored for 20 days at room temperature while protected from light. Before the brains were frozen in liquid nitrogen, they were exposed to a concentrated sucrose solution $(30 \% ; 10 \mathrm{ml})$ and then sliced in a $1: 2$ series into $100 \mu \mathrm{m}$ coronal sections from the PFC (+3.20 to $+1.70 \mathrm{~mm}$ from bregma; Paxinos and Franklin, 2001) to the ventral hippocampus (-1.34 to $-3.08 \mathrm{~mm}$ from bregma; Paxinos and Franklin, 2001) using a cryostat (Criocut 1800 , Reichert-Jung, Heidelberg, Germany) at $-21^{\circ} \mathrm{C}$. The sections were mounted onto gelatin-coated slides. The sections were then washed with $\mathrm{dH}_{2} \mathrm{O}$ for 5 min and alkalinized into 30\% ammonium hydroxide solution in $\mathrm{dH}_{2} \mathrm{O}(2: 1$, SigmaAldrich, Saint Louis, MO, USA) for $40 \mathrm{~min}$. The sections were washed in $\mathrm{dH} 2 \mathrm{O}$ for an additional 5 min and developed in Kodak Rapid Fix solution that was prepared according to the manufacturer's instructions, with solution B omitted (catalog no. 5160353, Kodak, Rochester, NY, USA). The sections were washed in $\mathrm{dH}_{2} \mathrm{O}$ for an additional $5 \mathrm{~min}$ and passed through an ascending series of alcohol concentrations (50\%,70\%,95\%, and $100 \%$ ) and placed in xylene for 20 min, followed by cover slipping with DPX medium (Fisher Chemical, São Paulo, SP, Brazil).

Golgi-Cox impregnated neurons located in the PFC (pyramidal neurons - layers III and V; Fig. 5A-D) and dentate gyrus of the hippocampus (granular neurons; Fig. 5L-O) were analyzed using an Olympus AX-70 light microscope (Olympus, Tokyo, Japan). One experimenter blind to experimental conditions measured the total length of the dendritic tree, the number of branches and the number of dendritic spines in $30 \mu \mathrm{m}$ - secondary branches, because second-order dendritic ramifications are particularly sensitive to plastic changes (Gould et al., 1990; Pyapali and Turner, 1994). Neurons were traced by ImageJ/FIJI software with NeuronJ plugin (National Institute of Health, Bethesda, MD, USA) according Meijering, 2010. Five neurons per animal were analyzed in different sections using the following criteria: the neurons were relatively isolated, displayed a defined cell body and a complete dendritic tree evidenced by well-defined endings, and presented intact branches.

\section{Statistical analyses}


SPSS 20 Statistic software (IBM® corp. Armonk, NY, USA) was used for the statistical analysis, and GraphPad Prism software version 6.0 (San Diego, California, USA) was used to graphical illustrations. To analyse the mortality rate, a proportion-like $t$-test was used to evaluate the confidence intervals to estimate the difference between two population proportions. Behavioral data were examined for assumptions of normal distribution (D'Agostino and Pearson omnibus test) and homoscedasticity (Levene's test). Since behavioral data followed normal distribution and homoscedasticity, one-way ANOVA was used for between-group comparisons. If a main effect of group was found, a Newman-Keuls multiple range test was used to distinguish between them. Functional spatial memory within the groups, i.e., a D2 value in the OLT that differs significantly from 0 was analyzed with a two-way one-sample $t$-test. Because the results of morphological and molecular analysis did not attend the normal distributition and the homocedasticity consistently, the generalized linear model with a Poisson distribution was used for the not countiuous data (i.e., Golgi-cox analysis) and the generalized linear model with a Gamma distribution was used for the continuous data (i.e., ELISA and Western blot). Values of $p$ $\leq 0.05$ were considered statistically significant.

\section{RESULTS}

\section{Mortality rate}

Overall, 101 animals entered the experiment. The proportion-like $t$-test showed significant difference between Sham + Veh and BCCAO + Veh groups $(p<0.01)$ concerning the mortality rate (Table 1 ). No significant difference was observed with the $B C C A O+E s c(p=0.09)$ or BCCAO + NLX-101 $(p=0.92)$ groups as compared with $B C C A O+$ Veh group, indicating that treatment with Esc or NLX-101 did not protect the animals from the effects of BCCAO on mortality.

Table 3: Mortality Rate. A proportion-like $t$-test was used to evaluate the confidence intervals to estimate the difference between two population proportions. ${ }^{*} p<0.05$ vs. Sham + Veh group. 


\begin{tabular}{|c|c|c|c|c|}
\hline Group & $\mathbf{n}$ & Deaths & $\%$ & $\begin{array}{c}\text { Proportion- } \\
\text { like t-test }\end{array}$ \\
\hline Sham + Veh & 15 & 0 & 0 & - \\
\hline BCCAO + Veh & 31 & 13 & 41.90 & $p<0.01^{*}$ \\
\hline BCCAO + Esc & 28 & 6 & 21.40 & $p=0.09$ \\
\hline BCCAO + NLX-101 & 27 & 11 & 40.70 & $p=0.92$ \\
\hline
\end{tabular}

\section{Behavioral testing}

Esc but not NLX-101 prevents expression of anxiety-like behaviors in BCCAO mice.

As shown in Fig. $2 \mathrm{~A}$, there was no difference in the total distance traveled in the OF among the experimental groups $\left(F_{3,35}=0.34 ; p=0.79\right)$. In the EZM test, the \% of entries in the open quadrants of the EZM was not altered by ischemia or treatment $\left(\mathrm{F}_{3,35}\right.$ $=0.16 ; p=0.91 ;$ Fig $2 B$ ). However, between-group differences appeared in the $\%$ of time spent in the open quadrants of the maze $\left(\mathrm{F}_{3,35}=4.95 ; \mathrm{p}<0.01\right.$; Fig. $2 \mathrm{C}$. Compared to sham animals, the BCCAO + Veh group presented a decrease in the \% of time $(p<0.05)$, indicating anxiogenic-like effect of brain ischemia. This effect of ischemia was prevented by Esc $(p<0.05$ vs. vehicle).

EsC and NLX-101 attenuate cognitive impairments induced by BCCAO in mice

Based on relative D2 discrimination index intervals in the OLT, ANOVA revealed significant effect at $1-h\left(F_{3,35}=4.80 ; p<0.01\right.$; Fig. $\left.2 D\right)$ and 4-h $\left(F_{3,35}=5.00 ; p<0.01\right.$ Fig. $2 \mathrm{E}$ ) intervals. In both 1 and 4-h intervals, BCCAO + Veh group showed a decrease in the relative D2 discrimination index as compared to Sham group $(p<0.05)$. At $1-h$ and $4-h$ intervals, BCCAO + Esc and BCCAO + NLX-101 groups exhibited an increase in D2 scores as compared to the BCCAO + Veh group $(p<0.05)$. We also observed that at $1-$ $h$ interval Sham + Veh $\left(t_{15}=4.48 ; p<0.01\right)$, BCCAO + Esc $\left(t_{15}=2.09 ; p<0.05\right)$ and $\mathrm{BCCAO}+\mathrm{NLX}-101\left(\mathrm{t}_{15}=2.31 ; \mathrm{p}<0.05\right)$ groups showed D2 scores different from zero, indicating they could distinguish between the familiar and the novel location while BCCAO + Veh group could not $(p>0.05)$. Furthermore, at 4-h interval Sham + Veh $\left(t_{15}=3.21 ; p\right.$ $<0.01)$ and $\mathrm{BCCAO}+\mathrm{NLX}-101\left(\mathrm{t}_{15}=7.99 ; \mathrm{p}<0.01\right)$ while $\mathrm{BCCAO}+\mathrm{Veh}$ and BCCAO + Esc group did not $(p>0.05)$. 

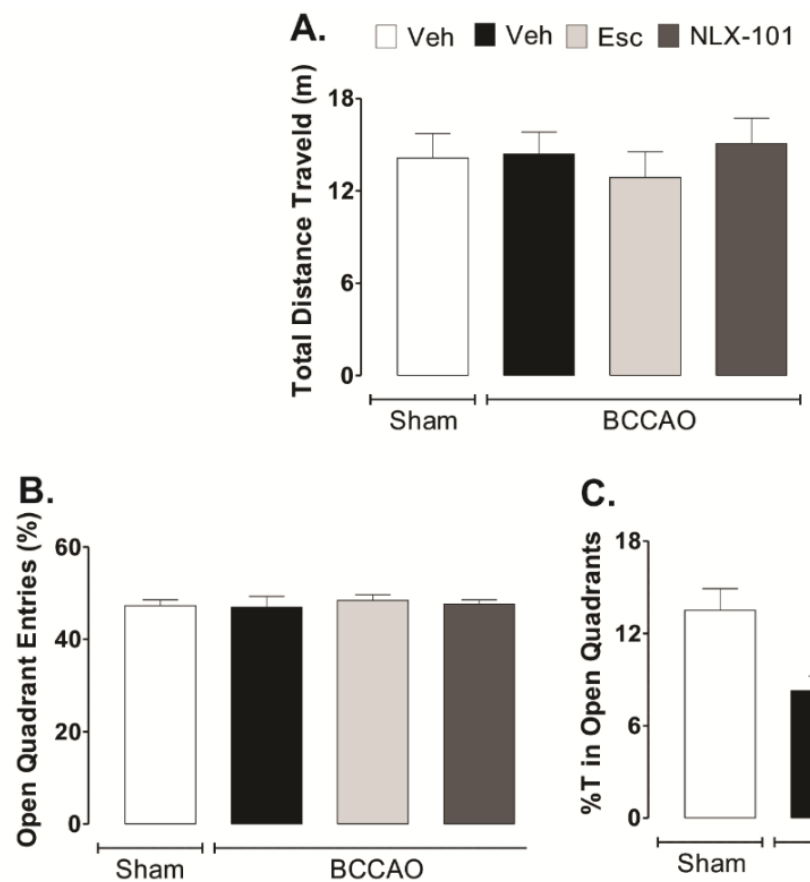

C.

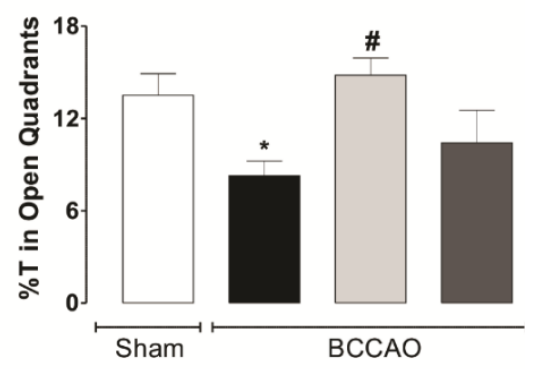

D.

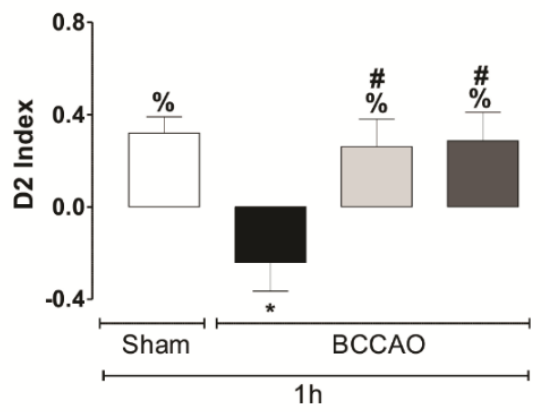

E.

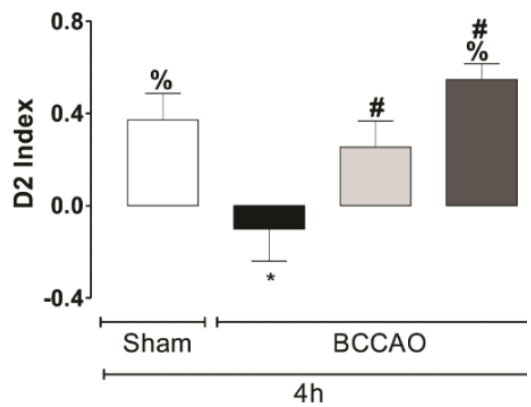

F.

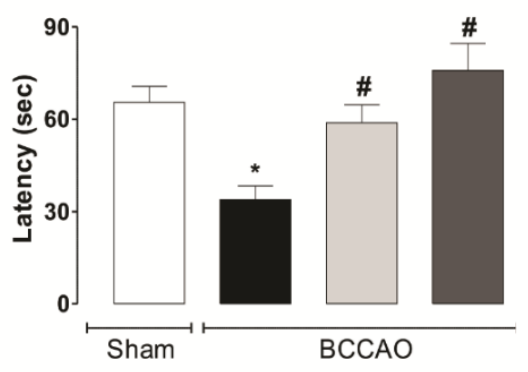

Figure 5: Esc and NLX-101 promote functional recovery in BCCAO mice. (A) Open field task (OF). (B) Open quadrants entries (\%) in the elevated zero maze (EZM). (C) \% Time (T) in open quadrants in the EZM. (D) $1 \mathrm{~h}$ and (E) $4 \mathrm{~h}$ interval in the object location test (OLT). (F) Latency for the first episode of immobility in the forced swimming test (FST). Memory was evaluated by the time of finding objects using the exploration index D2 (D2 = 80 [scan time at the new location - scan time at the family location] / [scan time at the new location + scan time at the family location]) at different time intervals. Bars 
represent mean \pm S.E.M of the different groups $\left(n=8,10,13,8\right.$ / group, respectively). ${ }^{*} p$ $<0.05$ vs. Sham + Veh; ${ }^{\#} p<0.05$, vs. BCCAO + Veh; $\%$ D2 index $\neq 0$.

ESC and NLX-101 improve passive coping strategies of BCCAO mice in the FST

ANOVA revealed significant difference in the latency for the first immobility episode in the FST $\left(F_{3,35}=7.94 ; p<0.01\right.$; Fig. $\left.2 F\right)$. The BCCAO + Veh group presented lower latency when compared to Sham + Veh $(p<0.05)$, an effect that was reversed by Esc or NLX-101 ( $p<0.05$ vs. vehicle).

\section{Biochemical and histological analysis}

ESC and NLX-101 decrease basal plasma corticosterone levels in BCCAO mice

The results of the plasma corticosterone levels are illustrated in Fig. 3. Significant differences were observed among the BCCAO groups $\left(\chi^{2}=13.44 ; p<0.05\right)$. Ischemic animals presented a significant elevation in the plasma corticosterone levels $(p<0.05)$ when compared to controls, while Esc and NLX-101 $(p<0.01)$ prevented this effect.

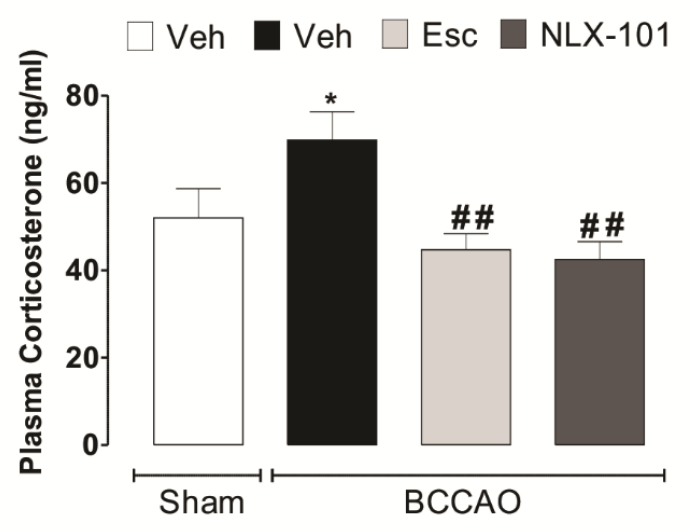

Figure 6: Esc and NLX-101 decrease basal plasma corticosterone levels in BCCAO mice. Bars represent mean \pm S.E.M of the different groups ( $n=4 /$ group). ${ }^{*} p<0.05$ vs. Sham + Veh; ${ }^{\#} p<0.01$ vs. BCCAO + Veh group.

EsC and NLX-101 affect BDNF protein levels in the PFC and hippocampus of BCCAO mice.

There was significant difference in the BDNF protein levels among the experimental groups in the hippocampus $\left(\chi^{2}=29.56\right.$; $p<0.01$; Fig. $\left.4 \mathrm{~B}\right)$, but only marginally in the PFC $\left(\chi^{2}=6.63 ; p=0.05\right.$; Fig. $\left.4 A\right)$. BCCAO + Veh animals presented a 
decrease in the BDNF levels in the PFC $(p<0.05)$ and hippocampus $(p<0.01)$ when compared to sham operated animals. In the hippocampus, the BDNF protein levels were restored in ischemic animals treated with both Esc $(p<0.01)$ or NLX-101 $(p<0.01)$ groups. NLX-101 also restored the BDNF protein levels in the PFC $(p<0.05)$.

A.

Veh

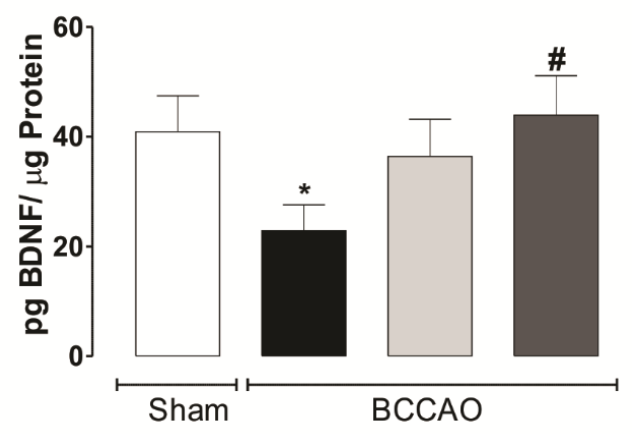

B.

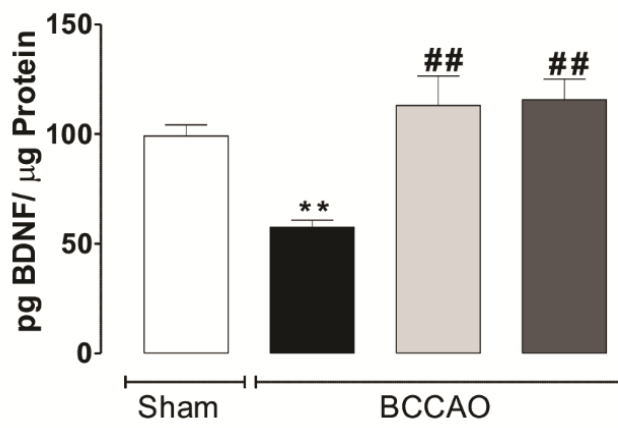

Figure 7: Esc and NLX-101 affect brain derived neurotrophic factor (BDNF) protein levels in the prefrontal cortex (PFC) and hippocampus in BCCAO mice. BDNF protein levels in the (A) PFC and (B) hippocampus. Bars represent mean \pm S.E.M of the different groups ( $n=5$ /group). ${ }^{*} p<0.05$ vs. Sham + Veh; ${ }^{\#} p<0.05,{ }^{\#} p<0.01$ vs. BCCAO + Veh group.

EsC and NLX-101 impact dendritic remodeling in the PFC and hippocampus of BCCAO mice.

Fig. 5 shows the results of dendritic remodeling in ischemic mice after Esc or NLX101 treatment in PFC and hippocampus. In the PFC, there were significant differences among experimental groups concerning the total dendritic length $\left(\chi^{2}=367 ; p<0.01\right.$; Fig. $5 \mathrm{I})$ and number of apical $\left(\chi^{2}=10.74 ; p<0.05\right.$; Fig. $\left.5 \mathrm{~K}\right)$ and basilar $\left(\chi^{2}=7.53 ; p<0.05\right.$; Fig. $5 \mathrm{~K}$ ) spines in the pyramidal neurons. Compared to Sham + Veh group, BCCAO mice presented a significant reduction in the total dendritic length $(p<0.01)$ which was prevented by Esc or NLX-101 treatment $(p<0.01)$. Also, BCCAO induced a decrease in the number of apical and basilar spines as compared to controls $(p<0.05)$. Esc or NLX101 treatment did not affect the loss of apical spines in BCCAO mice $(p>0.05)$. However, ischemic animals that received Esc or NLX-101 presented a partly attenuation of the loss of basilar spines as this measure was not different from Sham + Veh $(p=0.07$ and 0.26 , 
respectively), though also not different from BCCAO + Veh still (0.37 and 0.10, respectively)

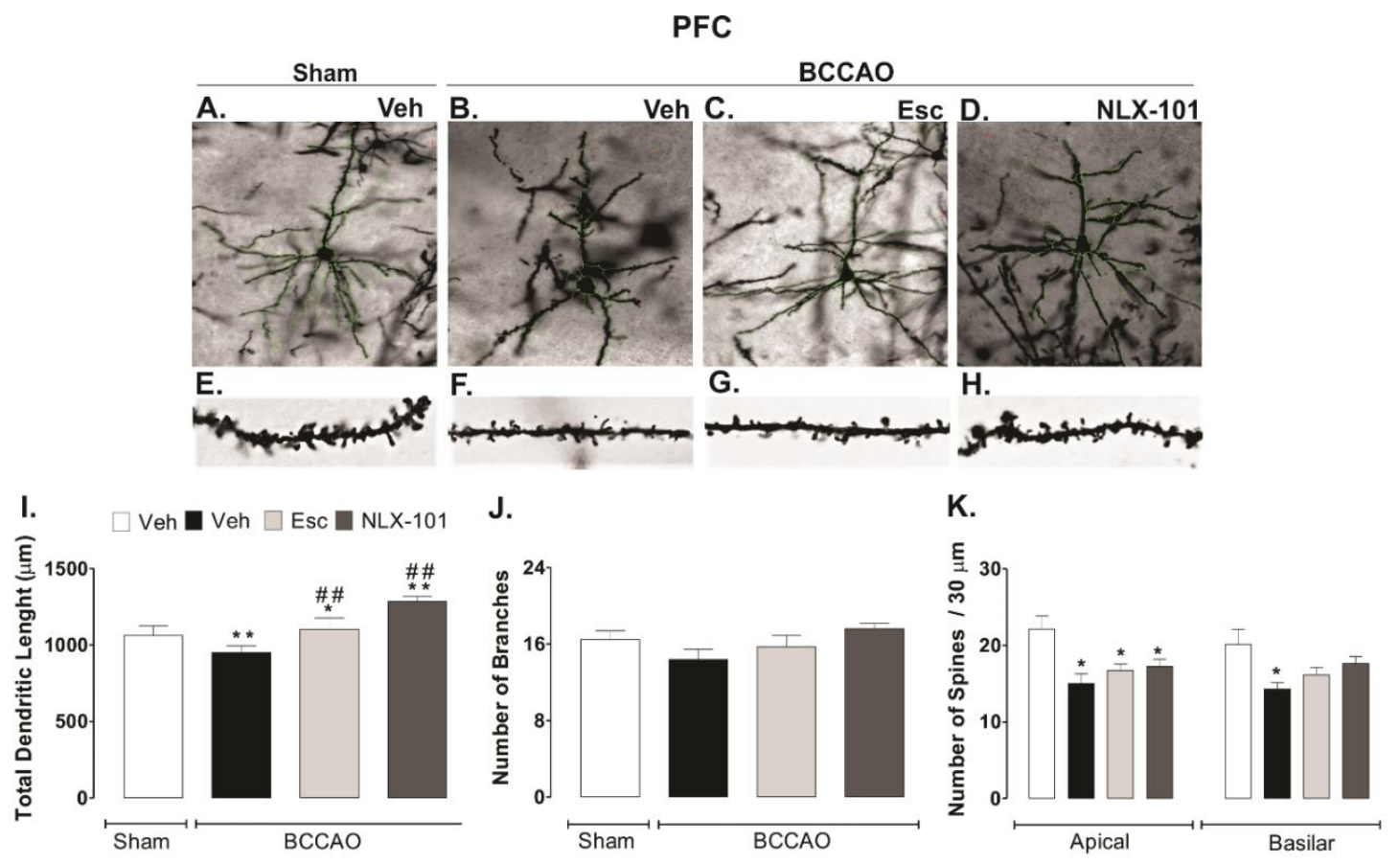

Hippocampus

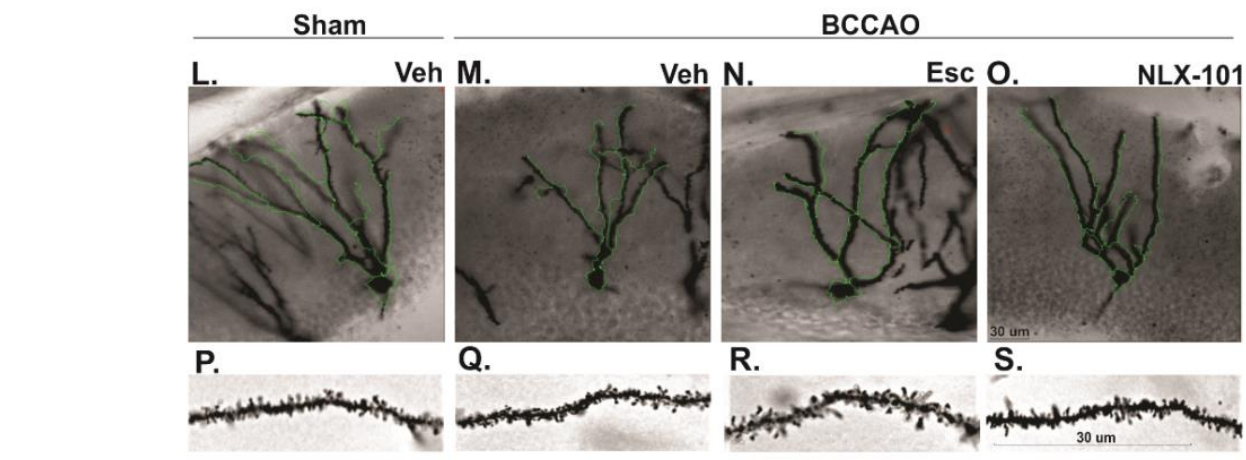

BCCAO
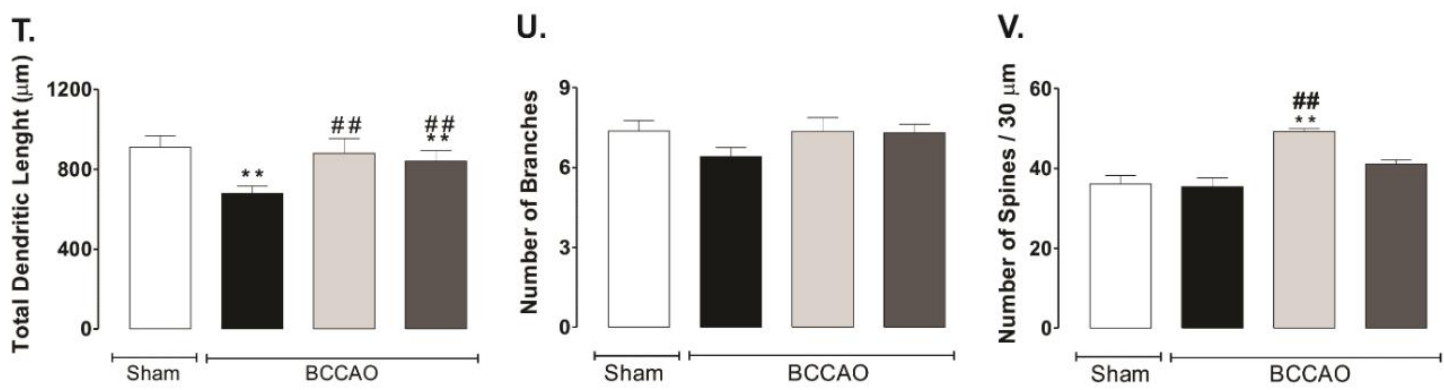

Figure 8: Esc and NLX-101 changes the dendritic remodeling in the prefrontal cortex (PFC) and dentate gyrus (DG) in the hippocampus in BCCAO mice. (A-H) 
Representative photomicrographies of pyramidal neurons and dendritic spines in the PFC (20 and 100x magnification). (I) Total length of dendritic tree, (J) number of branches and $(\mathrm{K})$ number of dendritic spines in $30 \mu \mathrm{m}$-secondary branches of pyramidal neurons in the PFC. (L-S) Representative photomicrographies of granular neurons and dendritic spines in the DG of hippocampus (20 and 100x - magnification). (T) Total length of dendritic tree, (U) number of branches and (V) number of dendritic spines in $30 \mu \mathrm{m}$ secondary branches of granular neurons in the DG. Bars represent mean \pm S.E.M of the different groups ( $\mathrm{n}=7$ /group). ${ }^{*} p<0.05$ vs. Sham + Veh; ${ }^{\#} p<0.05,{ }^{\#} p<0.01$ vs. BCCAO + Veh group.

In the hippocampus, there were significant differences regarding the total dentritic length $\left(\chi^{2}=278.05 ; p<0.01\right.$; Fig. 5T) and number of spines $\left(\chi^{2}=22.2 ; p<0.01 ;\right.$ Fig. 5V) in the granular neurons. BCCAO + Veh group showed a decrease in the total dentritic length as compared to Sham + Veh group $(p<0.01)$. Esc or NLX-101 prevented the effects of BCCAO in the total dendritic length $(p<0.01)$. Esc also induced an increase in the number of spines in BCCAO mice when compared to controls $(p<0.01)$.

No significant differences were observed among the experimental groups concerning the number of branches in the PCF $\left(\chi^{2}=2.37 ; p=0.49\right.$; Fig. $\left.5 \mathrm{~J}\right)$ or hippocampus ( $\chi^{2}=0.66 ; p=0.88$; Fig. $\left.5 U\right)$.

EsC and NLX-101 effects on neurodegeneration and synaptic plasticity in BCCAO animals.

In the PFC, Western blot analysis revelead differences in the protein levels of PSD$95\left(\chi^{2}=33.19, p<0.01\right.$; Fig. $\left.6 \mathrm{D}\right)$ while no differences were detected in the levels of NeuN and SYN ( $\chi^{2}=3.23-3.47 ; p>0.05$; Fig. $6 \mathrm{~B}$ and $\mathrm{C}$, respectively) among the experimental groups. BCCAO mice presented a decrease in the levels of PSD-95 protein when compared to Sham animals $(p<0.01)$, an effect that was attenuated by Esc treatment ( $p$ $<0.05$ vs. vehicle).

In the hippocampus, a main effect of groups for the levels of $\mathrm{NeuN}\left(\chi^{2}=13.33 ; p\right.$ $<0.01$; Fig. 6F), SYN ( $\chi^{2}=15.09 ; p<0.01$; Fig. $\left.6 \mathrm{G}\right)$ and PSD-95 $\left(\chi^{2}=17.24 ; p<0.01\right.$; Fig. $6 \mathrm{H}$ ). Compared to sham-operation, BCCAO induced a decrease in the NeuN ( $p<$ $0.01)$, SYN $(p<0.05)$ and PSD-95 $(p<0.01)$ protein levels. Both Esc and NLX-101 treatment resulted in an increase in the hippocampal SYN (Esc, $p<0.01$ and NLX-101, 
$p<0.05$ ) and PSD-95 (Esc, $p<0.05$ and NLX-101 $p<0.01$ ) protein levels when compared to ischemic animals that received Veh.

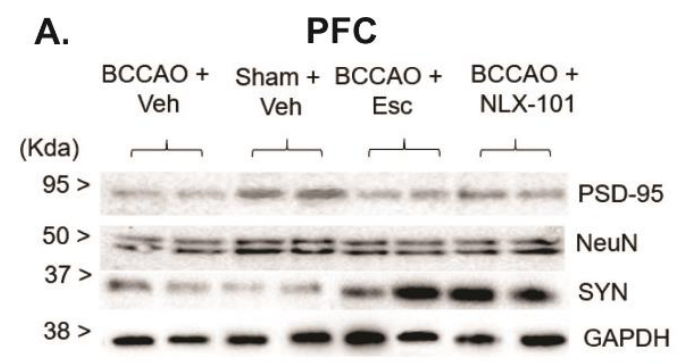

B.

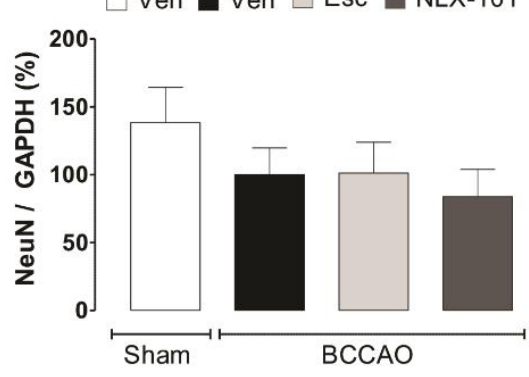

C.

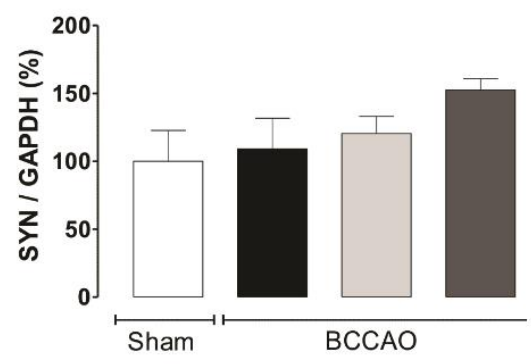

D.

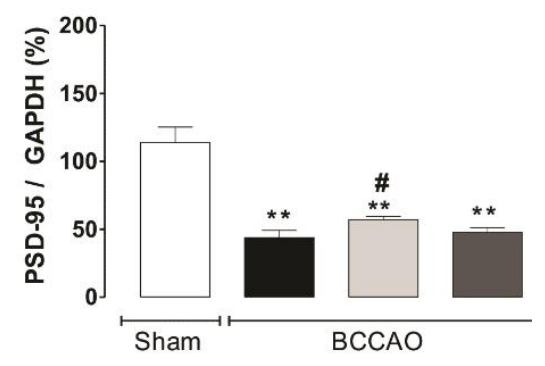

E. Hippocampus

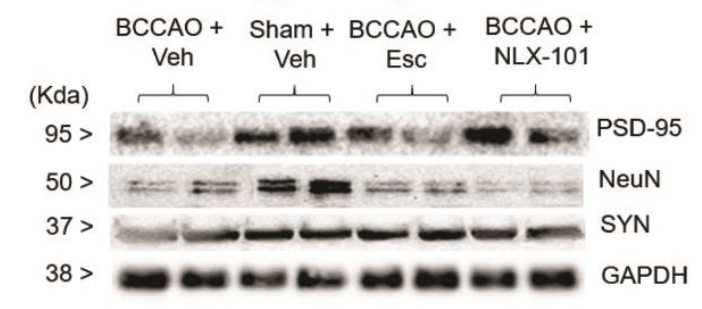

F.

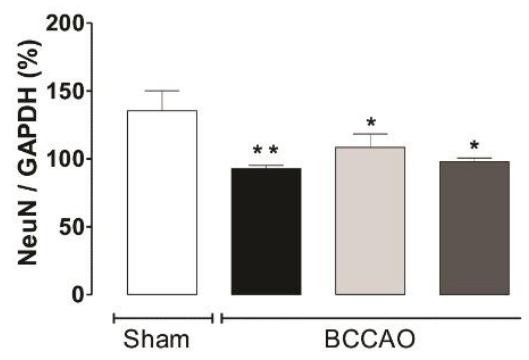

G.

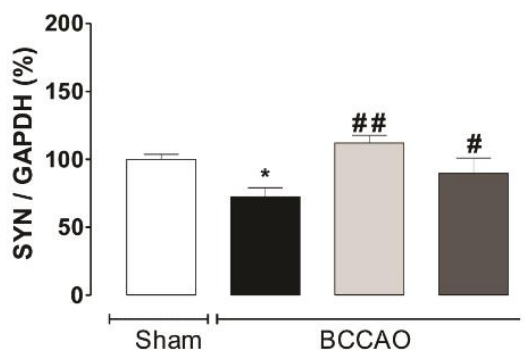

H.

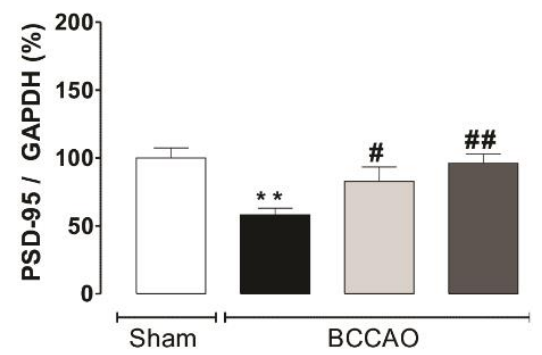

Figure 9: Esc and NLX-101 effects on neurodegeneration and synaptic plasticity in the prefrontal cortex (PFC) and hippocampus in BCCAO animals. Representative blots of neuronal nuclei (NeuN), synaptophysin (SYN) and postsynaptic density protein95 (PSD-95) proteins in the (A) PFC and (E) hippocampus. Protein levels of NeuN, SYN and PSD-95 in the (B-D) PFC and (F-H) hippocampus. Bars represent mean \pm S.E.M of 
the different groups ( $n=5-6 /$ group). ${ }^{*} p<0.05$ vs. Sham + Veh; ${ }^{\#} p<0.05,{ }^{\#} p<0.01$ vs. $\mathrm{BCCAO}+$ Veh.

\section{Discussion}

In the present study, we found that BCCAO induced anxiety-like behavior, impaired hippocampus-dependent cognitive function, and increased despair-like behavior in mice. Decreases in the protein levels of NeuN, BDNF, SYN, and PSD-95 were detected mainly in the hippocampus or some of that in the PFC in ischemic mice. Moreover, BCCAO provoked damage in dendritic structures in those vulnerable brain regions. The biased 5-HT1A receptor agonist NLX-101 (a.k.a. F15559), attenuated cognitive impairments and despair-like behaviors that were induced by brain ischemia. In addition to its behavioral effects, NLX-101 restored the levels of SYN and PSD-95 in the hippocampus of ischemic mice. In general, NLX-101 and Esc increased the BDNF protein levels and impacted neuronal morphology in both hippocampus and PFC of BCCAO mice. Esc decreased anxiety-like behaviors and attenuated the reduction of PSD-95 protein levels in the PFC of BCCAO mice. As NLX-101 was not effective on these measures, this suggests that PFC postsynaptic $5-\mathrm{HT}_{1 \mathrm{~A}}$ receptoprs are likely not fully involved in mediating these effects of Esc. Both NLX-101 and Esc blocked the increase in basal plasma corticosterone levels that was induced by BCCAO. The present results indicate that NLX-101 might also counteract functional and neurodegenerative outcomes of brain ischemia in mice.

5- $\mathrm{HT}_{1 \mathrm{~A}}$ receptor agonists may elicit differential and sometimes opposing responses in rodents. In behavioral tests, for example, anxiolytic-like effects have been related to $5-\mathrm{HT}_{1 \mathrm{~A}}$ autoreceptor activation, whereas antidepressant-like activity has been shown to be mediated by the activation of $5-\mathrm{HT}_{1 \mathrm{~A}}$ postsynaptic receptors (Celada el al., 2013; Garcia-Garcia et al., 2014 Depoortère et al., 2019). These different responses occur because $5-\mathrm{HT}_{1 \mathrm{~A}}$ agonists generally indiscriminately activate $5-\mathrm{HT}_{1 \mathrm{~A}}$ receptors in different brain regions and different signaling pathways (Newman-Tancredi et al., 2011). In the present study, we compared the effects of two compounds, NLX-101 (a biased agonist that preferentially activates postsynaptic $5-\mathrm{HT}_{1 \mathrm{~A}}$ receptors) and Esc (a SSRI that blocks the serotonin transporter), resulting in indistinct increases in extracellular 5-HT levels in the brain. With regard to functional recovery after brain ischemia, Esc improved 
cognitive performance in the OLT and prevented the expression of anxiety- and despairlike behavior in ischemic animals. NLX-101 improved memory performance and prevented behavioral dispair. These data are in accordance with previous studies showing that NLX-101 exerts antidepressant-like and pro-cognitive effects in rodents (Depoortère et al., 2010; Newman-Tancredi et al., 2011; Van Goethem et al., 2015). Of note, NLX-101 has been shown to have positive effects in a pattern separation task implicated in episodic memory (Van Goethem et al., 2015) and to alleviate the detrimental effects of phencyclidine on memory in rats in the hole-board test when acutely injected (Depoortère et al., 2010). Importanly, the acute effects of NLX-101 on cognition was not shared by the non-biased 5-HT1 A agonist 8-OHDPAT, or by the preferential presynaptic 5- $\mathrm{HT}_{1 \mathrm{~A}}$ receptor agonist, $\mathrm{F} 13714$ (Depoortère et al., 2010).

Brain ischemia is followed by an increase in corticosterone secretion, which may exacerbate brain damage. Several studies have shown that preventing the rise in basal corticosterone levels that is induced by brain ischemia can increase cell survival and preserve synaptic function (Sapolsky and Pulsinelli, 1985; Morse and Davis, 1990; Krugers et al., 1998; Krugers et al., 2000). We observed a decrease in blood corticosterone levels with Esc and NLX-101 treatments in BCCAO mice. These results indicate that repeated treatment with both Esc and NLX-101 may modulate hypothalamicpituitary-adrenal axis function in mice with brain ischemia.

In the present study, we observed a decrease in BDNF levels in the PFC and hippocampus in BCCAO mice. Treatment with Esc increased BDNF levels in the hippocampus in BCCAO mice. These results are consistent with previous studies that showed that SSRIs, such as fluoxetine (Kim et al., 2007) and Esc (Lee et al., 2011), increased BDNF immunoreactivity and protein levels in the hippocampus in gerbils that were subjected to transient global brain ischemia. Additionally, Espinera et al. (2013) found that citalopram increased the expression of BDNF in the peri-infarct region in mice with focal brain ischemia. In the present study, repeated treatment with NLX-101 restored BDNF levels in the PFC and hippocampus in BCCAO mice to sham levels. To our knowledge, no previous study assessed the effects of NLX-101 on BDNF expression in the ischemic brain. BDNF is a neurotrophic factor that plays an important role in regulating the survival of neurons, neurogenesis, and neuroplasticity (Begni et al., 2017). 
Favorable effects of BDNF on functional recovery and neuroplasticity after brain ischemia have been reported (Schäbitz et al., 2007; Espinera et al., 2013; Soares et al., 2016). The present results suggest that the effect of NLX-101 on BDNF levels may be associated with neuroprotective effects after ischemic insult.

The hippocampus and PFC play a central role in spatial learning and memory, which have been closely related to the plasticity of dendritic arborization and morphological changes such as expansion and contraction (Knafo et al., 2004; Frankfurt and Luine, 2015; Milner and Klein, 2016). Dendritic spines are an active site of neuroplasticity, including synaptogenesis and synaptic remodeling (Spruston, 2008). Brain ischemia has a profound effect on the structure and function of synapses that is associated with impairments in neurological function (Hasbani et al., 2000). The loss of hippocampal neurons and synapses following brain ischemia have been related to cognitive impairments, including poor spatial memory performance (He et al., 2012). Notably, these neuroplastic responses can be stimulated by pharmacological interventions. For example, a single intravenous injection of melatonin mitigated the loss of dendritic spines of pyramidal neurons in the PFC and hippocampus that survived for up to 120 days after transient global brain ischemia (González-Burgos et al., 2007; García-Chávez et al., 2008). Similar recovery of dendritic spines was conferred by treatment with progesterone and allopregnanolone (Moralí et al., 2012), which also alleviated learning and memory deficits that were caused by ischemia (Moralí et al., 2011). Ischemia-induced dendritic spine deterioration in the hippocampus was prevented by acetyl-L-carnitine administration before and after ischemia, an effect that paralleled the normalization of hippocampal long-term potentiation, indicating the improvement of synaptic function at dendritic spines (Kocsis et al., 2014). In the present study, BCCAO mice exhibited significant dendritic spine loss in cortical neurons but not in hippocampal neurons that survived up to 21 days of brain ischemia. The reason for this regional difference in the effects of BCCAO on dendritic spine density is unknown but may be related to the duration and degree of neuronal vulnerability to damage after brain ischemia (Zhu et al., 2017). Both Esc and NLX-101 increased the levels of BDNF in the hippocampus and PFC (except for Esc) in ischemic mice. The ability of NLX-101 to increase BDNF levels and restore dendritic remodeling in the hippocampus provides 
preliminary evidence that it can play a role in regulating synaptic plasticity in mice with brain ischemia.

The stimulation of endogenous mechanisms that are related to plasticity may confer functional recovery and neuroprotection after brain ischemia (Chen et al., 2005; Cui et al., 2013; Ishrat et al., 2015). Both SYN and PSD-95 are the main proteins that participate in structural synaptic plasticity (Sadigh-Eteghad et al., 2018). SYN is a marker of pre-synapse development and activity (Yong et al., 2014), and PSD-95 is an essential factor for synaptic plasticity and postsynaptic membrane stabilization (Luo et al., 2013). The expression of SYN and PSD-95 markedly decreases in the hippocampus after experimental brain ischemia (Ishimaru et al., 2001; Zhao et al., 2011; Yan et al., 2013). In the present study, likewise PSD-95 levels decreased in the PFC and hippocampus after BCCAO. A decrease in the levels of SYN was observed in the hippocampus in BCCAO mice, which was restored by Esc or NLX-101 treatment. The relevance of these

findings is underscored by the fact that PSD-95 regulates the strength of excitatory neurotransmission (Blanpied et al., 2008), and the recovery of PSD-95 levels may determine the degree of functional recovery after an ischemic insult. Furthermore, in the hippocampus this recovery is related to postsynaptic $5-\mathrm{HT}_{1 \mathrm{~A}}$ receptor, while these receptors appear to play a minor role in the PFC in this respect.

\section{Conclusion}

In summary, the protective effects of Esc and NLX-101 on cortical and hippocampal neurons paralleled with their restorative or stimulating effect on the expression of BDNF, SYN and PSD-95, suggesting a relationship between these proteins, dendritic remodeling, and functional recovery after BCCAO. Moreover, the overall similarity in the effects of Esc and NLX-101 suggests that the protective effects of SSRIs in BCCAO are mediated specifically by activation of post-synaptic $5-\mathrm{HT}_{1 \mathrm{~A}}$ receptors, especially in the hippocampus. Direct targeting of this receptor subpopulation with biased agonists such as NLX-101 may constitute a new strategy for therapeutic intervention in brain ischemia patients.

\section{Acknowledgements}


The authors gratefully acknowledge the financial support by the Coordenação de Aperfeiçoamento de Pessoal de Nível Superior (CAPES, Program CAPES/NUFFIC 8888.7156.527/2017-00) for providing Rafael Pazinatto Aguiar fellowship and The State University of Maringá (UEM) for providing the animals. We also thank Marcos A. Trombelli for helping with the overall animal care and Hellen Steinbusch for helping with the morphological evaluations in the Golgi-cox assay.

\section{Conflict of Interest}

Adrian Newman-Tancredi and Mark Varney are employees and stockholders of Neurolixis. 


\section{References}

Acler M, Robol E, Fiaschi A, Manganotti P. 2009. A double blind placebo RCT to investigate the effects of serotonergic modulation on brain excitability and motor recovery in stroke patients. J. Neurol. 256(7), 1152-1158.

Albert PR, Vahid-Ansari, F. 2019. The 5-HT1A receptor: Signaling to behavior. Biochimie. 161, 34-45.

Arvidsson LE., Hacksell U, Nilsson JL, Hjorth S, Carlsson A, Lindberg P, Sanchez, D, Wikstrom H. 1981. 8-Hydroxy-2-(di-n-propylamino)tetralin, a new centrally acting 5-hydroxytryptamine receptor agonist. J Med Chem 24(8), 921-923.

Assié MB, Ravailhe V, Faucillon V, Newman-Tancredi A. 2005. Contrasting contribution of 5-hydroxytryptamine $1 \mathrm{~A}$ receptor activation to neurochemical profile of novel antipsychotics: frontocortical dopamine and hippocampal serotonin release in rat brain. J Pharmacol Exp Ther. 315(1), 265-272.

Assié MB, Bardin L, Auclair AL, Carilla-Durand E, Depoortère R, Koek W, Kleven, MS, Colpaert F, Vacher B, Newman-Tancredi A. 2010. F15599, a highly selective postsynaptic $5-\mathrm{HT}(1 \mathrm{~A})$ receptor agonist: in-vivo profile in behavioural models of antidepressant and serotonergic activity. Int $J$ Neuropsychopharmacol. 13(10), 1285-1298.

Ayerbe L, Ayis S, Wolfe CD, Rudd AG. 2013. Natural history, predictors and outcomes of depression after stroke: systematic review and meta-analysis. $\mathrm{Br} \mathrm{J}$ Psychiatry. 202(1), 14-21.

Begni V, Riva MA, Cattaneo A. 2017. Cellular and molecular mechanisms of the brainderived neurotrophic factor in physiological and pathological conditions. Clin Sci (Lond). 131(2), 123-138.

Blanpied TA, Kerr JM, Ehlers MD. 2008. Structural plasticity with preserved topology in the postsynaptic protein network. Proc Natl Acad Sci USA. 105(34), 12587-12592.

Bode-Greuel KM, Klisch J, Horváth E, Glaser T, Traber J. 1990. Effects of 5hydroxytryptamine1A-receptor agonists on hippocampal damage after transient forebrain ischemia in the Mongolian gerbil. Stroke. 21(12), 164-166.

Brown CE, Li P, Boyd JD, Delaney KR, Murphy TH. 2007. Extensive turnover of dendritic spines and vascular remodeling in cortical tissues recovering from stroke. $J$ Neurosci. 27(15), 4101-4109.

Burns TC, Verfaillie CM, Low WC. 2009. Stem cells for ischemic brain injury: a critical review. J Comp Neurol 515(1), 125-144.

Campos AC, Ortega Z, Palazuelos J, Fogaça MV, Aguiar DC, Díaz-Alonso J, OrtegaGutiérrez S, Vázquez-Villa H, Moreira FA, Guzmán M, Galve-Roperh I, Guimarães FS. 2013. The anxiolytic effect of cannabidiol on chronically stressed mice depends on hippocampal neurogenesis: involvement of the endocannabinoid system. The Int J Neuropsychopharmacol. 16(6), 1407-1419.

Can A, Dao, DT, Arad M, Terrillion CE, Piantadosi SC, Gould TD. 2012. The mouse forced swim test. J Vis Exp 59, e3638.

Carmichael ST. 2011. Brain excitability in stroke: the yin and yang of stroke progression. Arch Neurol 69(2), 161-167.

Celada P, Bortolozzi A, Artigas F. 2013. Serotonin 5-HT1A receptors as targets for agents to treat psychiatric disorders: rationale and current status of research. CNS Drugs. 
27(9), 703-716.

Chalmers DT, Watson SJ. 1991. Comparative anatomical distribution of 5-HT1A receptor mRNA and 5-HT1A binding in rat brain - a combined in situ hybridisation/in vitro receptor autoradiographic study. Brain Res. 561(1), 51-60.

Chen J, Zhang C, Jiang H, Li Y, Zhang L, Robin A. Katakowski, M., Lu, M., Chopp, M., 2005. Atorvastatin induction of VEGF and BDNF promotes brain plasticity after stroke in mice. J Cereb Blood Flow Metab. 25(2), 281-290.

Chilmonczyk Z, Bojarski AJ, Pilc A, Sylte I. 2017. Serotonin transporter and receptor ligands with antidepressant activity as neuroprotective and proapoptotic agents. Pharmacol Rep. 69(3), 469-478.

Chollet F, Tardy J, Albucher JF, Thalamas C, Berard E, Lamy C, Bejot Y, Deltour S, Jaillard A, Niclot P, Guillon B, Moulin T, Marque P, Pariente J, Arnaud C, Loubinoux I. 2011. Fluoxetine for motor recovery after acute ischaemic stroke (FLAME): a randomised placebo-controlled trial. Lancet Neurol. 10(2), 123-130.

Cryan JF, Kelliher P, Kelly JP, Leonard BE. 1999. Comparative effects of serotonergic agonists with varying efficacy at the $5-\mathrm{HT}(1 \mathrm{~A})$ receptor on core body temperature: modification by the selective $5-\mathrm{HT}(1 \mathrm{~A})$ receptor antagonist WAY 100635. J Psychopharmacol. 13(3), 278-283.

Cui DR, Wang L, Jiang W, Qi AH, Zhou QH, Zhang XL. 2013. Propofol prevents cerebral ischemia-triggered autophagy activation and cell death in the rat hippocampus through the NF-KB/p53 signaling pathway. Neuroscience. 246, 117-132.

Dam M, Tonin P, De Boni A, Pizzolato G, Casson S, Ermani M, Freo U, Piron L, Battistin L. 1996. Effects of fluoxetine and maprotiline on functional recovery in poststroke hemiplegic patients undergoing rehabilitation therapy. Stroke. 27(7), 1211-1214.

Denninger JK, Smith BM, Kirby ED. 2018. Novel object recognition and object location behavioral testing in mice on a budget. J Vis Exp. (141):10.3791/58593

Depoortère R, Auclair AL, Bardin L, Colpaert FC, Vacher B, Newman-Tancredi A. 2010. F15599, a preferential post-synaptic 5-HT1A receptor agonist: activity in models of cognition in comparison with reference 5-HT1A receptor agonists. Eur. Neuropsychopharmacol. 20(9), 641-654.

Depoortère R, Bardin L, Varney MA, Newman-Tancredi A. 2019. Serotonin 5-HT1A receptor biased agonists display differential anxiolytic activity in a rat social interaction model. ACS Chem Neurosci. 10(7), 3101-3107.

Dhami KS, Churchward MA, Baker GB, Todd KG. 2013. Fluoxetine and citalopram decrease microglial release of glutamate and $D$-serine to promote cortical neuronal viability following ischemic insult. Mol Cell Neurosci 56, 365-374.

Espinera AR, Ogle ME, Gu X, Wei L. 2013. Citalopram enhances neurovascular regeneration and sensorimotor functional recovery after ischemic stroke in mice. Neuroscience. 247, 1-11.

Fogaça MV, Campos AC, Coelho LD, Duman RS, Guimarães FS. 2018. The anxiolytic effects of cannabidiol in chronically stressed mice are mediated by the endocannabinoid system: role of neurogenesis and dendritic remodeling. Neuropharmacology. 135:22-33.

Frankfurt M, Luine V. 2015. The evolving role of dendritic spines and memory: Interaction(s) with estradiol. Horm Behav. 74, 28-36.

García-Chávez D, González-Burgos I, Letechipía-Vallejo G, López-Loeza E, Moralí G, 
Cervantes M. 2008. Long-term evaluation of cytoarchitectonic characteristics of prefrontal cortex pyramidal neurons, following global cerebral ischemia and neuroprotective melatonin treatment, in rats. Neurosci Lett. 448(1), 148-152.

Garcia-Garcia AL, Newman-Tancredi A, Leonardo ED. 2014. P5-HT1A receptors in mood and anxiety: recent insights into autoreceptor versus heteroreceptor function. Psychopharmacology. 231(4), 623-636.

Gellért L, Varga D. 2016. Locomotion activity measurement in an open field for mice. Bioprotocol. 6(13), e1857.

González-Burgos I, Letechipía-Vallejo G, López-Loeza E, Moralí G, Cervantes, M. 2007. Long-term study of dendritic spines from hippocampal CA1 pyramidal cells, after neuroprotective melatonin treatment following global cerebral ischemia in rats. Neurosci Lett. 423(2), 162-166.

Gould E, Woolley CS, Frankfurt M, McEwen BS. 1990. Gonadal steroids regulate dendritic spine density in hippocampal pyramidal cells in adulthood. J Neurosci. 10(4), 1286-1291.

Hasbani MJ, Underhill SM, De Erausquin G, Goldberg MP. 2000. Synapse loss and regeneration: a mechanism for functional decline and recovery after cerebral ischemia? Neuroscientist. 6(2), 110-119.

He H, Mahnke AH, Doyle S, Fan N, Wang CC, Hall BJ, Tang YP, Inglis FM, Chen C, Erickson JD. 2012. neurodevelopmental role for vglut2 in pyramidal neuron plasticity, dendritic refinement, and in spatial learning. J Neurosci. 32(45), 1588615901.

Hind WH, England TJ, O'Sullivan SE. 2016. Cannabidiol protects an in vitro model of the blood-brain barrier from oxygen-glucose deprivation via PPARY and 5-HT1A receptors. Br J Pharmacol, 173(5), 815-825.

Ishimaru H, Casamenti F, Uéda K, Maruyama Y, Pepeu G. 2001. Changes in presynaptic proteins, SNAP-25 and synaptophysin, in the hippocampal CA1 area in ischemic gerbils. Brain Res 903(1-2), 94-101.

Ishrat T, Pillai B, Soliman S, Fouda AY, Kozak A, Johnson MH, Ergul A, Fagan, SC, 2015. Low-dose candesartan enhances molecular mediators of neuroplasticity and subsequent functional recovery after ischemic stroke in rats. Mol Neurobiol. 51(3), $1542-1453$.

Johansen FF, Hasseldam H, Nybro Smith M, Rasmussen RS. 2014. Drug-induced hypothermia by $5 \mathrm{HT} 1 \mathrm{~A}$ agonists provide neuroprotection in experimental stroke: new perspectives for acute patient treatment. J Stroke Cerebrovasc Dis. 23(10), $2879-2887$.

Jorge RE, Acion L, Moser D, Adams HPJ, Robinson RG. 2010. Escitalopram and enhancement of cognitive recovery following stroke. Arch Gen Psychiatry. 67(2), 187-196.

Khodanovich MY, Kisel AA. 2015. Animal models of cerebral ischemia. AIP Conf Proc. 1688, 030037-1-030037-8.

Kim DH, Li H, Yoo KY, Lee BH, Hwang IK, Won MH. 2007. Effects of fluoxetine on ischemic cells and expressions in BDNF and some antioxidants in the gerbil hippocampal CA1 region induced by transient ischemia. Exp Neurol. 204(2), 748758.

Klisch J, Bode-Greuel KM, Horvath E, Klisch C, Els T. 2003. Additive neuroprotective 
effect of Ketanserin and Ipsapirone on the hippocampal damage after transient forebrain ischemia in the Mongolian gerbil. Neurosci Lett 342(1-2), 25-28.

Knafo S, Ariav G, Barkai E, Libersat F. 2004. Olfactory learning-induced increase in spine density along the apical dendrites of CA1 hippocampal neurons. Hippocampus. 14(7), 819-825.

Kocsis K, Knapp L, Gellért L, Oláh G, Kis Z, Takakuwa H, Iwamori N, Ono E, Toldi J, Farkas T. 2014. Acetyl-L-carnitine normalizes the impaired long-term potentiation and spine density in a rat model of global ischemia. Neuroscience. 269, 265-272.

Koek W, Patoiseau JF, Assié MB, Cosi C, Kleven MS, Dupont-Passelaigue E, CarillaDurand E, Palmier C, Valentin JP, John, G, Pauwels PJ, Tarayre JP, Colpaert, FC. 1998. F 11440, a potent, selective, high efficacy 5-HT1A receptor agonist with marked anxiolytic and antidepressant potential. J Pharmacol Exp Ther 287(1), 266-283.

Koek W, Vacher B, Cosi C, Assié MB, Patoiseau JF, Pauwels PJ, Colpaert FC, 2001. 5HT1A receptor activation and antidepressant-like effects: $F 13714$ has high efficacy and marked antidepressant potential. Eur J Pharmacol. 420(2-3), 103112.

Krugers, H.J., Kemper, R.H., Korf, J., Ter Horst, G.J, Knollema, S., 1998. Metyrapone reduces rat brain damage and seizures after hypoxia-ischemia: an effect independent of modulation of plasma corticosterone levels? J Cereb Blood Flow Metab. 18(4), 386-390.

Krugers HJ, Maslam S, Korf J, Joëls M, Holsboer F. 2000. The corticosterone synthesis inhibitor metyrapone prevents hypoxia/ischemia-induced loss of synaptic function in the rat hippocampus. Stroke. 31(5), 1162-1172.

Kulkarni SK, Singh K, Bishnoi M, 2007. Elevated zero maze: a paradigm to evaluate antianxiety effects of drugs. Methods. Find Exp Clin Pharmacol. 29(5), 343-348.

Lee CH, Park JH, Yoo KY, Choi JH, Hwang IK, Ryu PD, Kim DH, Kwon YG, Kim YM, Won $\mathrm{MH}$. 2011. Pre- and post-treatments with escitalopram protect against experimental ischemic neuronal damage via regulation of BDNF expression and oxidative stress. Exp Neurol. 229(2), 450-459.

Lim CM, Kim SW, Park JY, Kim C, Yoon SH, Lee JK. 2009. Fluoxetine affords robust neuroprotection in the postischemic brain via its anti-inflammatory effect. $J$. Neurosci Res. 87(4), 1037-1045.

Luo J, Zhang L, Ning N, Jiang H, Yu SY. 2013. Neotrofin reverses the effects of chronic unpredictable mild stress on behavior via regulating BDNF, PSD-95 and synaptophysin expression in rat. Behav Brain Res. 253, 48-53.

Marco I, Valhondo M, Martín-Fontecha M, Vázquez-Villa H, Del Río J, Planas A, Sagredo O, Ramos JA, Torrecillas IR, Pardo L, Frechilla D, Benhamú B, López-Rodríguez ML. 2011. New serotonin $5-H T(1 \mathrm{~A})$ receptor agonists with neuroprotective effect against ischemic cell damage. J Med Chem 54(23), 7986-7999.

Mead GE, Hsieh CF, Lee R, Kutlubaev M, Claxton A, Hankey GJ, Hackett M, 2013. Selective serotonin reuptake inhibitors for stroke recovery: a systematic review and meta-analysis. Stroke. 44(3), 844-850.

Milner B, Klein D. 2016. Loss of recent memory after bilateral hippocampal lesions: memory and memories-looking back and looking forward. J Neurol Neurosurg Psychiatry. 87(3):230. 
Meijering E. 2010. Neuron tracing in perspective. Cytometry A. 77(7), 693-704.

Moralí G, Montes P, Hernández-Morales L, Monfil T, Espinosa-García C, Cervantes M. 2011. Neuroprotective effects of progesterone and allopregnanolone on long-term cognitive outcome after global cerebral ischemia. Restor Neurol Neurosci. 29(1), $1-15$.

Moralí G, Montes P, González-Burgos I, Velázquez-Zamora DA, Cervantes M, 2012. Cytoarchitectural characteristics of hippocampal CA1 pyramidal neurons of rats, four months after global cerebral ischemia and progesterone treatment. Restor Neurol Neurosci, 30(1), 1-8.

Morse JK, Davis JN. 1990. Regulation of ischemic hippocampal damage in the gerbil: Adrenalectomy alters the rate of CA1 cell disappearance. Exp Neurol. 110(1), 8692.

Moulaert VR, Wachelder EM, Verbunt JA, Wade DT, van Heugten CM. 2010. Determinants of quality of life in survivors of cardiac arrest. J Rehabil Med. 42(6), 553-558.

Newman-Tancredi A, Martel JC, Assié MB, Buritova J, Lauressergues E, Cosi C, Heusler P, Bruins Slot L, Colpaert FC, Vacher B, Cussac D. 2009. Signal transduction and functional selectivity of F15599, a preferential post-synaptic 5-HT1A receptor agonist. Br. J. Pharmacol. 156(2), 338-353.

Newman-Tancredi A. 2011. Biased agonism at serotonin 5-HT 1 A receptors: preferential postsynaptic activity for improved therapy of CNS disorders. Neuropsychiatry. 1(2), 149-164.

Pazos A, Cortés R, Palacios JM. 1985. Quantitative autoradiographic mapping of serotonin receptors in the rat brain. II. Serotonin-2 receptors. Brain. Res. 346(2), 231-249.

Pazos MR, Mohammed N, Lafuente H, Santos M, Martínez-Pinilla E, Moreno E, Valdizan E, Romero J, Pazos A, Franco R, Hillard CJ, Alvarez FJ, Martínez-Orgado J, 2013. Mechanisms of cannabidiol neuroprotection in hypoxic-ischemic newborn pigs: role of $5 \mathrm{HT}(1 \mathrm{~A})$ and CB2 receptors. Neuropharmacology. 71, 282-291.

Paxinos G, Franklin KBJ. 2001. The mouse brain: stereotaxic coordinates. 2nd Edition, Academic Press, San Diego.

Pyapali GK, Turner DA. 1994. Denervation-induced dendritic alterations in CA1 pyramidal cells following kainic acid hippocampal lesions in rats. Brain Res. 652(2), 279290.

Ramos AJ, Rubio MD, Defagot C, Hischberg L, Villar MJ, Brusco A. 2004. The 5HT1A receptor agonist, 8-OH-DPAT, protects neurons and reduces astroglial reaction after ischemic damage caused by cortical devascularization. Brain Res. 1030(2), 201-220.

Sadigh-Eteghad S, Geranmayeh MH, Majdi A, Salehpour F, Mahmoudi J, Farhoudi M. 2018. Intranasal cerebrolysin improves cognitive function and structural synaptic plasticity in photothrombotic mouse model of medial prefrontal cortex ischemia. Neuropeptides. 71, 61-69.

Sapolsky RM, Pulsinelli WA. 1985. Glucocorticoids potentiate ischemic injury to neurons: therapeutic implications. Science. 229(4720), 1397-1400.

Schäbitz WR, Steigleder T, Cooper-Kuhn CM, Schwab S, Sommer C, Schneider A, Kuhn 
HG. 2007. Intravenous brain-derived neurotrophic factor enhances poststroke sensorimotor recovery and stimulates neurogenesis. Stroke. 38(7), 2165-2172.

Schaper C, Zhu Y, Kouklei M, Culmsee C, Krieglstein J. 2000. Stimulation of 5-HT1A receptors reduces apoptosis after transient forebrain ischemia in the rat. Brain. Res. 883(1), 41-50.

Schmidt A, Minnerup J. 2016. Promoting recovery from ischemic stroke. Expert. Rev. Neurother. 16(2), 173-186.

Siepmann T, Kepplinger J, Zerna C, Schatz U, Penzlin Al, Pallesen LP, Illigens BM, Weidner K, Reichmann H, Puetz V, Bodechtel U, Barlinn K. 2015. The effects of pretreatment versus de novo treatment with selective serotonin reuptake inhibitors on short-term outcome after acute ischemic stroke. J Stroke Cerebrovasc Dis. 8, 1886-1892.

Soares LM, De Vry J, Steinbusch HWM, Milani H, Prickaerts J, Weffort de Oliveira RM. 2016. Rolipram improves cognition, reduces anxiety- and despair-like behaviors and impacts hippocampal neuroplasticity after transient global cerebral ischemia. Neuroscience. 326, 69-83.

Spijker S. 2011. Dissection of Rodent Brain Regions. In: Li K. (eds) Neuroproteomics. Neuromethods. vol 57, Humana Press, Totowa, NJ.

Spruston N, 2008. Pyramidal neurons: dendritic structure and synaptic integration. Nat Rev Neurosci 9(3), 206-221.

Sun M, Brady RD, Wright DK, Kim HA, Zhang SR, Sobey CG, Johnstone MR, O'Brien TJ, Semple BD, McDonald SJ, Shultz SR. 2017. Treatment with an interleukin-1 receptor antagonist mitigates neuroinflammation and brain damage after polytrauma. Brain Brain Behav Immun. 66, 359-371.

Sun Y, Jin K, Xie L, Childs J, Mao XO, Logvinova A, Greenberg DA. 2003. VEGF-induced neuroprotection, neurogenesis, and angiogenesis after focal cerebral ischemia. The J. Clin. Invest. 111(12), 1843-1851.

Sunami E, Usuda K, Nishiyama Y, Otori T, Katsura K, Katayama Y. 2012. A preliminary study of fluvoxamine maleate on depressive state and serum melatonin levels in patients after cerebral infarction. Intern Med. 51(10), 1187-1193.

Tanaka R, Yamashiro K, Mochizuki H, Cho N, Onodera M, Mizuno Y, Urabe T, 2004. Neurogenesis after transient global ischemia in the adult hippocampus visualized by improved retroviral vector. Stroke. 35(6), 1454-1459.

van Goethem NP, Schreiber R, Newman-Tancredi A, Varney M, Prickaerts J, 2015. Divergent effects of the "biased" 5-HT1A receptor agonists F15599 and F13714 in a novel object pattern separation task. Br J Pharmacol. 172(10), 2532-2543.

Xu Y, Li S, Vernon MM, Pan J, Chen L, Barish PA, Zhang Y, Acharya AP, Yu J, Govindarajan SS, Boykin E, Pan X, O'Donnell JM, Ogle WO. 2011. Curcumin prevents corticosterone-induced neurotoxicity and abnormalities of neuroplasticity via 5-HT receptor pathway. J Neurochem. 118(5), 784-795.

Yan BC, Park JH, Ahn JH, Lee JC, Won MH, Kang IJ. 2013. Postsynaptic density protein (PSD)-95 expression is markedly decreased in the hippocampal CA1 region after experimental ischemia-reperfusion injury. J Neurol Sci. 330(1-2), 111-116.

Yong Z, Yan L, Gao X, Gong Z, Su R. 2014. Effects of thienorphine on synaptic structure and synaptophysin expression in the rat nucleus accumbens. Neuroscience. 274, 53-58. 
Zhao Y, Wang J, Liu C, Jiang C, Zhao C, Zhu Z. 2011. Progesterone influences postischemic synaptogenesis in the CA1 region of the hippocampus in rats. Synapse. 65(9), 880-891.

Zhu Y, Zhang Q, Zhang W, Li N, Dai Y, Tu J, Yang F, Brann, DW, Wang R. 2017. Protective Effect of $17 \beta$-Estradiol Upon Hippocampal Spine Density and Cognitive Function in an Animal Model of Vascular Dementia. Sci Rep. 7(1), 42660.

Zittel S, Weiller C, Liepert J. 2008. Citalopram improves dexterity in chronic stroke patients. Neurorehabil Neural Repair. 22(3), 311-314. 


\section{CHAPTER 4}

NLX-101, A BIASED 5-HT1A RECEPTOR AGONIST, IMPROVES PATTERN SEPARATION AND STIMULATES NEUROPLASTICITY IN AGED RATS.

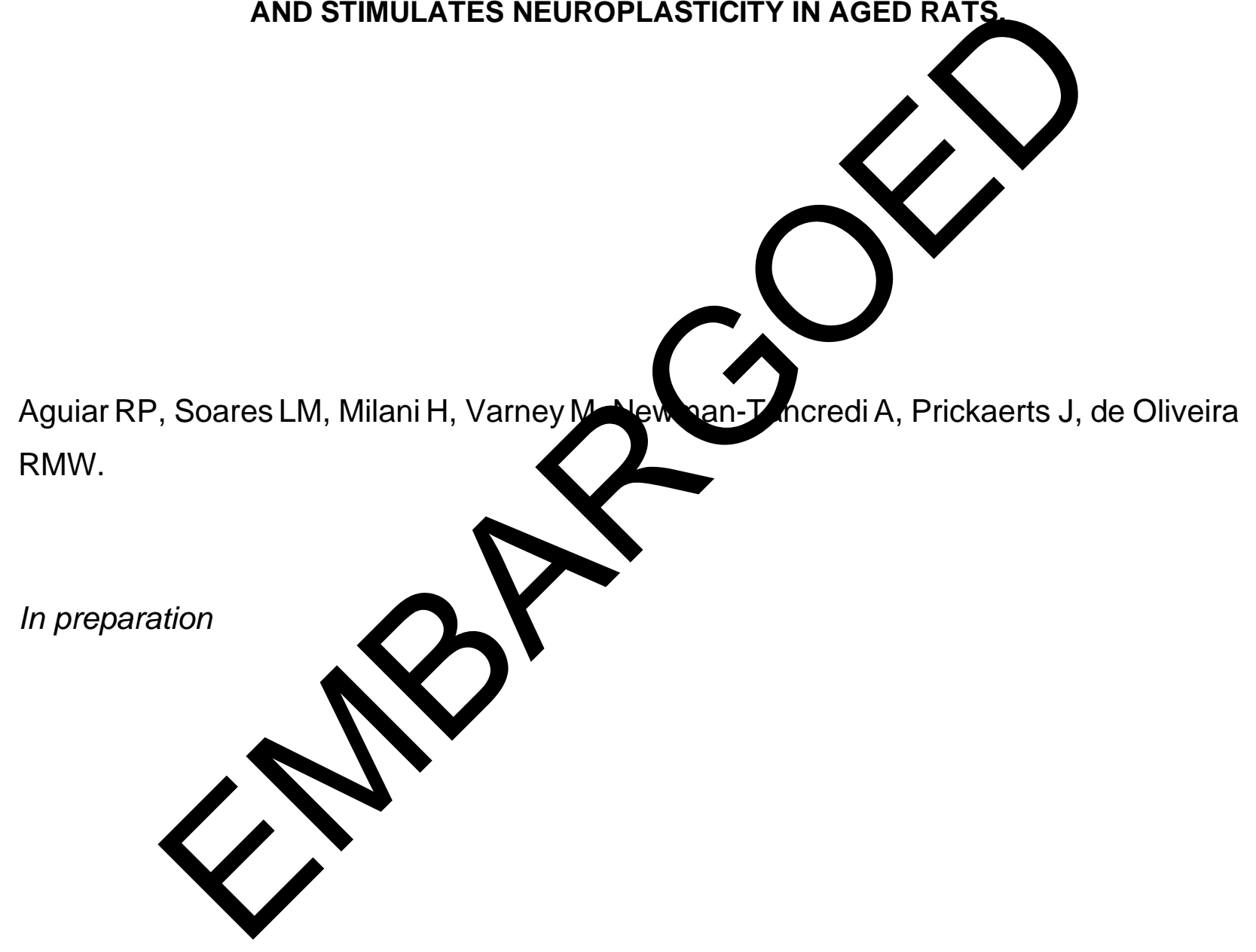




\section{CHAPTER 5}

INVOLVEMENT OF THE TYPE-1 CANNABINOID RECEPTOR (CB1) IN THE ANTISTRESS AND NEUROPLASTIC EFFECTS OF ANTIDEPRESSANTS

Aguiar RP, Ribeiro MA, Fusse EJ, Scarante FF, de Oliveira RMW, Guimarães FS, Campos AC.

In preparation 


\section{Abstract}

Several pieces of evidence suggest that the monoaminergic theory of depression cannot fully explain the behavioral and neuroplastic changes observed after antidepressant chronic treatment. Other molecular targets, such as the endocannabinoid system, have been associated with the chronic effects of these drugs. In the present study, we hypothesized that the behavioral and neuroplastic effects observed after repeated treatment with the antidepressants escitalopram (Esc) or venlafaxine (VFX) in chronically stressed mice depend on CB1 receptor activation. Male mice submitted to chronic unpredictable stress (CUS) paradigm for 21 days were treated with Esc $(10 \mathrm{mg} / \mathrm{Kg})$ or VFX $(20 \mathrm{mg} / \mathrm{kg})$ once a day in the presence or not of AM251 $(0,3 \mathrm{mg} / \mathrm{Kg})$, a CB1 receptor antagonist/inverse agonist. At the end of the CUS paradigm, we conducted behavior tests to evaluated depressive- and anxiety-like behaviors. Our results demonstrated that chronic blockade of the CB1 receptor by AM251 attenuated the antidepressant- but not the anxiolytic-like effects of Esc. AM251 decreased the pro-proliferative effects of Esc in the dentate gyrus. It also attenuated the increase in CB1 and PSD-95 expression in the hippocampus. AM251, however, failed to modify the antidepressant and anxiolytic effects of VFX. Our results suggest that CB1 receptors are not involved in the anxiolytic-like effects observed after repeated antidepressant treatment in animals submitted to CUS. However, CB1 receptors seem to participate in the antidepressant-like effects of selective serotonin reuptake inhibitors observed in this model. This anti-stress effect was associated with hippocampal neuroplastic changes.

Keywords: escitalopram; venlafaxine; CB1 receptor; stress; neuroplasticity; hippocampus. 


\section{Introduction}

A large body of research has suggested that stressful experiences play a crucial role in the development of psychiatric disorders such as anxiety and major depressive disorder (MDD) (Heim \& Nemeroff, 1999; Hammen, 2005; McEween, 1998; Maydaych, 2019). Antidepressants (ADs) such as selective serotonin reuptake inhibitors (SSRI) or the selective serotonin and noradrenaline reuptake inhibitors (SSNRI) are the first-line treatments for anxiety disorders, MDD, and other stress-related disorders. The clinical use of these drugs, however, is hindered by problems such as side-effects, late onset of therapeutic actions, incomplete remission of the symptoms, or even treatment-resistance (Cipriani et al., 2018).

Over the years, numerous groups have been trying to understand why ADs take weeks for the beginning of their therapeutic effects. Blier and colleagues suggested that the clinical improvement observed after chronic treatment with ADs depends on the desensitization of the type $1 \mathrm{~A}$ serotonergic receptors $\left(5-\mathrm{HT}_{1 \mathrm{~A}}\right)$ located in the soma of the neurons in raphe nuclei (Blier \& De Montigny, 1994; Blier, 2001). Other proposed hypotheses focused on ADs-induced neuroplastic changes involving hippocampal neurogenesis and dendritic remodeling (Santarelli et al., 2003; Bessa et al., 2009). Although these proposals are mostly based on the classical monoaminergic theory of depression, several pieces of evidence indicate that other neurotransmitter systems are involved. Among them, the endocannabinoid system could also be involved in the therapeutic effect of ADs (Hill et al., 2006a, 2006b; 2008; 2009).

The endocannabinoid system includes the $\mathrm{CB} 1$ and $\mathrm{CB} 2$ cannabinoid receptors, and the endocannabinoid ligands, anandamide (AEA) and 2-arachidonylglycerol (2AG) (Matsuda et al., 1990; Devane et al., 1992; Munro et al., 1993; Mechoulam et al., 1995). Endocannabinoids are classically defined as neuromodulators produced on demand from membrane phospholipids by specific enzymes widely expressed in the central nervous system (Thomas et al., 1997). Chronic antidepressant treatment positively modulates the expression of CB1 receptors and the levels of endocannabinoids ( $A E A$ and $2 A G$ ) in the hippocampus and prefrontal cortex (PFC), brain areas involved in the control of depressive states and anxiety disorders (Hill et al., 2006a, 2006b; 2008; 2009). Moreover, 
genetic manipulations of the endocannabinoid system impact serotonin function in the PFC and dorsal raphe nucleus (Bambico et al., 2009).

Serotonin and endocannabinoids play an important role in neuroplastic changes associated with depression such as dendritic remodeling and adult neurogenesis (Aguado et al., 2005; Jiang et al., 2005; Campos et al., 2013). However, the possible connection between chronic stress, ADs behavioral effects, neuroplasticity, and endocannabinoid systems is not yet been fully investigated (Fogaça et al., 2013).

In the present work, we tested the hypothesis that the endocannabinoid signaling, via the $\mathrm{CB} 1$ receptor, participates in the behavioral and neuroplastic effects caused by two antidepressants, escitalopram (Esc, a SSRI), and venlafaxine (VFX, a SNRI), in mice exposed to chronic unpredictable stress (CUS).

\section{Material and Methods}

\section{Animals}

Adult male C57BL6 (8-10 weeks old at the beginning of the protocols) derived from the colony of the Central Animal House of the University of São Paulo, Ribeirão Preto Campus (experiments conducted with Esc) and from the colony of the Multidisciplinary Center for Biological Investigation on Laboratory Animal Science- Campinas State University (experiments conducted with VFX) were used. Mice were allowed to acclimatize for at least two weeks in our animal facility before the beginning of the experiment. During the whole period (from their arrival until the end of the experiments), the animals were kept in a quiet room with controlled temperature and humidity $12: 12 \mathrm{~h}$ light/dark cycle (lights on at 6:30 am) and had free access to food and water (except for short periods during the stress protocols). Mice were randomly divided into stressed and non-stressed groups, housed in separate cages, and arbitrarily assigned to the pharmacological treatments. Each stress procedure as well as the behavioral tests were carried out in separate quiet rooms. The Ethical Committee of Animal Experimentation of the Ribeirão Preto Medical School (FMRP)- USP approved the experimental protocols according to the Brazilian laws and ARRIVE guide (CEUA/FMRP 032/2015-1, 01/2019).

\section{$\underline{\text { Drugs }}$}


The CB1 inverse agonist, AM251 (Tocris Bioscience, Bristol, UK), the SSRI, Esc and, the SSNRI VFX (Prati \& Donaduzzi Cia. Ltda, PR, Brazil) or vehicle [Veh, Tween $201 \%+$ DMSO $0.2 \%(v / v)]$ in saline $0.9 \%(w / v)$, were intraperitoneal (i.p) administered during 21 , between 4:00 p.m. and 5:00 p.m. The 5-Bromo-2-deoxyuridin (BrdU) (Sigma-Aldrich, Missouri, USA - $200 \mathrm{mg} / \mathrm{kg}$ in saline $0.9 \%$, w/v) was i.p administered one day before the sacrifice. The AM251 (0.3 mg/kg), VFX (20 mg/kg) and Esc (10 mg/kg) doses were based on previous studies (Campos et al., 2013; Seo et al., 2017). All solutions were freshly prepared and injected in a volume of $10 \mathrm{ml} / \mathrm{kg}$.

\section{Experimental Design}

Experiments I (Esc): the experiments were conducted as described in Figure 1. Independent groups of animals were submitted (or not) to the CUS paradigm for 21 days. During the CUS protocol, mice received i.p. injections of Veh or AM251 followed by Veh or Esc once a day with an interval of $30 \mathrm{~min}$ between each treatment. The injections were performed $6 \mathrm{~h}$ after the daily stressor. The following groups were generated: Veh + Veh (non-stressed); chronically stressed (CUS): Veh + Veh; Veh + Esc; AM251 + Veh; AM251 + Esc. On day $19^{\text {th }}, 15 \mathrm{~h}$ after the daily stressor and drug treatment, mice were exposed to the open field task (OF) (tests started at 8:00 a.m) to evaluate the locomotor activity. In the afternoon (test started at 1:00 p.m) of the same day, the animals were submitted to the tail suspension test (TST) to evaluate coping behaviors. On day $21^{\text {st }}$, the last day of daily stressors, the animals received a single i.p. injection of $\mathrm{BrdU}(200 \mathrm{mg} / \mathrm{kg})$ to evaluate cell proliferation in the dentate gyrus of the hippocampus. On day $22^{\text {nd }}, 24 \mathrm{~h}$ after the last drug administration, $20 \mathrm{~h}$ food-deprived mice were submitted to the novelty suppressed feeding (NSF) test to evaluate anxiety-like behavior. Brains were harvested immediately after the end of the last behavioral task for western blot, ELISA or immunohistochemistry/fluorescence assays.

Experiment II (VFX): the experimental design was similar to the experiments conducted with Esc. The following groups were generated: Veh + Veh (no stressed); chronically stressed (CUS): Veh + Veh; Veh + VFX; AM251 + Veh; AM251 + VFX. On day $19^{\text {th }}$ of the 
stress protocol, mice were submitted to the ST in the morning period. On day $22^{\text {nd }}$, about $24 \mathrm{~h}$ after the last drug treatment, the animals were submitted to the NSF test.

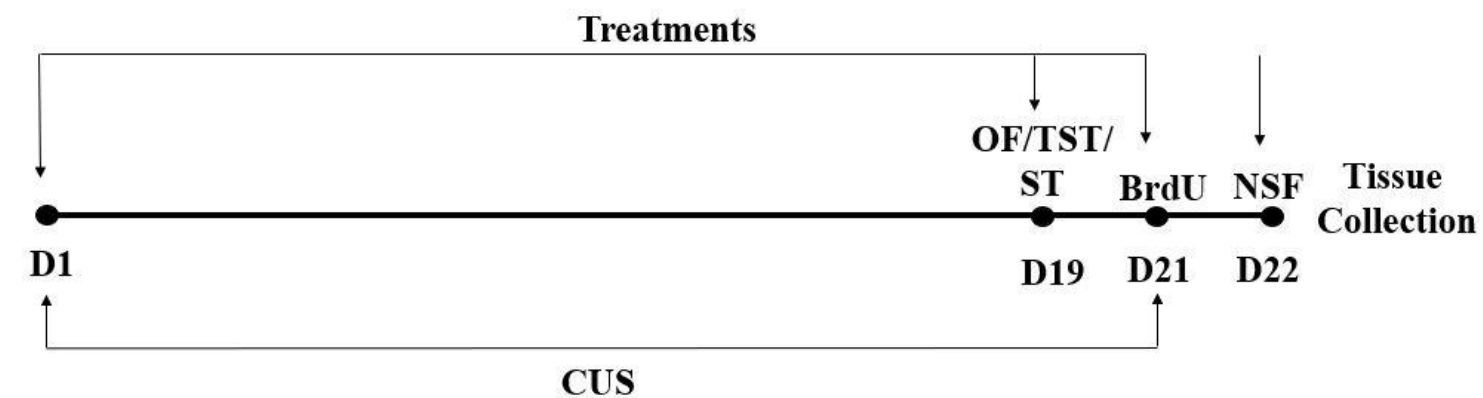

Figure 1. Timeline of the experimental designs used in experiments 1 and 2. D: day; OF open field; TST: tail suspension test; ST: splash test; NSF: novelty suppressed feeding.

\section{Protocols:}

\section{Chronic Unpredictable Stress}

During the light period of the cycle, mice were submitted to the CUS paradigm (Campos et al., 2013) for 21 consecutive days. Different daily mild stressors were randomly used: bedding alterations (sawdust removal, exposure to wet sawdust for $24 \mathrm{~h}$ ); food deprivation for $24 \mathrm{~h}$, the reversal of the light/dark cycle, forced swimming (15 min), inclined box overnight, restraint stress (2h). All efforts were made to minimize animal suffering during the procedures. We have carefully performed screenings of all animals for any injury or signal of disease.

\section{Open field (OF)}

The OF test is widely used to evaluate locomotion and exploratory behavior (Seibenhener and Wooten, 2015). The circular OF was made of transparent acrylic (50 $\mathrm{cm}$ high wall, and $40 \mathrm{~cm}$ of diameter). The floor was made of white acrylic. On the day of the test, each mouse was gently removed from its home cage and put immediately in the center of the OF. They were allowed to explore the arena for $10 \mathrm{~min}$ freely. All trials were recorded and analyzed automatically (in a live mode) by the AnyMaze software (Stoelting, Germany). The distance traveled (meters) was recorded as a measure of basal locomotor activity. 


\section{Tail-suspension test (TST)}

The TST, a classical animal model used to evaluate passive and active coping behavior, was a modified version of that validated in mice by Steru and colleagues (1985). On the day of the experiments, all experimental groups were transported from the housing facility to the testing room. Then, they were left there undisturbed for at least three $h$. Animals were individually suspended by the tail to a horizontal ring-stand bar (distance from floor $=35 \mathrm{~cm}$ ) using an adhesive tape (distance from the tip of tail $=2 \mathrm{~cm}$ ). Typically, mice demonstrated several escape-oriented behaviors interspersed with bouts of immobility of increasing length as the session progressed. The test session (6 min) was recorded, and the total immobility time was measured by an experienced experimenter blind to the treatment conditions.

\section{Novelty suppressed feeding test (NSF)}

The NSF test is another classical test employed to evaluate anxiety-like behaviors (Campos et al., 2013). The apparatus consisted of a square acrylic box (40 x $40 \times 30 \mathrm{~cm})$ with the floor covered by $2 \mathrm{~cm}$ of sawdust. Twenty-four hours before the test, all animals were food-deprived. On the day of the test, a single regular chow pellet was placed on a white platform located in the center of the arena. Each animal was placed in one of the corners of the apparatus, and the latency to start to eat in the new environment was measured in a 10 min test session. The stopwatch immediately stopped when the mouse bites the chow, using its forepaws and sitting on its haunches. After the test, all animals returned to their home cages and the amount of food consumed in the next 5 minutes was measured.

\section{Splash Test (ST)}

The ST consists of splashing a sucrose solution (10\%) on the mice's dorsal coat in its home cage. After applying the sucrose solution the time spent in a 10 min test session behavior was recorded for 6 min to evaluate the self-care and hedonic behavior. The sucrose solution has sufficient viscosity to evoke self-cleaning behaviors or grooming. Mice exposed to CUS exhibit an impairment in self-cleaning behaviors. Chronic antidepressant treatment prevents stress-induced changes in self-cleaning (Ducottet et 
al.; 2004). Grooming reduction has been correlated with symptoms of MDD such as apathy and reduced self-care. An experimenter blind to the treatment conditions carried out the behavior analyses manually by watching the videos. In the ST, the latency for the grooming first episode after the splash of the sucrose solution in the mice's neck was recorded. The total grooming time, specifically in the face, was analyzed between the $1^{\text {st }}$ and the $6^{\text {th }}$ minute of the test.

\section{Tissue preparation}

Soon after the last behavioral assessment, the animals were euthanized under anesthesia (Ketamine/Xylazine $100 / 8 \mathrm{mg} / \mathrm{Kg} \quad 0.1 \mathrm{ml}$, i.p., Syntec, Brazil). The hippocampus was rapidly dissected ( $n=4-6$ per group), according to Spijker et al. (2011). After that, the samples were lysed in a tissue buffer containing $50 \mathrm{mMTris}(\mathrm{pH} \mathrm{7.6)}$ and a complete proteinase inhibitor (1:10 dilution of stock; Sigma-Aldrich, St. Louis, MO, USA). After homogenization, the supernatant was collected and stored separately at $-80^{\circ} \mathrm{C}$ until further use.

For immunohistochemistry, mice were perfused transcardially with phosphate buffer saline (PBS), followed by a $4 \%$ paraformaldehyde solution for tissue fixation. After that, brains were removed, cryoprotected for $72 \mathrm{~h}$ in a $30 \%$ sucrose solution, and cut in slices of $30 \mu \mathrm{m}$ at the hippocampus region (bregma from -1.46 to $-3.08 \mathrm{~mm}$; Paxinos \& Franklin, 2001) using a cryostat (Criocut 1800, Reichert-Jung, Heidelberg, Germany).

\section{Determination of BDNF levels by ELISA}

The dissected hippocampus was processed in a lysis buffer (50 mMTris ( $\mathrm{pH} 7.6)$ enriched with a proteinase inhibitor cocktail (1:10 dilution of stock; Sigma-Aldrich, St. Louis, MO, USA) in a Tissuelyser (Qiagen, Hilden- Germany). After the lysing procedure, samples were centrifuged twice (10 min, $12000 \mathrm{rpm}$ ), and the supernatant collected and store at $-80^{\circ} \mathrm{C}$ until the begging of the analysis. The samples' total proteins were quantified using the Bradford method (Bio-Rad Laboratories, Hercules, CA, USA). Proteins extracted from hippocampal samples were submitted to ELISA protocols to detect BDNF according to the manufacturer's instructions (BDNF Emax Immunoassay System, Promega, Madison, WI, USA). Briefly, 96-well plates were coated with the 
monoclonal anti-mouse-BDNF antibody at $100 \mu \mathrm{l} /$ well. After overnight incubation at $4^{\circ} \mathrm{C}$, the dishes were washed three times with wash buffer. The samples were diluted 1:5 in Dulbecco's PBS, acidified (to approximately $\mathrm{pH} 2.6$ ) with $\mathrm{HCl} 1 \mathrm{~N}$ by $15 \mathrm{~min}$, and incubated in the coated wells $(100 \mu \mathrm{l}$ each) for $2 \mathrm{~h}$ at room temperature with shaking. After five additional washes, the antigen was immobilized with an anti-human BDNF antibody for 2 $\mathrm{h}$ at room temperature with shaking. The plates were rewashed with wash buffer and then incubated with anti-immunoglobulin $\mathrm{Y}(\lg \mathrm{Y})$ horseradish peroxidase for $1 \mathrm{~h}$ at room temperature. After another wash, the plates were incubated with a TMB/peroxidase substrate solution for $15 \mathrm{~min}$, and $1 \mathrm{M}$ phosphoric acid $(100 \mu \mathrm{l} /$ well) was added to the wells. The calorimetric reaction product was measured at $450 \mathrm{~nm}$ using a microplate reader (Victor, Perkin Elmer, MA, United States). BDNF concentrations ( $\mathrm{pg} / \mu \mathrm{g}$ of total protein) were determined from the regression line for the BDNF standard (ranging from 7.8 to $500 \mathrm{pg} / \mathrm{ml}$ purified mouse BDNF) that was incubated under similar conditions in each assay. All assays were performed in duplicate. The final results were expressed against the total protein concentrations.

\section{Western blot}

The protein concentrations in the stored supernatant from the hippocampus were determined using the Bradford method. Twenty micrograms $/ 20 \mathrm{~mL}$ of total proteins were electrophoresed (NuPAGE, Invitrogen, CA, USA). After protein transfer into a nitrocellulose membrane (Amersham Potran, Little Chalfont, United Kingdom), membranes were blocked in 10\% non-fat milk (Bio-Rad) (dissolved in Tris- saline- buffer $+0.5 \%$ of Tween 20, TBSt) for $2 \mathrm{~h}$. After the blocked membranes were rinsed quickly with TBSt to remove the excess of blocking solution and then incubated with the primary antibody at $4{ }^{\circ} \mathrm{C}$ overnight at the following dilutions: anti-BDNF (1:2500; Santa Cruz Biotechnology, CA, USA), anti-CB1 receptor (1:500, Thermo scientific, MA, USA), antiCB2 receptor (1:500, Thermo Scientific MA, USA), anti-GR receptor (1:500, Millipore, MA, USA), anti-PSD95 (1:1,000, Cell Signaling, Danvers, Massachusetts, USA), antisynaptophysin (1:500, Cell Signaling, Danvers, Massachusetts, USA), antisynaptotagmin (1:1,000, Cell Signaling, MA, USA), anti-BDNF (1:500; Santa Cruz Biotechnology, CA, USA), anti-a-tubulin (1:20,000; Sigma-Aldrich, Darmstadt, Germany), 
anti-beta actin (1:20,000, Cell Signaling, MA, USA). After a washing step with TBS, membranes were incubated for two hours with donkey anti-mouse IgG (1:2,000; Amersham Potran, Little Chalfont, United Kingdom). The reactive bands were detected using an enhanced chemiluminescence reagent (ECLPrime $\AA$, Amersham, Little Chalfont, United Kingdom) and visualized using ChemiDoc Imaging Systems (GE ImageQuant LAS, MA- USA). Intensities of specific bands were quantified using Image Studio Lite (LICOR, Nebraska, USA) and normalized to anti- $\alpha$-tubulin protein levels. Data were presented as \% of the Veh group (control).

\section{BrdU and doublecortin (DCX) immunohistochemistry}

The sections containing the hippocampal formation received three washes in TBS. Subsequently, for the BrdU detection, the slices were incubated for 30 min in $2 \mathrm{~N} \mathrm{HCl}$ at $37{ }^{\circ} \mathrm{C}$ for DNA denaturation. After this period, the slices were left for 5 min at $4{ }^{\circ} \mathrm{C}$ and washed three times with $0.1 \mathrm{M}$ boric acid $(\mathrm{pH}=8.9)$, followed by three additional washes with TBS. For DCX detection, slices underwent an antigen retrieval step in citrate buffer (10mM Citric Acid, $0.05 \%$ Tween 20, pH 6.0) for $30 \mathrm{~min}$ at $70{ }^{\circ} \mathrm{C}$. After that, slices were left on the bench for cooling down at room temperature. Slices were then incubated in a blocking solution (BSA 1\%+0.25\% Triton 100X in TBS) for $2 \mathrm{~h}$. Afterward, the slices were incubated overnight with the primary antibody rat anti-BrdU (1:100, Abcam, MA, USA) or goat anti-DCX (1:200, Santa Cruz Biotechnology, CA, USA) and subsequently incubated with the respective secondary antibodies for $1 \mathrm{~h}$ (1:1,000, Alexa-Fluor anti-rat 488, Invitrogen, Carlsbad, CA, USA, or 1:1,000 Vectastin anti-goat biotinylated). In the case of $D C X$ staining, we performed an additional step of incubation with $A+B$ complex for one hour (1:1,000, ABC Elite-Vectastin kit, Vector Labs, Burlingame, CA, USA) followed by the color development using 3,3 '-Diaminobenzidine $(0.2 \mathrm{mg} / \mathrm{ml}, 10 \mathrm{~min}$, Sigma-Aldrich, Missouri, USA). For BrdU stained slices, we used Hoechst (Sigma-Aldrich,

Missouri, USA) for total nuclei staining. At the end of the immunofluorescence/immunohistochemistry procedures, slices containing hippocampi were mounted on glass slides/coverslips with Cytoseal60 (BrdU, Electron Microscopy Science, Hatfield, PA, USA) or Permount (DCX-Fisher Scientific, Loughborough, United Kingdom) as mounting media. 


\section{Microcopy, BrdU, and DCX analysis}

Six to eight slices containing dorsal parts of the hippocampus were analyzed for each experimental animal. BrdU+ and DCX+cells were counted in a 40x objective by an experimenter blind to the treatment conditions. For BrdU quantification, a confocal microscopy (TCS-SPE, Leica, Wetzlar-Germany) was used. BrdU+ cells were counted in the subgranular zone (SGZ) of the dentate gyrus (DG) of the hippocampus. Z-stacks images obtained from $20 \mathrm{~mm}$ were projected as a 3D image (BrdU + Hoescht positive cells). A light microscope Olympus AX-70 (Olympus, Tokyo, Japan) was used to count DCX+ cells. A cell was considered positive for DCX only if the cell body was stained, and cells were located in the SGZ of the DG. DCX+ cells were also considered as migrating cells if they were in the granular zone of the DG. The total number of cells was normalized to the DG area determined with a $10 \times$ objective. The number of positive cells was estimated by calculating the total hippocampal volume, as determined by the sum of the areas of the sampled sections multiplied by the distances between them (Campos et al., 2013). Total cells were expressed as the total amount of positive cells $/ \mathrm{mm}^{3}$ of DG.

\section{Statistical analysis}

Data obtained were tested for normality (Kolmogorov-Smirnov's est), homogeneity of variance (Levene's test). Behavioral, ELISA and immunohistochemical data were analyzed by Student's t-test (Stress effects: Veh control vs. Veh stressed group) and twoway ANOVA (treatment 1-AM251 or Veh; treatment 2- antidepressants or Veh within the stressed group) followed when appropriated, by the Duncan post-test. WB was analyzed by one-way ANOVA. Besides two-Away ANOVA, we also ran the Friedman nonparametric test. The significance level was set at $p<0.05$. Data were expressed as mean \pm SEM. Statistical analysis was performed by SPSS version 16.0 software (IBM, USA).

\section{Results}

Repeated treatment with AM251, a CB1 receptor antagonist/inverse agonist, did not change the behavioral effects of ESC or VLX in mice submitted to CUS. 
Figure 2 (A-D) illustrates the effects of pre-treatment with AM251 in the behavioral effects of Esc in the TST and NSF. In the TST, chronic-stress induced increased immobility time when compared to the control-vehicle group $(\mathrm{t}(26)=2.3, \mathrm{p}<0.05)$. Chronic treatment with Esc in stressed mice, decreased the immobility time in CUS-mice $\left(F_{(1,47)}=\right.$ 3.77, $p=0.05$ ). No effects of AM251 (treatment 2) or the combination of ESC+AM251 were found $\left(F_{(1,47)}=0.93, p=0.340\right)$. In the NSF (Figure $2 C$ ), stress increase the latency of feeding in the new environment $\left(t_{(26)}=2.97, p<0.01\right)$. Esc, with or without AM251 pretreatment, decreased chronic-stress induced increased latency to feed in a new environment (effect of treatment 2 - Veh or ESC- $\left(F_{(1,50)}=15.90, p<0.001\right)$ without changing the parameters of feeding behavior in the home-cage. No effects of AM251 or the interaction between treatments were found $\left(F_{(1,50)}=0.17, p=0.674\right)$. No changes in the basal locomotor activity measured in the OF test were observed in any condition or treatment.

A.

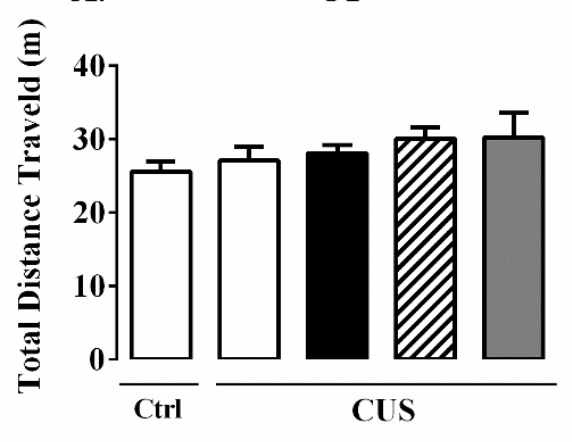

C.

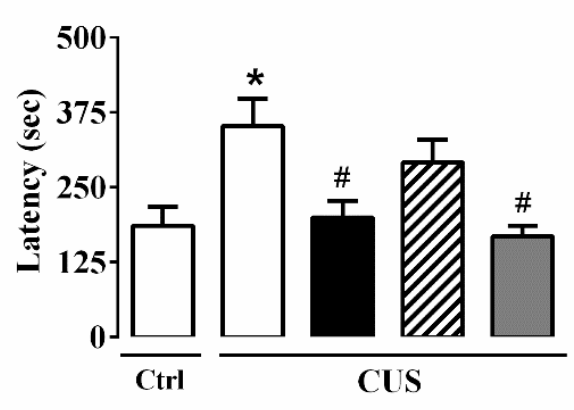

B.

TST

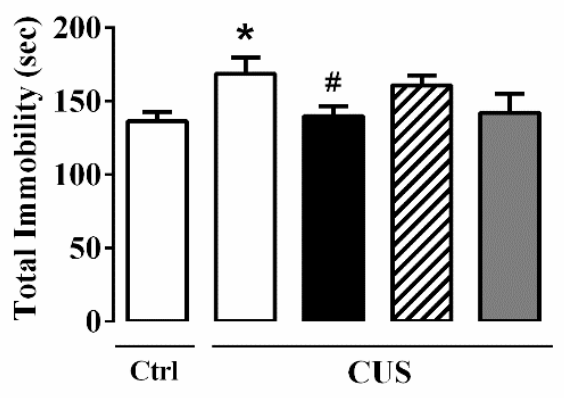

D.

NSF

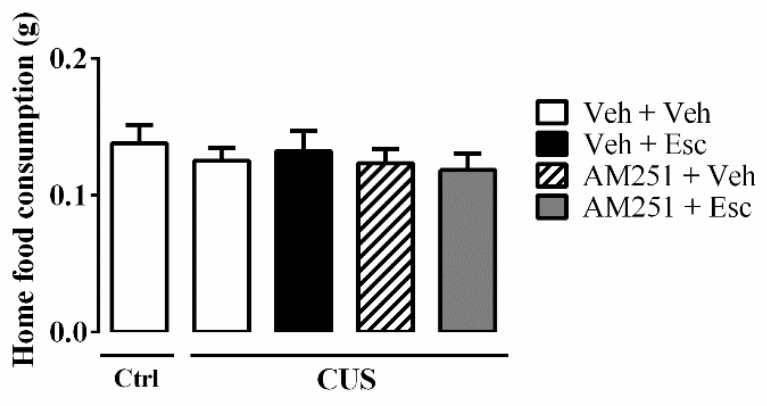

Figure 2. Chronic CB1 receptor blockade attenuated the positive coping behavioral effects of escitalopram (Esc) in the tail suspension test (TST) but not in the novelty suppressed feeding (NSF). A- Open field (OF) test, B- total immobility time in the TST, C- 
Latency to feed in a new environment in the NSF test, D- home cage food consumption in the NSF. Bars represent mean +/- SEM. *indicates the difference from the control group. \#represents differences from the stressed-vehicle group. ( $N=13-14 /$ group).

Figure 3 represents the results of the VFX and AM251 and their combination in the NFS and ST. In the NSF, stress was not able to increase the latency to feed $\left(t_{(5,95)}=1.44\right.$, $p=0.266$ ). However, VFX was able to decrease the latency to feed in the new environment (treatment $\left.2 F_{(1,25)}=4.2, p<0,01\right)$. This effect was not antagonized by AM251 (Two-Way ANOVA; interaction treatment 1 vs treatment $2-F_{(1,25)}=9.7, p<0.001$; Friedman test $\left.\mathrm{df}=2 ; \chi^{2}=49.5, \mathrm{p}<0.001\right)$. In the $\mathrm{ST}$, despite no changes in the total grooming behavior, CUS decreased the facial grooming behavior. Besides, VFX was able to prevent stress-induced decreased facial grooming behavior $\left(F_{(1,25)}=4.7, p<0.05\right)$. Although we observed a trend $\left(F_{(1,25)}=3.36, p=0.08\right)$, AM251 did not change facial grooming latency. No significant interaction effect between treatments were found $\left(F_{(1,25)}=\right.$ $1.2, p=0.27)$.

A. 1st grooming episode - ST

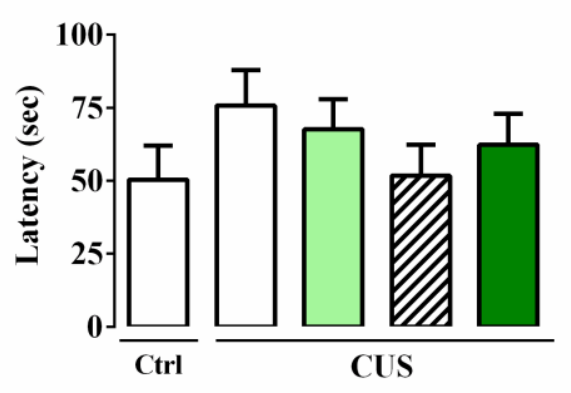

C.

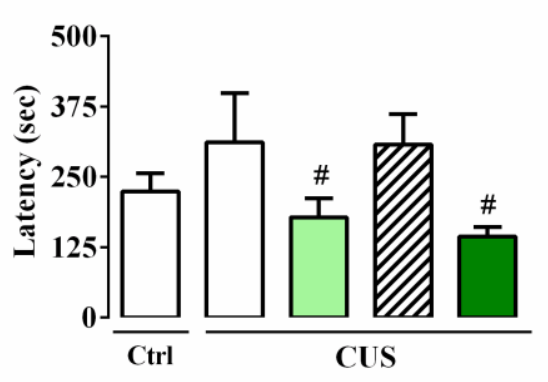

B.

ST

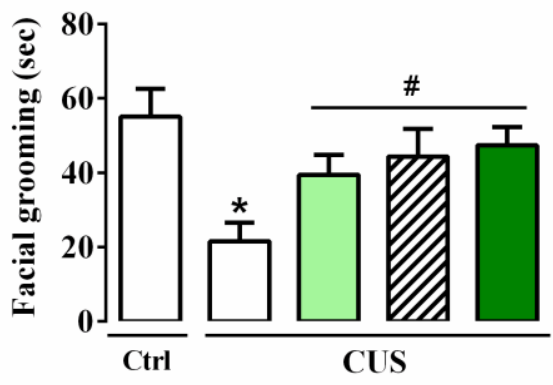

D.

NSF

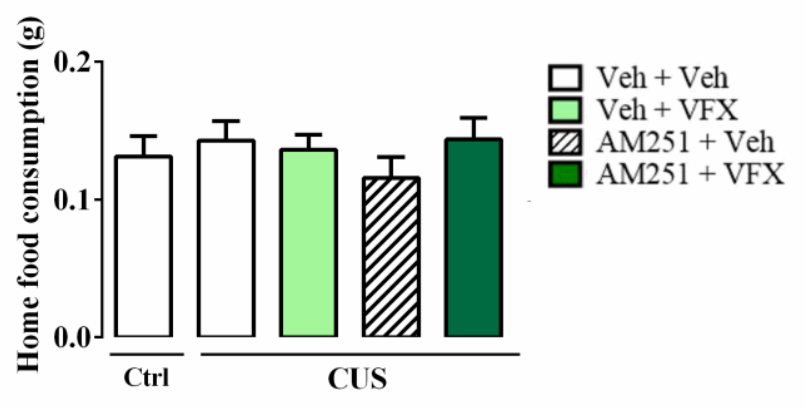


Figure 3. Venlafaxine (VFX) prevents stress-induced anhedonia and anxiety-like behaviors. This effect was not attenuated by AM251. A-latency for the first episode of grooming in the Splash Test (ST), B- Facial grooming duration in the ST, C- Latency to feed in a new environment in the NSF test, D- home cage food consumption in the NSF. Bars represent mean +/- SEM. * indicates the difference from the control group. \# represents differences from the stressed-vehicle group. ( $N=7-8 /$ group).

Esc increased the expression of CB1 and decreases the expression of Glucocorticoid receptors in the hippocampus

As illustrated in figure 4, repeated treatment with Esc in stressed animals increased CB1 expression in the hippocampus, an effect prevented by the pre-treatment with AM251 in stressed animals $\left(F_{(3,14)}=19.7, p<0.05\right)$. On the other hand, Esc, AM251, or their combination prevented the stress-induced increased expression of GR receptors in the hippocampus $\left(F_{(3,15)}=4.73, p<0.05\right)$. 

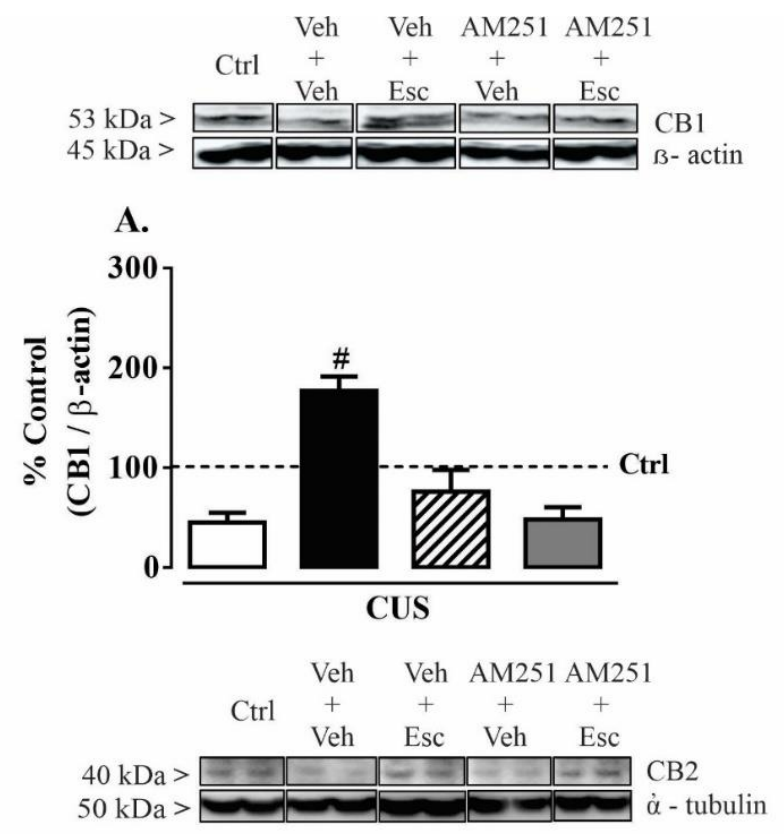

B.
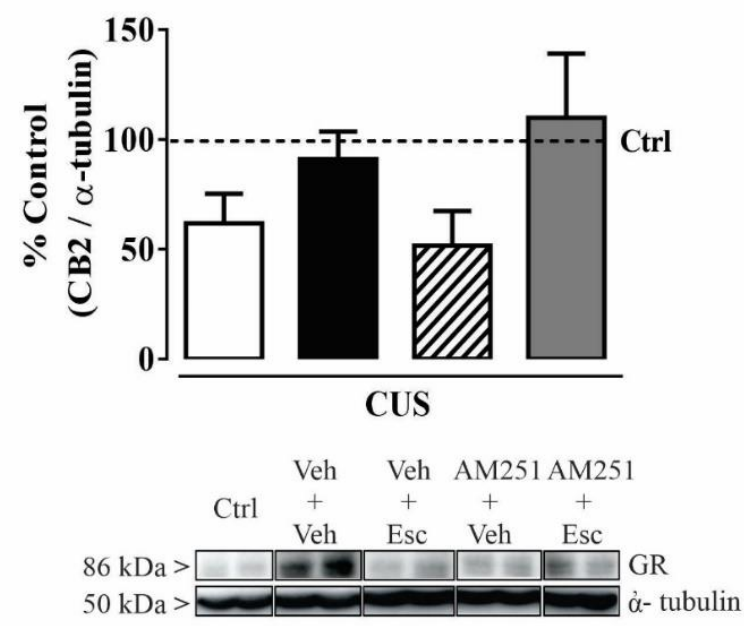

C.

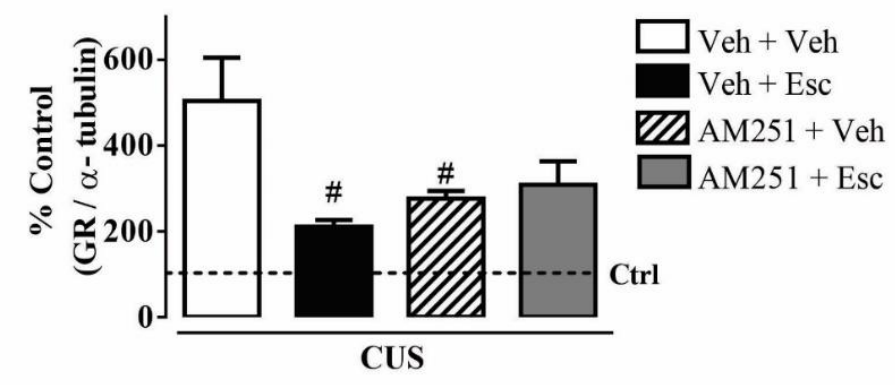

Figure 4. Escitalopram (Esc) facilitates $C B 1$ but reduces $G R$ expression in the hippocampus of chronically stressed mice. A - CB1, B - CB2, and C - GR levels in the hippocampus. Data represented as \% of control (Ctrl - dot line). Bars represent mean +/SEM. \#indicates the difference from the stressed-vehicle group. $(\mathrm{N}=4-5)$. 
Pre-treatment with AM251 did not change the pro-proliferative effects of Esc in the dentate gyrus

Stress did not significantly reduce cell proliferation in the $D G(t(6)=1.9, p=0.09)$. However, Esc facilitated cell proliferation in the dentate gyrus (DG) of the hippocampus as demonstrated by the increase in BrdU positive cells in the figure 4 (treatment 2; $F_{(1,12)=}$ 11.2, $p<0.01$, figure 5). AM251 did not antagonize the proliferative effect (treatment 1 vs treatment $\left.2 ; F_{(1,12)}=1.2, p=0.3\right)$. In the case of BDNF, no statistical differences between groups treated with $\mathrm{Veh} / \mathrm{Veh}$ were observed $(\mathrm{t}(4.6)=0.03, p=0.9)$. Likewise, Esc and AM251 (treatment $1 ; F_{(1,13)}=0.2$; treatment $2 ; F_{(1,13)}=0.5 ; p>0.05$ ) or their combination did not change BDNF levels in the hippocampus (treatment 1 vs treatment 2; $\left.F_{(1,13)}=3.4, p=0.08\right)$. However, CUS-Esc group seems to have increased levels of BDNF in the hippocampus when compared to the Veh/Veh non-stressed group (OneWay ANOVA; $F(4,17)=2.8, p=0.06)$.

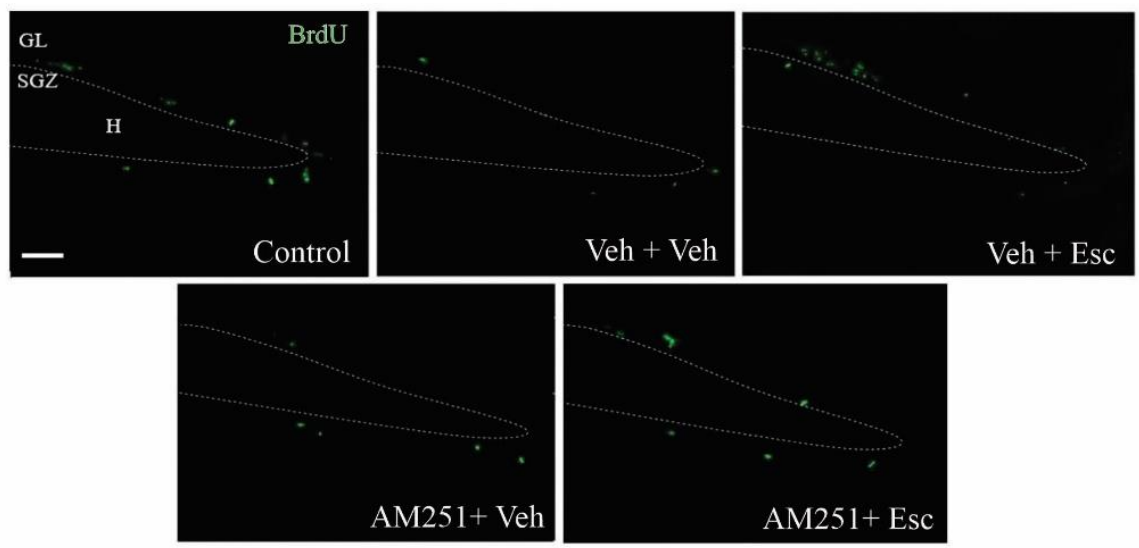

A.

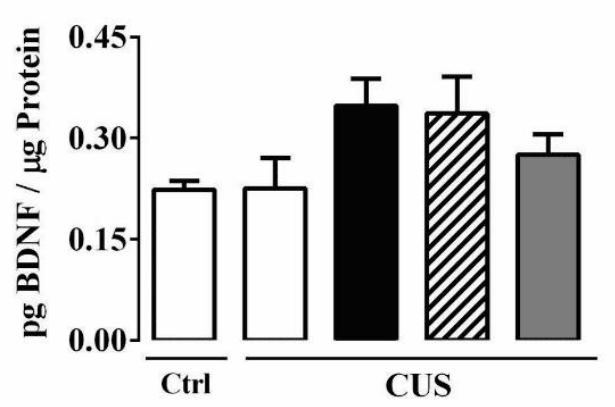

B.

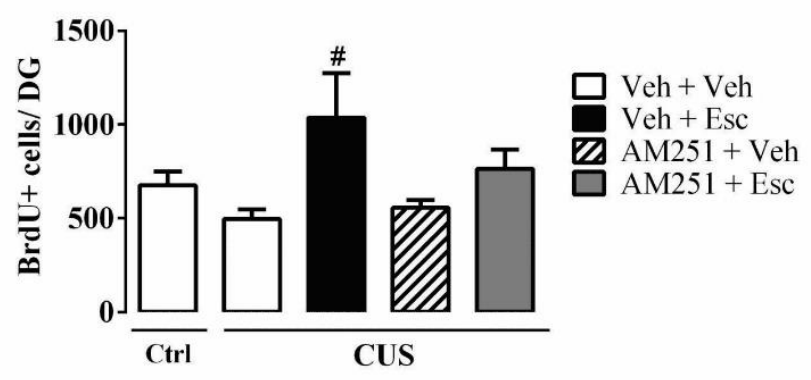


Figure 5. Effects of stress and escitalopram (Esc) treatment in the A- BDNF levels in the hippocampus, and B- cell proliferation in the dentate gyrus (DG) of the hippocampus $(\mathrm{H}-$ hilus; SGZ- subgranular zone; GL- granular layer). Bars represent mean +/- SEM. \# indicates the difference from the stressed-vehicle group. ( $N=3-5$ / group). Magnification (20x. The bar represents $50 \mu \mathrm{m}$.

In the dentate gyrus of chronically stressed mice, AM251 or VFX treatment did not affect the profile of the $D C X+$ cell

Stress did not change the total number of DCX + cells $(t(16)=0.217, p=0.83)$ nor the percentage of migrating $D C X+$ cells in the granular layer $(t(17)=0.355, p=0.72)$, as observed in the figure 6. The two-way ANOVA did not reveal any effect on the number of DCX + cells present in the dentate gyrus of any treatment alone: AM251 $(F(1.11)=0.154$, $p>0.05)$ and $\operatorname{VFX}\left(F_{(1.11)}=2.635, p>0.05\right)$, or any interaction between treatments $(F$ $(1.11)=0.575, p>0.05)$. Likewise, regarding percentage of $D C X+$ migrating cells, there was no differences between any of the treatment-independent groups: AM251 $\left(F_{(1.11)}=\right.$ 1.362, $\mathrm{p}>0.05)$ and $\operatorname{VFX}\left(\mathrm{F}_{(1.11)}=0.051, \mathrm{p}>0.05\right)$ or the interaction between the treatments $\left(F_{(1.11)}=0.0116, p>0.05\right)$.

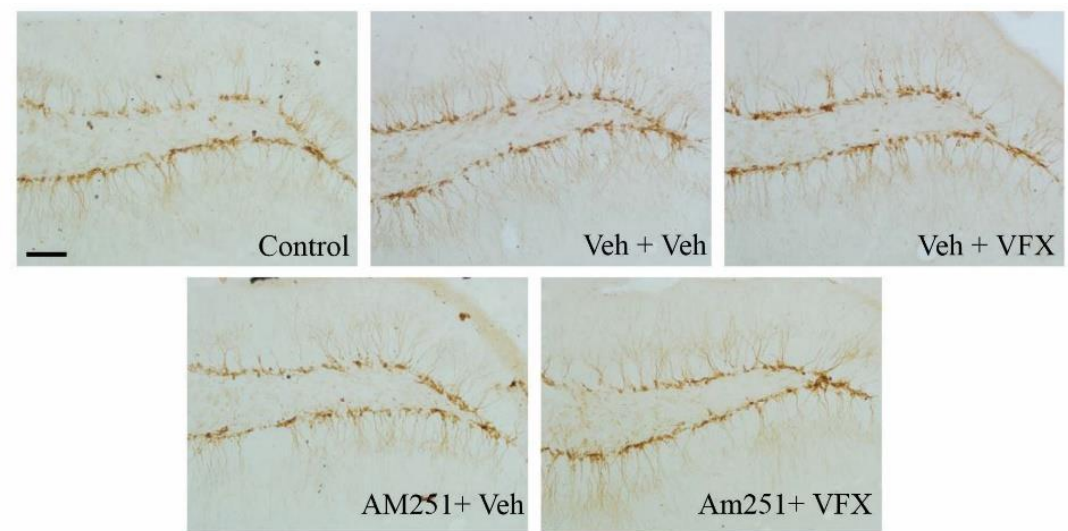

A.

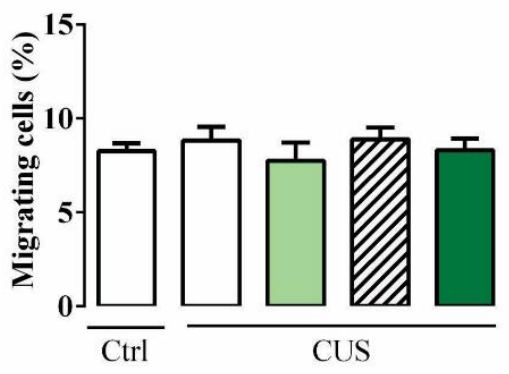

B.

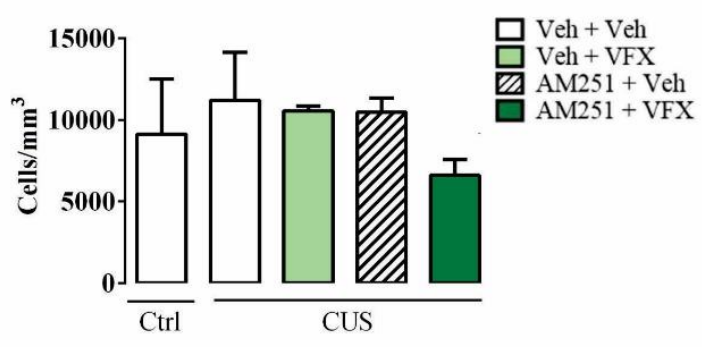


Figure 6. Effects of stress and venlafaxine (VFX) treatment in the A- The migrating process of doublecortin (DCX) positive cells in the granule cell layer of the hippocampus, and B- Total DCX cells in the dentate gyrus of the hippocampus. Bars represent mean + - SEM. ( $N=3-5 /$ group). Magnification (20x) bar represents- $50 \mu \mathrm{m}$.

The CB1 receptor is involved in the effects of Esc in facilitating the expression of $P S D$ 95, but not presynaptic proteins, in the hippocampus

In figure 7C, we observe a trend in Esc increases the expression of PSD-95 $\left(F_{(3,14)}=2.1, p=0.06\right.$; One-way ANOVA $)$ in the hippocampus, an effect attenuated by AM251. On the other hand, in the case of the synaptic protein synaptophysin, Esc facilitates its expression. However, the pre-treatment with AM251 did not influence this effect $\left(F_{(3,14)}=11.5, p<0.05\right.$, Figure $\left.7 B\right)$. No differences in the expression of synaptotagmin were found (Figure 7A). 


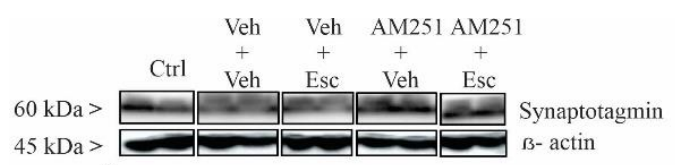

A.
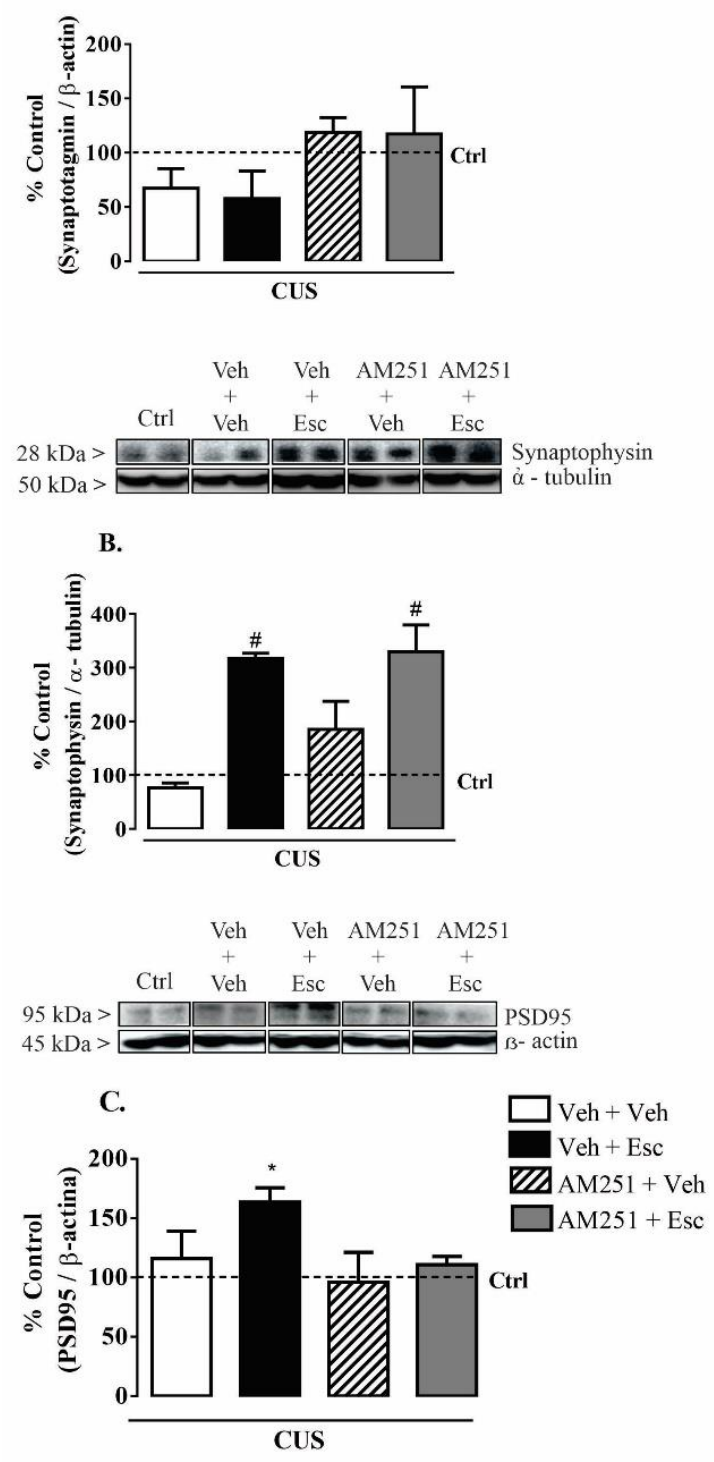

Figure 7. Effects of chronic stress and the treatment with escitalopram (Esc), or AM251 in the expression of pre and postsynaptic proteins. A - Synaptotagmin, B Synaptophysin, and C - PSD-95 levels in the hippocampus. Data represented as \% of control (Ctrl - dot line). Bars represent mean $+/$ - SEM. * indicates the difference from the AM251 + Veh and AM251 + Esc groups. ( $N=3-5 /$ group).

\section{Discussion}

The results of the current study indicated that repeated Esc and VFX treatment decreased anxiety and despair-like behaviors that were induced by stress. Moreover, our results also demonstrated that Esc increased the cell proliferation rate and affected the 
expression of cannabinoid CB1 receptor, GR, synaptophysin and PSD95 in the hippocampus. In order to investigate whether the anxiolytic and antidepressant-like behaviors induced by Esc and VFX are modulated by cannabinoid system, we tested mice submitted to CUS paradigm and treated with cannabinoid CB1 inverse agonist, AM251, following antidepressant administration. Firstly, we conducted one experiment to evaluate the involvement of $\mathrm{CB} 1$ receptor in the long-term effects of Esc. Our results in this experimental design indicated that the decrease in passive coping strategies of Esc was attenuated by the pre-treatment with AM251 in the TST. In a different way, the anxiolytic effect in the NSF was not affected by co-administration of AM251. After that, we conducted another experiment to evaluate the long-term effect of the coadministration of AM251 and VFX. In the ST test our results indicated that the antidepressant-like effect of VFX was not influenced by pre-treatment with AM251. In the same way of Esc, when the animals were submitted to NSF, the effects of VLX were sustained with co-administration of AM251.

Our behavioral results indicate that the $\mathrm{CB} 1$ receptor is involved in the anti-stress effects of Esc, an SSRI, but not, VFX, an SSNRI. Several studies have suggested that the CB1 receptor and other components of the endocannabinoid system seem to be upregulated after chronic treatment with $A D$ in mice submitted to homotypic stress (Hill et al., 2006a, 2006b; 2008; 2009). Conversely, Poleszak et al. (2019), have demonstrated that acute administration of AM251 potentiated the antidepressant-like effect of Esc in rats submitted to the forced swimming test. Herein, we observed an attenuation of antidepressant-like effect in the TST with repeated Esc and AM251 treatment under stress conditions. This fact could be related to the cross-talk mechanisms between brain CB1 receptor and serotoninergic systems.

The 5- $\mathrm{HT}_{1 \mathrm{~A}}$ receptor is the serotonergic receptor more likely to be directly linked with the antidepressant effects of SSRIs (Celada et al., 2004). Preclinical studies have shown an increase of $5-\mathrm{HT}_{1 \mathrm{~A}}$ receptor-mediated hippocampal transmission after longterm treatment with SSRIs and other antidepressant drug classes (Haddjeri et al., 1998). A notable finding in a study performed by Mato et al. (2007) showed that CB1 receptors' deletion reduced the hypothermic response induced by the 5-HT $\mathrm{H}_{1 \mathrm{~A}}$ agonist 8-hydroxy-2(di-n-propylamino)tetralin (8-OH-DPAT). This result suggests that genetic inactivation of 
the $\mathrm{CB} 1$ receptor might alter the expression and functionality of $5-\mathrm{HT}_{1 \mathrm{~A}}$ receptors. In the same way, our proposal in this study is that chronic inactivation of the CB1 receptor alters the functionality of the $5-\mathrm{HT}_{1 \mathrm{~A}}$ receptor and, in consequence, affects the antidepressant activity of Esc.

Regarding VFX, our results suggest that the antidepressant-like effect of VFX occurs in an independent fashion of CB1 activation. Beyond antidepressant-like effect elicited via serotonergic neurotransmissions, VFX promotes its effects by modulating noradrenergic and even dopaminergic receptors in a sequential manner (Muth et al., 1991; Andrews et al., 1996; Harvey et al., 2000). Besides, VFX potentiates electrophysiological activity in noradrenergic neurons of the locus coeruleus (Haskins et al., 1985), a mechanism that can be relevant for its antidepressant effects. Thus, VFX extensive modulation on monoaminergic pathways could explain the absence of interacting effects between VFX and AM251.

Chronic stress is associated with a down-regulation of CB1 receptor signaling (Hill \& Gorzalka, 2005; Hill et al., 2008b; Reich et al., 2009; Hu et al., 2011; Lee \& Hill, 2013). Our results suggested that the repeated administration of Esc facilitates the expression of CB1 receptors in the hippocampus. This agrees with the study by Smaga et al. (2017), showing that Esc chronic treatment increased the expression of $C B 1$ receptor in the same structure in rats. However, the mechanisms by which antidepressants regulate the CB1 receptor expression are still unclear. It has been suggested that tricyclic antidepressants, such as desipramine, may also increase the intracellular transport and expression of $\mathrm{CB} 1$ receptors in the cell membrane, enhancing the functional activity of CB1 receptors (Hill et al., 2006c). Therefore, we hypothesize that AM251 affecting the intracellular transport of CB1 receptors in the cell membrane could prevent some of the effects of Esc evaluated in the present study.

We also observed that the $\mathrm{CB} 1$ receptor impacted the pro-proliferative effects of Esc in the DG using the thymidine analog BrdU. Regulation of adult hippocampal neurogenesis occurs at different stages, including cell proliferation, differentiation, and survival. Among the regulatory factors of neurogenesis, stress has been identified as a potential inhibitor of dentate cell proliferation (Gould et al., 1998; Czéh et al., 2001; Kempermann, 2002). Furthermore, increased cell proliferation is observed as a response 
to the administration of different classes of antidepressants, and it may contribute to the anti-stress effect of these drugs (Malberg et al., 2000; Malberg \& Duman, 2000). In agreement, facilitation of endocannabinoid signaling induces the pro-proliferative effects of neural progenitor cells (Jin et al., 2004; Aguado et al., 2005, Campos et al., 2013). On the other hand, genetic deletion of $\mathrm{CB} 1$ receptors in mice leads to a $50 \%$ reduction in the BrdU positive cells in the hippocampus, suggesting that the activation of CB1 receptors in the neurogenic niche is an important regulator of adult neurogenesis (Jin et al. 2004). Therefore, the diminished proliferation in the DG found in our study agrees with previous findings showing that impaired CB1 signaling negatively impacts the neurogenic niche.

Corticoids play a crucial regulatory role in progenitor cell proliferation in neurogenic niches. Manipulation of circulating corticoids leading to enhanced glucocorticoid signaling dampens proliferation of progenitor cells in the DG (Gould et al., 1992; Cameron \& Gould, 1994). Otherwise, after adrenalectomy, for example, the absence of circling corticoids prompts this process (Gould et al., 1992; Cameron \& Gould, 1994). The specific mechanisms by which glucocorticoid hormones modulate such regulation are not entirely understood. The mineralocorticoid (MR) and glucocorticoid (GR) receptors are abundantly expressed in the hippocampus (De Kloet et al., 1987; Herman et al., 1993). Several lines of evidence indicate an interplay between glucocorticoids and the endocannabinoid system to control the negative feedback regulation of the hypothalamicpituitary-adrenal (HPA) axis and regulation of adaptive responses of coping stress (Hillard et al., 2016). Glucocorticoid activation, induced by stressful situations or treatment with corticosterone, evokes endocannabinoid-mediated suppression of neurotransmission in the hippocampus (Wang et al., 2012). Likewise, the cross-talk between both systems appears not to be exclusive of the hippocampus. The activation of CB1 receptors in the PFC facilitates HPA axis negative feedback, for instance (Hill et al., 2011; Wang et al., 2012). Thus, the mechanism by which $C B 1$ antagonism attenuated the increase of cell proliferation induced by Esc might be related to the modulation of corticoid signaling. In parallel with enhanced proliferation in DG, our results also demonstrated that chronic treatment with Esc decreases the expression of GR in the hippocampus, an effect attenuated by the association with AM251. These results suggest that the antidepressant, pro-neurogenic, and anti-stress of Esc effects depend on the CB1 activation. 
Concerning neuroplastic effects of repeated treatment with ADs, we also evaluated the cell population positively labeled with doublecortin $(D C X+)$, a microtubule protein closely associated with the immature neuronal phenotype (Couillard-Despres et al., 2005). We found no differences regarding the total number of DCX+ cells or the percentage of migrating DCX+ cells in chronically stressed mice treated with VFX, although the literature report stress as a negative modulator of DCX+ expression (Oomen et al.; 2007; Fogaça et al.; 2018). However, except for their migratory ability, data addressing the exact role of DCX+ cells during neurogenic events are scarce. In this sense, Kempermann and collaborators indicated that DCX+ cells may be responsible for a complex modulation of the microenvironment in neurogenic niches, mediating connectivity between different regions of the DG (Kempermann et al., 2015). The amount of $D C X+$ cells is not necessarily related to ADs behavioral effects. Instead, the microenvironment modulation promoted by $D C X+$ could be more relevant to the ADs effects than its absolute number (Wang et al., 2008). However, it is relevant to mention that Wang et al. (2008) showed that fluoxetine is able to restore the dendritic arborization of DCX+ cells observed in chronically stressed-mice without changing the total number of these cells. Although we have observed no effect on DCX+ cells in our study, their participation in the anxiolytic- and antidepressant-like effects observed cannot be ruled out without new experiments aiming to test this hypothesis.

Neuroplastic changes are proposed as a critical factor of AD mechanisms at cellular and molecular levels. Changes in the number of newly generated cells at different neurogenesis could work as a refined mechanism of neuronal circuitry modulation, modifying the microenvironment and modulating synaptic communication. Synaptophysin and postsynaptic density protein 95 (PSD-95) have been implicated in mechanisms of activity-dependent neuroplasticity underlying different psychiatric disorders (Eastwood et al. 1995; Honer et al. 1999; Coley \& Gao, 2018). PSD-95 is an essential scaffolding protein of the postsynaptic density at excitatory synapses (Lin et al., 2006), while synaptophysin is a marker of pre-synapse development and activity (Wiedenmann \& Franke, 1985). The expression of synaptophysin and PSD-95 markedly decreases in the hippocampus after stress exposure (Thome et al., 2001; Li et al., 2015; Qiao et al., 2017). Esc increased the expression of both proteins in the hippocampus, which may restore the 
basal synaptic function. These findings corroborate those described by Li et al. (2015), showing that the expression of both proteins in the hippocampus increased after treatment with Esc in stressed rats.

AM251 attenuated PSD-95 expression in the hippocampus of stressed rats. PSD95 protein plays a crucial role in the retrograde synaptic signaling elicited by the CB1 receptor to regulate the activity-dependent inhibition of synaptic strength in the brain (Kim et al., 2008; Chen et al., 2011). Thus, It is possible, then, that AM251 is interfering with the behavioral effects of Esc by preventing the increase in PSD-95.

In summary, the present study shows that the CB1 receptor blockade influenced the antidepressant-, but not the anxiolytic-like effect of Esc. This blockade, however, did not modify the effects of VFX, an SRNI. CB1 receptor antagonism also interfered in hippocampal proliferation rate and synaptic markers. Our results bring new pieces of evidence for understanding the role of CB1 receptors in the anti-stress effect of antidepressants.

\section{Acknowledgments}

We would like to thank Eleni Tamburus and Giuliana Bertozi for their excellent technical support. We want to express our gratitude to our lab colleagues for keeping an amazing and collaborative environment. This study was supported by a FAPESP Young Investigator Grant (2015/05551-0), L'Oreal-UNESCO-Brazilian Academy of Science for Women in Science Fellowship, and, CNPq Universal Grant line A (400033/2016-0). RPA received a CAPES scholarship. MAR is a CAPES fellowship. FFS is a FAPESP fellowship (2019/09178-3). 


\section{References}

Aguado T, Monory K, Palazuelos J, et al. 2005. The endocannabinoid system drives neural progenitor proliferation. FASEB J.19(12):1704-1706.

Andrews JM, Ninan PT, Nemeroff CB. 1996. Venlafaxine: a novel antidepressant that has a dual mechanism of action. Depression. 4(2):48-56.

Alger BE. 2004. Endocannabinoids and their implications for epilepsy. Epilepsy Curr. 4(5):169-173.

Bambico FR, Duranti A, Tontini A, Tarzia G, Gobbi G. 2009. Endocannabinoids in the treatment of mood disorders: evidence from animal models. Curr Pharm Des. 15(14):1623-1646.

Bessa JM, Ferreira D, Melo I, et al. 2009. The mood-improving actions of antidepressants do not depend on neurogenesis but are associated with neuronal remodeling. $\mathrm{Mol}$ Psychiatry. 14(8):764-739.

Blier P, de Montigny C. 1994. Current advances and trends in the treatment of depression. Trends Pharmacol Sci. 15(7):220-226.

Blier P. 2001. Pharmacology of rapid-onset antidepressant treatment strategies. J Clin Psychiatry. 62 Suppl 15:12-17.

Cameron HA, Gould E. 1994. Adult neurogenesis is regulated by adrenal steroids in the dentate gyrus. Neuroscience. 61(2):203-209.

Campos AC, Ortega Z, Palazuelos J, et al. 2013. The anxiolytic effect of cannabidiol on chronically stressed mice depends on hippocampal neurogenesis: involvement of the endocannabinoid system. Int J Neuropsychopharmacol. 2013;16(6):14071419.

Cipriani A, Furukawa TA, Salanti G, et al. 2018, Comparative efficacy and acceptability of 21 antidepressant drugs for the acute treatment of adults with major depressive disorder: a systematic review and network meta-analysis. Lancet. 391(10128):1357-1366.

Celada P, Puig M, Amargós-Bosch M, Adell A, Artigas F. The therapeutic role of 5-HT1A and 5-HT2A receptors in depression. J Psychiatry Neurosci. 29(4):252-265.

Couillard-Despres S, Winner B, Schaubeck S, et al. 2005. Doublecortin expression levels in adult brain reflect neurogenesis. Eur J Neurosci. 21(1):1-14.

Coley AA, Gao WJ. 2018. PSD95: A synaptic protein implicated in schizophrenia or autism?. Prog Neuropsychopharmacol Biol Psychiatry. 82:187-194.

Chen X, Nelson CD, Li X, et al. 2011. PSD-95 is required to sustain the molecular organization of the postsynaptic density. J Neurosci. 31(17):6329-6338.

Czéh B, Michaelis T, Watanabe T, et al. 2001. Stress-induced changes in cerebral metabolites, hippocampal volume, and cell proliferation are prevented by antidepressant treatment with tianeptine. Proc Natl Acad Sci U S A. 98(22):1279612801.

Devane WA, Hanus L, Breuer A, et al. 1992. Isolation and structure of a brain constituent that binds to the cannabinoid receptor. Science. 258(5090):1946-1949.

De Kloet ER, Ratka A, Reul JM, Sutanto W, Van Eekelen JA. 1987. Corticosteroid receptor types in brain: regulation and putative function. Ann N Y Acad Sci. 512:351-361. 
Ducottet C, Aubert A, Belzung C. 2004. Susceptibility to subchronic unpredictable stress is related to individual reactivity to threat stimuli in mice. Behav Brain Res. 155(2):291-299.

Eastwood SL, Burnet PW, Harrison PJ. 1995. Altered synaptophysin expression as a marker of synaptic pathology in schizophrenia. Neuroscience. 66(2):309-319.

Fogaça MV, Galve-Roperh I, Guimarães FS, Campos AC. 2013. Cannabinoids, Neurogenesis and Antidepressant Drugs: Is there a Link?. Curr Neuropharmacol. 2013;11(3):263-275.

Fogaça MV, Campos AC, Coelho LD, Duman RS, Guimarães FS. 2018. The anxiolytic effects of cannabidiol in chronically stressed mice are mediated by the endocannabinoid system: Role of neurogenesis and dendritic remodeling. Neuropharmacology. 135:22-33.

Gould E, Tanapat P, McEwen BS, Flügge G, Fuchs E. 1998. Proliferation of granule cell precursors in the dentate gyrus of adult monkeys is diminished by stress. Proc Natl Acad Sci U S A. 95(6):3168-3171.

Gould E, Cameron HA, Daniels DC, Woolley CS, McEwen BS. 1992. Adrenal hormones suppress cell division in the adult rat dentate gyrus. J Neurosci. 12(9):3642-3650.

Harvey AT, Rudolph RL, Preskorn SH. 2000. Evidence of the dual mechanisms of action of venlafaxine. Arch Gen Psychiatry. 57(5):503-509.

Haskins JT, Moyer JA, Muth EA, Sigg EB. 1985. DMI, Wy-45,030, Wy-45,881 and ciramadol inhibit locus coeruleus neuronal activity. Eur J Pharmacol. 1985;115(23):139-146.

Haddjeri N, Blier P, de Montigny C. 1998. Long-term antidepressant treatments result in a tonic activation of forebrain 5-HT1 A receptors. J Neurosci. 18(23):10150-10156.

Hammen C. 2005. Stress and depression. Annu Rev Clin Psychol. 1:293-319.

Heim C, Nemeroff CB. 1999. The impact of early adverse experiences on brain systems involved in the pathophysiology of anxiety and affective disorders. Biol Psychiatry. 46(11):1509-1522.

Herman JP. 1993. Regulation of adrenocorticosteroid receptor mRNA expression in the central nervous system. Cell Mol Neurobiol. 13(4):349-372.

Hill MN, Ho WS, Sinopoli KJ, Viau V, Hillard CJ, Gorzalka BB. 2006a. Involvement of the endocannabinoid system in the ability of long-term tricyclic antidepressant treatment to suppress stress-induced activation of the hypothalamic-pituitaryadrenal axis. Neuropsychopharmacology. 31(12):2591-2599.

Hill MN, Sun JC, Tse MT, Gorzalka BB. 2006b. Altered responsiveness of serotonin receptor subtypes following long-term cannabinoid treatment. Int $J$ Neuropsychopharmacol. 9(3):277-286.

Hill MN, Ho WS, Hillard CJ, Gorzalka BB. 2008a. Differential effects of the antidepressants tranylcypromine and fluoxetine on limbic cannabinoid receptor binding and endocannabinoid contents [published correction appears in $\mathrm{J}$ Neural Transm. 2009 Feb;116(2):141]. J Neural Transm (Vienna). 115(12):1673-1679.

Hill MN, Carrier EJ, McLaughlin RJ, et al. 2008b. Regional alterations in the endocannabinoid system in an animal model of depression: effects of concurrent antidepressant treatment. J Neurochem. 106(6):2322-2336.

Hill MN, Miller GE, Carrier EJ, Gorzalka BB, Hillard CJ. 2009. Circulating endocannabinoids and $\mathrm{N}$-acyl ethanolamines are differentially regulated in major 
depression and following exposure to social stress. Psychoneuroendocrinology.34(8):1257-1262.

Hill MN, McLaughlin RJ, Pan B, et al. 2011. Recruitment of prefrontal cortical endocannabinoid signaling by glucocorticoids contributes to termination of the stress response. J Neurosci. 31(29):10506-10515.

Hill MN, Gorzalka BB. 2005. Is there a role for the endocannabinoid system in the etiology and treatment of melancholic depression?. Behav Pharmacol. 16(5-6):333-352.

Hillard CJ, Beatka M, Sarvaideo J. 2016. Endocannabinoid Signaling and the Hypothalamic-Pituitary-Adrenal Axis. Compr Physiol. 7(1):1-15.

Honer WG, Falkai P, Chen C, Arango V, Mann JJ, Dwork AJ. 1999. Synaptic and plasticity-associated proteins in anterior frontal cortex in severe mental illness. Neuroscience. 91(4):1247-1255.

Hu W, Zhang M, Czéh B, Zhang W, Flügge G. 2011. Chronic restraint stress impairs endocannabinoid mediated suppression of GABAergic signaling in the hippocampus of adult male rats. Brain Res Bull. 85(6):374-379.

Jiang $\mathrm{W}$, Zhang $\mathrm{Y}$, Xiao $\mathrm{L}$, et al. 2005. Cannabinoids promote embryonic and adult hippocampus neurogenesis and produce anxiolytic- and antidepressant-like effects. J Clin Invest.115(11):3104-3116.

Jin K, Xie L, Kim SH, et al. 2004. Defective adult neurogenesis in CB1 cannabinoid receptor knockout mice. Mol Pharmacol. 66(2):204-208.

Kempermann G. 2002. Regulation of adult hippocampal neurogenesis - implications for novel theories of major depression. Bipolar Disord. 4(1):17-33.

Kempermann G, Song H, Gage FH. 2015. Neurogenesis in the Adult Hippocampus. Cold Spring Harb Perspect Biol. 7(9):a018812.

Kim HJ, Waataja JJ, Thayer SA. 2008. Cannabinoids inhibit network-driven synapse loss between hippocampal neurons in culture. J Pharmacol Exp Ther. 325(3):850-858.

Lee TT, Hill MN. 2013. Age of stress exposure modulates the immediate and sustained effects of repeated stress on corticolimbic cannabinoid $\mathrm{CB}_{1}$ receptor binding in male rats. Neuroscience. 249:106-114.

Li XL, Yuan YG, Xu H, et al. 2015. Changed Synaptic Plasticity in Neural Circuits of Depressive-Like and Escitalopram-Treated Rats. Int J Neuropsychopharmacol. 18(10):pyv046.

Lin $\mathrm{Y}$, Jover-Mengual T, Wong J, Bennett MV, Zukin RS. 2006. PSD-95 and PKC converge in regulating NMDA receptor trafficking and gating. Proc Natl Acad Sci U S A. 103(52):19902-19907.

Marsicano G, Goodenough S, Monory K, et al. 2003. CB1 cannabinoid receptors and ondemand defense against excitotoxicity. Science. 2003;302(5642):84-88.

Malberg JE, Duman RS. 2003. Cell proliferation in adult hippocampus is decreased by inescapable stress: reversal by fluoxetine treatment. Neuropsychopharmacology. 2003;28(9):1562-1571.

Malberg JE, Eisch AJ, Nestler EJ, Duman RS. 2000. Chronic antidepressant treatment increases neurogenesis in adult rat hippocampus. J Neurosci. 20(24):9104-9110.

Mato S, Aso E, Castro E, et al. 2007. CB1 knockout mice display impaired functionality of 5-HT1A and 5-HT2A/C receptors. J Neurochem. 103(5):2111-2120. 
Matsuda LA, Lolait SJ, Brownstein MJ, Young AC, Bonner TI. 1990. Structure of a cannabinoid receptor and functional expression of the cloned cDNA. Nature. 346(6284):561-564.

McEwen BS. 1998. Stress, adaptation, and disease. Allostasis and allostatic load. Ann N Y Acad Sci. 840:33-44.

Maydych V. 2019. The Interplay Between Stress, Inflammation, and Emotional Attention: Relevance for Depression. Front Neurosci. 13:384.

Munro S, Thomas KL, Abu-Shaar M. 1993. Molecular characterization of a peripheral receptor for cannabinoids. Nature. 365(6441):61-65.

Mechoulam R, Ben-Shabat S, Hanus L, et al. 1995. Identification of an endogenous 2monoglyceride, present in canine gut, that binds to cannabinoid receptors. Biochem Pharmacol. 50(1):83-90.

Muth EA, Moyer JA, Haskins JT, Andree TH, Husbands GEM. 1991. Biochemical, neurophysiological, and behavioral effects of Wy-45,233 and other identified metabolites of the antidepressant venlafaxine. Drug Development Research, 23(2):191-199.

Oomen CA, Mayer JL, de Kloet ER, Joëls M, Lucassen PJ. 2007. Brief treatment with the glucocorticoid receptor antagonist mifepristone normalizes the reduction in neurogenesis after chronic stress. Eur J Neurosci. 26(12):3395-3401.

Paxinos G, Franklin KBJ. 2001. The mouse brain: stereotaxic coordinates. 2nd Edition, Academic Press, San Diego.

Poleszak E, Wośko S, Sławińska K, et al. 2019. Influence of the $\mathrm{CB}_{1}$ cannabinoid receptors on the activity of the monoaminergic system in the behavioural tests in mice. Brain Res Bull. 150:179-185.

Qiao H, An SC, Xu C, Ma XM. 2017. Role of proBDNF and BDNF in dendritic spine plasticity and depressive-like behaviors induced by an animal model of depression. Brain Res. 1663:29-37.

Reich CG, Taylor ME, McCarthy MM. 2009. Differential effects of chronic unpredictable stress on hippocampal CB1 receptors in male and female rats. Behav Brain Res. 203(2):264-269.

Santarelli L, Saxe M, Gross C, et al. 2003. Requirement of hippocampal neurogenesis for the behavioral effects of antidepressants. Science. 301(5634):805-809.

Seibenhener ML, Wooten MC. 2015. Use of the Open Field Maze to measure locomotor and anxiety-like behavior in mice. J Vis Exp. 2015;(96):e52434.

Seo MK, Choi CM, Mclntyre RS, et al. 2017. Effects of escitalopram and paroxetine on mTORC1 signaling in the rat hippocampus under chronic restraint stress. BMC Neurosci. 18(1):39.

Steru L, Chermat R, Thierry B, Simon P. 1985. The tail suspension test: a new method for screening antidepressants in mice. Psychopharmacology (Berl). 85(3):367370.

Spijker S. 2011. Dissection of Rodent Brain Regions. In: Li K. (eds) Neuroproteomics. Neuromethods. vol 57, Humana Press, Totowa, NJ.

Smaga I, Zaniewska M, Gawliński D, et al. 2017. Changes in the cannabinoids receptors in rats following treatment with antidepressants. Neurotoxicology. 63:13-20.

Thomas EA, Cravatt BF, Danielson PE, Gilula NB, Sutcliffe JG. 1997. Fatty acid amide hydrolase, the degradative enzyme for anandamide and oleamide, has selective 
distribution in neurons within the rat central nervous system. $J$ Neurosci Res. 1997;50(6):1047-1052.

Thome J, Pesold B, Baader M, et al. 2001. Stress differentially regulates synaptophysin and synaptotagmin expression in hippocampus. Biol Psychiatry. 2001;50(10):809812.

Wang M, Hill MN, Zhang L, Gorzalka BB, Hillard CJ, Alger BE. 2012. Acute restraint stress enhances hippocampal endocannabinoid function via glucocorticoid receptor activation. J Psychopharmacol. 26(1):56-70.

Wang JW, David DJ, Monckton JE, Battaglia F, Hen R. 2008. Chronic fluoxetine stimulates maturation and synaptic plasticity of adult-born hippocampal granule cells. J Neurosci. 28(6):1374-1384.

Wiedenmann B, Franke WW. 1985. Identification and localization of synaptophysin, an integral membrane glycoprotein of $\mathrm{Mr} 38,000$ characteristic of presynaptic vesicles. Cell. 41(3):1017-1028. 
CHAPTER 6

GENERAL DISCUSSION 
In the present work it was demonstrated that selective activation of the postsynaptic 5-HT $1 \mathrm{~A}$ receptor by NLX-101 resulted in functional recovery and enhanced neuroplasticity in mice with cerebral ischemia (Chapter 3). Specifically, NLX-101 impacted positively dendritic remodeling and prevented the decrease of brain-derived neurotrophic factor (BDNF) levels in the prefrontal cortex (PFC) and hippocampus. NLX101 also affected synaptic plasticity proteins, increasing the expression of postsynaptic density protein 95 (PSD-95) and synaptophysin (SYN) protein levels in the hippocampus of ischemic mice. Besides this, it was tested the hypothesis that activation of the postsynaptic 5-HT 1 A receptor by NLX-101 could result in an increase of spatial object pattern separation (OPS) performance in aged rats (Chapter 4). In this study it was demonstrated that acute or repeated treatment with NLX-101 resulted in a significant cognitive improvement of aged rats in the OPS task. This effect was accompanied by an increase in hippocampal neurogenesis as well as in BDNF and PSD-95 protein levels in the hippocampus of those animals.

It was addressed in this thesis whether the selective activation of the $5-\mathrm{HT} 1 \mathrm{~A}$ receptor using the biased agonist NLX-101, could result in functional recovery and an increase in neuroplasticity in two different conditions (cerebral ischemia and aging). This hypothesis was developed based on preclinical studies that demonstrated that nonbiased agonists promote significant positive effects on the consequences of cerebral ischemia, although clinical studies with repinotan (a full agonists) have not shown any benefits (see chapter 2). The problem behind this issue is that classic agonists indiscriminately activate both auto-receptors, which exert an inhibitory effect on serotonergic tone, and heteroreceptors in projecting areas that presents positive effect on neuroprotection. In contrast biased agonists that preferentially activate either raphelocated 5-HT1A autoreceptor or post-synaptic heteroreceptor may yield a more favourable therapeutic profile accompanied by lower incidence of side effects, compared with non-biased agonists. The preferential targeting by biased agonists of raphe-located $5-\mathrm{HT}_{1 \mathrm{~A}}$ autoreceptors or post-synaptic heteroreceptors is not due to differences in the receptor protein itself. The distinct responses to $5-\mathrm{HT}_{1 \mathrm{~A}}$ biased agonists are probably attributable to regional coupling differences of the $5-\mathrm{HT}_{1 \mathrm{~A}}$ receptors to certain G-protein subtypes, regulators of G-protein signalling, or transcriptional regulation (Newman- 
Tancredi, 2011). This conformity results in similar receptors which only differ with regard to coupled $\mathrm{G}$ proteins, hence the difference in responses of F13714 and F15599 upon the receptors are purely related to the effect that the compounds generate upon the receptors and not on the binding affinity per se. Different studies have demonstrated that F15599 preferentially activates post-synaptic 5- $\mathrm{HT}_{1 \mathrm{~A}}$ heteroreceptors over raphelocated autoreceptors (Newman-Tancredi et al., 2009; Assié et al., 2010; Depoortère et al., 2010). F13714 exerts an opposite pharmacological profile with more pronounced activity at raphe-located autoreceptors, and only modest activation at postsynaptic heteroreceptors (Assié et al., 2006; Newman-Tancredi, 2011).

Experimental evidence shows that $5-\mathrm{HT}_{1 \mathrm{~A}}$ receptors participate in the regulation of neuroplastic processes in the adult brain. This include neurochemical responses that alter synaptic function (increase or decrease in the number of receptors, changes in the synthesis or release of neurotransmitters or changes in synaptic stability), synaptic strength, synaptogenesis, neurogenesis, gliogenesis and changes in dendritic morphology (size and number of dendritic tree branches, variation in density and morphology of dendritic spines) (Bruel-Jungerman et al., 2007; Gulyaeva, 2017; Dan, 2019). Linked to this, $5-\mathrm{HT}_{1 \mathrm{~A}}$ receptors have been involved in the modulation of long-term potentiation (LTP), a phenomenon characterized by the persistent increase in synaptic strength after high-frequency stimulation that has been related to learning and memory function (Bliss and Collingridge, 1993).

The hippocampus and PFC play a central role in spatial learning, memory and emotional control, which has been closely related to the plasticity of dendritic arborization and morphological changes (Knafo et al., 2004; Frankfurt and Luine, 2015; Milner and Klein, 2016). Brain ischemia has a profound effect on the structure and function of synapses that is associated with impairments in neurological functions such as cognitive and emotional impairments (Hasbani et al., 2000; He et al., 2012). Accordingly, in Chapter 3 it was demonstrated that cerebral ischemia negatively impacted dendritic remodeling in the hippocampus and PFC of mice. This finding could be related to the cognitive and emotional deficits observed in those animals. In this perspective, repeated administration of NLX-101 impacted positively dendritic remodeling in the hippocampus and PFC of ischemic mice resulting in functional recovery observed in several behavioral tasks. 
These data are in agreement with other studies demonstrating that agonists of the $5-\mathrm{HT}_{1 \mathrm{~A}}$ receptor stimulates dendritic remodeling in the hippocampus and in cortical regions. Yan et al. (1997) have demonstrated a reduction in the dendritic length and density of dendritic spines of the granular neurons of the hippocampus in rats in the early postnatal period with absence of $5-\mathrm{HT}$. These effects were prevented by the administration of the $5-\mathrm{HT}_{1 \mathrm{~A}}$ receptor agonist buspirone. Also 8-OH-DPAT promoted an increase in the number and length of dendrites in neuro $2 \mathrm{~A}$ cells transfected with $5-\mathrm{HT}_{1 \mathrm{~A}}$ receptors and $\mathrm{SK}-\mathrm{N}-\mathrm{SH}$ cells endogenously expressing this receptor (Fricker et al., 2005). In addition, the involvement of the 5- $\mathrm{HT}_{1 \mathrm{~A}}$ receptor in dendritic morphology has also been demonstrated in culture of neurons extracted from the hippocampus or cortex of rat embryos. Rojas et al, (2014) showed growth of secondary dendrites in hippocampal neurons stimulated by $5-\mathrm{HT}$, an effect blocked by the antagonist WAY-100635, while Yoshida et al (2011) demonstrated effects on the density of dendritic spines of cortical neuron culture when treated with 8OH-DPAT.

However, the specific molecular mechanisms by which the $5-\mathrm{HT}_{1 \mathrm{~A}}$ receptor impacts neuronal morphology in the adult brain are not fully elucidated yet. Evidence indicates that the increase in the density of dendritic spines and the formation of new synapses occurs through the sequential activation of the ERK 1/2 and PKC pathways (Mogha et al., 2012; Rojas et al., 2016). Of note, NLX-101 has functional selectivity for ERK1/2 activation in vulnerable brain regions expressing postsynaptic $5-\mathrm{HT}_{1 \mathrm{~A}}$ heteroreceptors (Newman-Tancredi, 2009).

Also a decrease was observed in BDNF levels and the expression of SYN and PSD-95 in the PFC and hippocampus in the mice submitted to brain ischemia, an effect reversed by treatment with NLX-101. BDNF is a neurotrophic factor that plays an important role in regulating the survival of neurons, neurogenesis, and neuroplasticity (Begni et al., 2017). Favorable effects of BDNF on functional recovery and neuroplasticity after brain ischemia have been reported (Schäbitz et al., 2007; Espinera et al., 2013; Soares et al., 2016). All these results suggest that the effect of NLX-101 on BDNF levels may be associated with neuroprotective effects after ischemic insult. Moreover, both SYN and PSD-95 are the main proteins that participate in structural synaptic plasticity (SadighEteghad et al., 2018). The expression of SYN and PSD-95 markedly decreased in the 
hippocampus after experimental brain ischemia, and the recovery in the levels of these proteins in the hippocampus may determine the degree of functional recovery after an ischemic insult. In summary, the protective effects of NLX-101 on cortical and hippocampal neurons paralleled with their restorative or stimulating effect on the expression of BDNF, SYN and PSD-95, suggesting a relationship between these proteins, dendritic remodeling, and functional recovery after cerebral ischemia.

The hypothesis tested in this work (chapter 3 ) was based on preclinical studies that demonstrated that non-biased $5-\mathrm{HT}_{1 \mathrm{~A}}$ receptor agonists exerted neuroprotective effects in animals with cerebral ischemia (see chapter 2, table 2). However, the only clinical study with repinotan (a full $5-\mathrm{HT}_{1 \mathrm{~A}}$ receptor agonist) did not show any therapeutic benefits in patients with stroke (Teal et al., 2009). The cellular mechanism by which 5$\mathrm{HT}_{1 \mathrm{~A}}$ receptor agonists produce neuroprotection need more clarification and systematic studies. Only two studies confirmed direct $5-\mathrm{HT}_{1 \mathrm{~A}}$ receptor involvement by showing that the neuroprotective effect of $5-\mathrm{HT}_{1 \mathrm{~A}}$ receptor agonist was blocked by $5-\mathrm{HT}_{1 \mathrm{~A}}$ receptor antagonist, WAY100635 (Shaper et al., 2000; Mishima et al., 2005). The problem behind this issue is that classic $5 \mathrm{HT}_{1 \mathrm{~A}}$ receptor agonists indiscriminately activate both autoreceptors, which exert an inhibitory effect on serotonergic tone, and heteroreceptors located in projecting areas. In contrast, the biased $5-\mathrm{HT}_{1 \mathrm{~A}}$ receptor agonists that preferentially activate either raphe-located 5- $\mathrm{HT}_{1 \mathrm{~A}}$ autoreceptor or post-synaptic heteroreceptor might yield a more favorable therapeutic profile accompanied by a lower incidence of side effects, compared with the 5-HT1A receptor non-biased agonists. Although the results described herein suggested positive effects for NLX-101, it remains to be investigated whether the biased $5-\mathrm{HT}_{1 \mathrm{~A}}$ receptor agonism underlies the NLX-101 effects in cerebral ischemia conditions. Depending on the concentration, NLX-101 can also act as a conventional $5-\mathrm{HT}_{1 \mathrm{~A}}$ receptor agonist acting at both pre- and postsynaptic receptors. Besides, the window between biased and non-biased $5-\mathrm{HT}_{1 \mathrm{~A}}$ receptor activity can be small as 2-4 fold (Van Goethen et al., 2015).

Aging is another condition addressed in this thesis in which neuroplasticity is reduced. In addition, neurodegeneration and impaired hippocampal neurogenesis are age-related processes particularly related to the cognitive decline observed in elderly individuals, such as pattern separation (Drapeau and Nora Abrous, 2008). Pattern 
separation is a cognitive process that allows the formation of distinct representations out of similar inputs. There is evidence for a connection between adult neurogenesis and pattern separation (Clelland et al., 2009; Creer et al., 2010; Chen et al., 2012). The dentate gyrus (DG) of the hippocampus is one area of the brain where ongoing adult neurogenesis occurs (Zhao et al., 2008). One of the suggested roles for the adult neurogenesis of adult mammals is to assist the pattern separator in the DG, reducing the interference with old information (Clelland et al., 2009). If neurogenesis is down-regulated by aging, new information will be stored in overlapping cell groups and therefore memories can interfere with each other, leading to impaired pattern separation. Thus, pharmacological interventions that increase hippocampal neurogenesis targeting $5-\mathrm{HT}_{1 \mathrm{~A}}$ might represent an interesting strategy to improve pattern separation performance in old individuals.

Several studies evaluated the increase in hippocampal neurogenesis by activation of 5- $\mathrm{HT}_{1 \mathrm{~A}}$ receptor using different agonists. Santarelli et al. (2003), demonstrated that the therapeutic effects of antidepressants occurred due to a stimulus of hippocampal neurogenesis involving direct participation of $5-\mathrm{HT}_{1 \mathrm{~A}}$ receptors. Knockout mice for $5-\mathrm{HT}_{1 \mathrm{~A}}$ receptors showed a significant decrease in hippocampal neurogenesis and were unable to respond to chronic treatment with the antidepressant fluoxetine, a serotonin selective reuptake inhibitor (SSRI) (Santarelli et al., 2003). Accordingly, activation of the 5-HT $\mathrm{H}_{1 \mathrm{~A}}$ receptor by $8-\mathrm{OH}-\mathrm{DPAT}$, resulted in increased levels of neural progenitor cells in the DG of the hippocampus, an effect blocked by the 5-HT 1 A antagonist WAY-100635 (Banasr et al., 2004; Klempin et al., 2010; Soumier et al., 2010) or by the ERK 1/2 signaling inhibitor, U0126 (Cai et al., 2019). Chronic treatment of rats with tandospirone, a partial $5-\mathrm{HT}_{1 \mathrm{~A}}$ receptor agonist, also resulted in increased cell proliferation and neurogenesis (Rao and Shetty, 2014; Murata et al., 2015).

In the present thesis it was demonstrated that acute and repeated NLX-101 treatment reversed the effects of aging in the OPS task (Chapter 4). These results extend previous findings wherein NLX-101 has been shown to present beneficial effects in a pattern separation task (Van Goethem et al., 2015) and to alleviate the detrimental effects of phencyclidine (PCP) on memory in rats in the hole-board test (Depoortère et al., 2010). Also the molecular mechanism that could be involved in the beneficial effects of NLX-101 
in the OPS task was investigated. In accordance with previous studies, aged animals presented a reduction in the hippocampus of SYN, PSD-95 protein levels as well as neurogenesis, which were implicated in the learning and memory deficits (van Guilder et al., 2011). Because NLX-101 increased the BNDF protein levels, PSD-95 expression and neurogenesis in the hippocampus, it can be argued that NLX-101 acted on increasing pattern separation performance by improving neuroplasticity in the hippocampus of aged rats.

The results presented in this thesis demonstrate the relevance of the $5-\mathrm{HT}_{1 \mathrm{~A}}$ receptor as a pharmacological target for the treatment of different neuropsychiatric conditions. In the described studies, it is particularly evident that the activation of the postsynaptic receptor by the biased receptor agonist NLX-101, has a positive effect on specific neuroplastic processes that are related to functional recovery in aged rodents or rodents subjected to cerebral ischemia. 


\section{References}

Banasr M, Hery M, Printemps R, Daszuta A. 2004. Serotonin-induced increases in adult cell proliferation and neurogenesis are mediated through different and common 5HT receptor subtypes in the dentate gyrus and the subventricular zone. Neuropsychopharmacology. 29(3):450-60.

Bruel-Jungerman E, Davis S, Laroche S. 2007. Brain plasticity mechanisms and memory: a party of four. Neuroscientist. 13(5):492-505.

Bliss TV, Collingridge GL. 1993. A synaptic model of memory: long-term potentiation in the hippocampus. Nature. 361(6407):31-9.

Begni V, Riva MA, Cattaneo A. 2017. Cellular and molecular mechanisms of the brainderived neurotrophic factor in physiological and pathological conditions. Clin Sci (Lond). 131(2), 123-138.

Cai CY, Wu HY, Luo CX, Zhu DY, Zhang Y, Zhou QG, Zhang J. 2019. Extracellular regulated protein kinaseis critical for the role of $5-\mathrm{HT} 1$ a receptor in modulating nNOS expression and anxiety-related behaviors. Behav Brain Res. 357-358:8897.

Clelland C, Choi M, Romberg C, Clemenson G, Fragniere A, Tyers P, et al. 2009. A functional role for adult hippocampal neurogenesis in spatial pattern separation. Science. 325(5937):210-3.

Creer DJ, Romberg C, Saksida LM, van Praag H, Bussey TJ. 2010. Running enhances spatial pattern separation in mice. Proceedings of the National Academy of Sciences. 107(5):23Czech2.

Chen Q, Kogan JH, Gross AK, Zhou Y, Walton NM, Shin R, et al. 2012. SREB2/GPR85, a schizophrenia risk factor, negatively regulates hippocampal adult neurogenesis and neurogenesis-dependent learning and memory. European Journal of Neuroscience. 36(5):2597-608.

Dan B. 2019. Neuroscience underlying rehabilitation: what is neuroplasticity? Dev Med Child Neurol. 61(11):1240.

Drapeau E, Nora Abrous D. 2008. Stem cell review series: role of neurogenesis in agerelated memory disorders. Aging Cell. 7(4):569-589.

Depoortère R, Auclair AL, Bardin L, Colpaert FC, Vacher B, Newman-Tancredi A. 2010. NLX-101, a preferential post-synaptic 5-HT1A receptor agonist: activity in models of cognition in comparison with reference 5-HT1A receptor agonists. Eur Neuropsychopharmacol, 20(9):641-654.

Espinera AR, Ogle ME, Gu X, Wei L. 2013. Citalopram enhances neurovascular regeneration and sensorimotor functional recovery after ischemic stroke in mice. Neuroscience. 247, 1-11.

Fricker AD, Rios C, Devi LA, Gomes I. 2005. Serotonin receptor activation leads to neurite outgrowth and neuronal survival. Brain Res Mol Brain Res. 138(2):228-35.

Frankfurt M, Luine V. 2015. The evolving role of dendritic spines and memory: Interaction(s) with estradiol. Horm Behav. 74, 28-36.

Gulyaeva NV. 2017. Molecular Mechanisms of Neuroplasticity: An Expanding Universe. Biochemistry (Mosc). 82(3):237-242.

Hasbani MJ, Underhill SM, De Erausquin G, Goldberg MP. 2000. Synapse loss and regeneration: a mechanism for functional decline and recovery after cerebral ischemia? Neuroscientist. 6(2), 110-119. 
He H, Mahnke AH, Doyle S, Fan N, Wang CC, Hall BJ, Tang YP, Inglis FM, Chen C, Erickson JD. 2012. neurodevelopmental role for vglut2 in pyramidal neuron plasticity, dendritic refinement, and in spatial learning. J Neurosci. 32(45), 1588615901.

Klempin F, Babu H, De Pietri Tonelli D, Alarcon E, Fabel K, Kempermann G. 2010. Oppositional effects of serotonin receptors $5-\mathrm{HT} 1 \mathrm{a}, 2$, and $2 \mathrm{c}$ in the regulation of adult hippocampal neurogenesis. Front Mol Neurosci. 3:14.

Knafo S, Ariav G, Barkai E, Libersat F. 2004. Olfactory learning-induced increase in spine density along the apical dendrites of CA1 hippocampal neurons. Hippocampus. 14(7), 819-825.

Milner B, Klein D. 2016. Loss of recent memory after bilateral hippocampal lesions: memory and memories-looking back and looking forward. J Neurol Neurosurg Psychiatry. 87(3):230.

Mogha A, Guariglia SR, Debata PR, Wen GY, Banerjee P. 2012. Serotonin 1A receptormediated signaling through ERK and PKC $\alpha$ is essential for normal synaptogenesis in neonatal mouse hippocampus. Trans/ Psychiatry. 10;2(1):e66.

Murata Y, Yanagihara Y, Mori M, Mine K, Enjoji M. 2015. Chronic treatment with tandospirone, a serotonin $1 \mathrm{~A}$ receptor partial agonist, inhibits psychosocial stressinduced changes in hippocampal neurogenesis and behavior. J Affect Disord. 180:1-9.

Newman-Tancredi A, Martel JC, Assié MB, Buritova J, Lauressergues E, Cosi C, Heusler P, Bruins Slot L, Colpaert FC, Vacher B, Cussac D. 2009. Signal transduction and functional selectivity of F15599, a preferential post-synaptic 5-HT1A receptor agonist. Br. J. Pharmacol. 156(2), 338-353.

Rao MS, Shetty AK. 2004. Efficacy of doublecortin as a marker to analyse the absolute number and dendritic growth of newly generated neurons in the adult dentate gyrus. Eur J Neurosci. 19(2):234-46.

Rojas PS, Fiedler JL. 2016. What Do We Really Know About 5-HT ${ }_{1 A}$ Receptor Signaling in Neuronal Cells? Front Cell Neurosci. 10:272.

Rojas PS, Neira D, Muñoz M, Lavandero S, Fiedler JL. 2014. Serotonin (5-HT) regulates neurite outgrowth through 5-HT1A and 5-HT7 receptors in cultured hippocampal neurons. J Neurosci Res. 92(8):1000-9.

Schäbitz WR, Steigleder T, Cooper-Kuhn CM, Schwab S, Sommer C, Schneider A, Kuhn HG. 2007. Intravenous brain-derived neurotrophic factor enhances poststroke sensorimotor recovery and stimulates neurogenesis. Stroke. 38(7), 2165-2172.

Soares LM, De Vry J, Steinbusch HWM, Milani H, Prickaerts J, Weffort de Oliveira RM. 2016. Rolipram improves cognition, reduces anxiety- and despair-like behaviors and impacts hippocampal neuroplasticity after transient global cerebral ischemia. Neuroscience. 326, 69-83.

Sadigh-Eteghad S, Geranmayeh MH, Majdi A, Salehpour F, Mahmoudi J, Farhoudi M. 2018. Intranasal cerebrolysin improves cognitive function and structural synaptic plasticity in photothrombotic mouse model of medial prefrontal cortex ischemia. Neuropeptides. 71, 61-69.

Santarelli L, Saxe M, Gross C, Surget A, Battaglia F, Dulawa S, Weisstaub N, Lee J, Duman R, Arancio O, Belzung C, Hen R. 2003. Requirement of hippocampal 
neurogenesis for the behavioral effects of antidepressants. Science. 301(5634):805-9.

Soumier A, Banasr M, Kerkerian-Le Goff L, Daszuta A. 2010. Region- and phasedependent effects of $5-\mathrm{HT}(1 \mathrm{~A})$ and $5-\mathrm{HT}(2 \mathrm{C})$ receptor activation on adult neurogenesis. Eur Neuropsychopharmacol. 20(5):336-45.

van Goethem NP, Schreiber R, Newman-Tancredi A, Varney M, Prickaerts J. 2015. Divergent effects of the 'biased' 5-HT1 A receptor agonists NLX-101 and F13714 in a novel object pattern separation task. Br J Pharmacol, 172(10):2532-2543.

van Guilder HD, Farley JA, Yan H, Van Kirk CA, Mitschelen M, Sonntag WE, Freeman WM. 2011. Hippocampal dysregulation of synaptic plasticity-associated proteins with age-related cognitive decline. Neurobiol Dis, 43(1):201-12.

Yan W, Wilson CC, Haring JH. 1997. Effects of neonatal serotonin depletion on the development of rat dentate granule cells. Brain Res Dev Brain Res. 98(2):177-84.

Yoshida H, Kanamaru C, Ohtani A, Li F, Senzaki K, Shiga T. 2011. Subtype specific roles of serotonin receptors in the spine formation of cortical neurons in vitro. Neurosci Res. 71(3):311-4.

Zhao C, Deng W, Gage FH. 2008. Mechanisms and functional implications of adult neurogenesis. Cell. 132(4):645-60. 
CHAPTER 7

SUMMARY 
The present thesis aimed to demonstrate the involvement of $5-\mathrm{HT}_{1 \mathrm{~A}}$ receptors in different experimental conditions including cerebral ischemia and aging. It was hypothesized that selective activation of $5-\mathrm{HT}_{1 \mathrm{~A}}$ post-synaptic receptors by $\mathrm{NLX}-101$, a 'biased' $5-\mathrm{HT}_{1 \mathrm{~A}}$ receptor agonist, would increase neuroplasticity and promote functional recovery.

Chapter 1 represented the general introduction and aim for the research described in the thesis.

In chapter 2, the currently available data on the effects of $5-\mathrm{HT}_{1 \mathrm{~A}}$ agonists in experimental models of cerebral ischemia was summarized. The studies described in this review provide a clear demonstration that detrimental parameters associated with cerebral ischemia can be attenuated via activation of $5-\mathrm{HT}_{1 \mathrm{~A}}$ receptors. Such studies support the rationale for pursuing an investigation of this class of compounds and suggest that they could lead to promising pharmacotherapeutics for cerebral ischemic diseases.

In chapter 3 an experimental study using NLX-101 and the selective serotonin reuptake inhibitor (SSRI) Escitalopram (Esc) in mice with bilateral common carotid oclusion (BCCAO) was presented. NLX-101 attenuated cognitive impairments and despair-like behaviors in BCCAO mice. Moreover, NLX-101 blocked the increase in plasma corticosterone levels and restored hippocampal protein levels of plasticity markers including brain-derived neurotrophic factor (BDNF), synaptophysin (SYN), and postsynaptic density protein-95 (PSD-95). This compound also impacted positively dendritic remodeling in the hippocampus and PFC of ischemic mice. The results suggest that biased $5-\mathrm{HT}_{1 \mathrm{~A}}$ post-synaptic receptor agonists might constitute promising therapeutics for the treatment of functional deficits after brain ischemia.

Experimental and clinical evidence suggests that pattern separation linearly declines with increasing age. In chapter 4 the effects of acute and repeated treatment with NLX-101 on spatial object pattern separation (OPS) performance in aged rats were described. Aged rats were incapable to discriminate any new position of the objects in the arena, reflecting the detrimental effects of aging on OPS performance. However, when aged animals were treated acutely or repeatedly with NLX-101 they showed a significant cognitive improvement in the OPS task. This effect was accompanied by an increase in the BDNF and PSD-95 protein levels in the hippocampus of those animals. 
NLX-101 also stimulated neurogenesis (DCX-positive neurons) in the DG of the hippocampus of aged rats. These findings support a rationale for targeting cortical $5-\mathrm{HT}_{1 \mathrm{~A}}$ post-synaptic receptors as a strategy for treating cognitive impairments related to aging.

Chapter 5 presents the impact of CB1 receptor blockade on the behavioral and neuroplasticity effects of the SSRI Esc and the serotonin-norepinephrine reuptake inhibitors (SNSRI) velanfaxine (VFX) in mice submitted to the chronic unpredictable stress (CUS) paradigm. Chronic blockade of the CB1 receptor by the CB1 receptor antagonist AM251 attenuated the antidepressant-like effects of Esc, but not its anxiolyticlike effects. AM251, however, failed to change the antidepressant- and anxiolytic-like effects of VFX. On the other hand, AM251 attenuated the pro-proliferative effects of Esc in the dentate gyrus of the hippocampus. Moreover, Esc increased the expression of the CB1 receptor and PSD-95 in the hippocampus, an effect attenuated by AM251. These results suggest that antidepressants, in particular SSRIs, might exert their behavioral effects with a minor participation of CB1 receptors.

Taken together, the findings of the present thesis demonstrate that $5-\mathrm{HT}_{1 \mathrm{~A}}$ postsynaptic receptors could represent a promising pharmacological target to treat the detrimental consequences of cerebral ischemia and the cognitive decline due to aging. 


\section{VALORIZATION}

Cerebral ischemia is one of the principal causes of death and disability worldwide according to the World Health Organization and represents an increased economic burden due to treatment and post-ischemia care. In Europe, more than one million of new cases occur each year, and currently six million of survivors are estimated to be alive. In 27 European Union (EU) countries, the annual costs for brain ischemia treatment and care are estimated to be 27 billion euros, with 18.5 billion accounting for direct medical costs and 8.5 billion for indirect costs with loss of productivity for example. In the USA, a total of $\$ 65.5$ billion was spent on brain ischemia care in 2008 . The American Heart Association and The American Stroke Association projected for the years 2012 to 2030, that the total direct medical cost for brain ischemia will triple and reach up to $\$ 184.1$ billion. Costs related to brain ischemia care in Brazil are also considerable, with an aggregate national health care expenditures for the acute treatment of brain ischemia of $\$ 449.3$ million in 2006-2007. In face of the high costs and the economic impact behind this disease, the problem lies in the fact that advances in pharmacotherapy for cerebral ischemia have been limited. Therefore, the research and development of new drugs is imperative.

Global cerebral ischemia occurs commonly in patients who have a variety of clinical conditions including cardiac arrest, shock, asphyxia and in patients undergoing complex cardiac surgery. The commonest postulated mechanism for ischemic brain injury after cardiac arrest is global cerebral ischemia from systemic hypoperfusion affecting the whole brain. Irrespective of the etiology of cerebral ischemia, cellular and molecular processes trigger a cascade of events that culminate in a final common pathway, resulting in ischemic neuronal injury. Identification of these injury mediators and pathways in a variety of experimental animal models of global cerebral ischemia, such as bilateral common carotid artery occlusion as used in this thesis, has led to the investigation of target-specific neuroprotective strategies that are critical to clinical brain injury outcome.

Usually a patient who survives from cerebral ischemia, as also observed in rodents, may develop a vast number of neurological and neuropsychiatric disorders, including cognitive and/or affective dysfunctions. These impairments impact directly the costs regarding the health care of the patients. Thus, the effective treatment of the 
detrimental consequences of brain ischemia is relevant not only from a medical perspective but also from a socioeconomic standpoint.

Many different pharmacological strategies have been considered for the treatment of cerebral ischemia. In this context, some preclinical studies supported the idea that activation of the $5-\mathrm{HT}_{1 \mathrm{~A}}$ receptor with conventional agonists of this receptor, could have benefical effect on the consequences of cerebral ischemia in different animal models. Although these receptor agonists have shown interesting results in these preclinical studies, disappointed results were observed in clinical trials. The reason for this could be related to poor selectivity resulting in partial agonist, i.e. weak, activity on 5-HT $1 \mathrm{~A}$ receptors. Moreover, these receptor agonists activate indiscriminately both $5-\mathrm{HT}_{1 \mathrm{~A}}$ presynaptic autoreceptors and postsynaptic heteroreceptors, and this lack in receptor discrimination of $5-\mathrm{HT} 1_{\mathrm{A}}$ agonists may result in divergent or even opposite effects.

Interstingly, a new generation of so-calles biased receptor agonists has become available that discriminate between receptor subpopulations in specific brain regions. NLX-101, a biased postsynaptic 5-HT ${ }_{1 \mathrm{~A}}$ receptor agonist, has been extensively tested in preclinical studies and presents interesting antidepressant and pro-cognitive effects that could contribute to the treatment of the functional impairments after cerebral ischemia. In this thesis, for the first time to my knowledge, the effects of the biased 5- $\mathrm{HT}_{1 \mathrm{~A}}$ receptor agonist NLX-101 was evaluated in a mouse bilateral common carotid artery occlusion (BCCAO) model of brain ischemia. It was demonstrated that the functional deficits of these mice can be restored by selective $5-\mathrm{HT}_{1 \mathrm{~A}}$ post-synaptic activation.

In summary, it was shown that:

- NLX-101 attenuated cognitive impairments induced by BCCAO in mice.

- NLX-101 improved passive coping strategies of BCCAO mice in the forced swimming test.

- NLX-101 decreased basal plasma corticosterone levels in BCCAO mice.

- NLX-101 affected BDNF protein levels in the prefrontal cortex (PFC) and hippocampus of BCCAO mice.

- NLX-101 impacted dendritic remodeling in the PFC and hippocampus of BCCAO mice. 
- NLX-101 decreased neurodegeneration and increased synaptic plasticity markers in BCCAO animals.

Thus, direct targeting of a $5-\mathrm{HT}_{1 \mathrm{~A}}$ receptor subpopulation with biased agonists such as NLX-101 might constitute a new strategy for therapeutic intervention in brain ischemia patients.

Another topic addressed in this thesis is related to the cognitive decline caused by aging. Themes related to aging have been increasingly studied due to the increase in the elderly population in the world. The number of older persons (over 65 years old) that is an age above $X$ years, is expected to double again by 2050 , when it is projected to reach nearly 2.1 billion. An aging global population will have a serious impact on the world's economies to the point of hampering growth and changing public policy. Nations will be forced to improve their healthcare systems so they are more effective and efficient in order to provide better treatment for the elderly at a lower cost.

It is vital to understand how age impacts cognition and which preventative or treatment strategies might preserve cognition into advanced age. Pharmacological intervention aimed at enhancing or maintaining cognitive functions has been the focus of intensive research in the recent years. In this context, $5-\mathrm{HT}_{1 \mathrm{~A}}$ receptors have been shown to be involved in important aspects of cognitive function including attention, learning and memory, and neuroplasticity processes. Of note, acute administration of the biased 5$\mathrm{HT}_{1 \mathrm{~A}}$ receptor agonist NLX-101 has been shown to improve performance of healthy adult rats in the object pattern separation (OPS) task. In this thesis, it was demonstrated that aged rats presented a cognitive deficit in the OPS task, reflecting the detrimental effect of aging on pattern separation performance. Moreover, when these aged animals were treated acutely or repeatedly with NLX-101 they showed a cognitive improvement in the OPS task, and this effect was accompanied by an increase in neuroplasticity. These findings support the rationale for targeting post-synaptic cortical $5-\mathrm{HT}_{1 \mathrm{~A}}$ receptors as a treatment for cognitive deficits related to aging.

Clearly, the results from these studies provided new insights regarding the contribution of the $5-\mathrm{HT}_{1 \mathrm{~A}}$ receptor in improving plasticity and functional recovery in different neurological conditions. Specifically, the use of a new class of drugs known as biased 5-HT 1 A receptor agonists, e.g. the drug NLX-101, targeting the serotoninergic 
system could represent a promising strategy to treat cerebral ischemia diseases and cognitive decline due to aging. However, this issue needs to be investigated in future studies. More scientific evidence is needed to address whether biased $5-\mathrm{HT}_{1 \mathrm{~A}}$ agonism underlied the NLX-101 positive effects in cerebral ischemia and pattern separation in aged rats. Depending on the concentration, NLX can act as a conventional agonist at both pre-and postsynaptic receptors and, the range between biased and non-biased 5$\mathrm{HT}_{1 \mathrm{~A}}$ receptor agonism can be narrow. Thus, the present results could open up a new world of possibilities to be explored in the treatment of functional deficits impacting daily living and could represent a viable way to improve the quality of life of patients eventually. 


\section{CURRICULUM VITAE}

Rafael Pazinatto Aguiar was born on February $6^{\text {th }}, 1990$ in Santa Isabel do Ivaí, Paraná, Brazil. He graduated from high school at Colégio Loanda, Loanda, Paraná Brazil in 2007. In the following year, he started his Bachelor in Pharmacy at State University of Maringá, Maringá, Paraná, Brazil (2009 - 2014). In March of 2014 he was admitted as a Master student at State University of Maringá in the Post graduate Program of Pharmaceutical Sciences Graduate, Laboratory of Inflammation under supervision of $\mathrm{Dr}$ Roberto Kenji Nakamura Cuman. During this period, he had the opportunity to make his research interniship at University of Alberta, Faculty of Pharmacy and Pharmaceutical Sciences, Canada, where he developed studies regarding the synthesis and biological evaluation of new tyrosol-salicylate derivatives as potential anti-Inflammatory agents. After completed his Master's Degree, he was admitted in 2016 as PhD student in the same Post-graduate Program in the Laboratory of Neuropsychopharmacology under supervision of Dr Rúbia Maria Weffort de Oliveira, where he started with the topic of this thesis. During his PhD he spent 8 months in the School for Mental Health and Neuroscience at Maastricht University under supervision of Prof. Dr. Jos Prickaerts, as part of a Programme of International Cooperation between UEM and The University of Maastricht, CAPES/NUFFIC (88887.197575/2018-00). During his PhD, Rafael Pazinatto Aguiar investigated the contribution of $5-\mathrm{HT}_{1 \mathrm{~A}}$ receptor as a target for functional recovery in cerebral ischemia and aging. 


\section{LIST OF PUBLICATIONS}

\section{Journal aticles}

1. Gonçalves DS, Melo SMS, Jacomini AP, Silva MJV, Pianoski KE, Ames FG, Aguiar RP, Oliveira AF, Volpato H, Bidóia DI, Nakamura CV, Bersani-Amado CA, Back DF, Moura S, Paula FR, Rosa FA. Synthesis Of Novel 3,5,6-Trisubstituted 2Pyridone Derivatives And Evaluation For Their Anti-Inflammatory Activity. Bioorganic \& Medicinal Chemistry. 2020, 28:12, 115549.

2. Aguiar RP, Soares LM, Meyer E, Da Silveira FC, Milani H, Newman-Tancredi A, Varney M, Prickaerts J, Oliveira RMW. Activation of $5-\mathrm{HT}(1 \mathrm{~A})$ postsynaptic receptors by NLX-101 results in functional recovery and an increase in neuroplasticity in mice with brain ischemia. Prog Neuropsychopharmacol Biol Psychiatry. 2019, 99:109832.

3. Aguiar, RP; Aldawsari FS; Wiirzler LAM; Silva-filho SE; Silvacomar FMS; BersaniAmado CA; Velazquez-Martinez CA; Cuman RKN. Synthesis and biological evaluation of new tyrosol-salicylate derivatives as potential antiinflammatory agents. Current Pharmaceutical Design. 2017, 23:6841-6848.

4. Uchida NS; Silva-Filho SE; Aguiar RP; Wiirzler LAM; Cardia GFE; Cavalcante HAO; Silva-Comar FM; Becker TCA; Silva EL; Bersaniamado CA; Cuman RKN. Protective effect of Cymbopogon citratus essential oil in experimental model of acetaminophen-induced liver injury. Am J Chin Med. 2017, 45:1-18.

5. Aldawsari FS; Aguiar RP; Wiirzler LAM; Aguayo-Ortiz R; Aljuhani N; Cuman RKN; Medina-Franco José L; Siraki Arno G; Velázquez Martínez CA. Anti-inflammatory and Antioxidant Properties of a Novel Resveratrol salicylate Hybrid Analogue. Bioorg Med Chem Lett. 2016, 1411-1415.

6. Wiirzler LAM; Aguiar RP; Velazquez-Martinez CA; Cuman RKN. Anticancer activity of eugenol is not related to regulation of the oncogenic transcription factor Forkhead Box M1. Acta Scient Health Sci. 2016, 38:159.

7. Silva-Filho SE; Wiirzler LAM; Cavalcante HAO; Uchida NS; Silvacomar FM; Cardia GFE; Da Silva El; Aguiar RP; Bersani-Amado CA; Cuman RKN. Effect of Patchouli (Pogostemon cablin) essential oil on in vitro and in vivo leukocytes behavior in acute inflammatory response. Biomed Pharmacother. 2016, 84:,16971704. 
8. Wiizler LA; Silva-Filho SE; Aguiar RP; Cavalcante HAO; Cuman RKN. Evaluation of Anti-inflammatory Activity of estragole by modulation of eicosanoids production. Int J Pharma Chem Res. 2016, 2:7-13.

9. Freitag AF; Cardia GFE; Ambrósio BA; Aguiar RP; Silva-Comar, FMS; Spironello RA; Grespan R; Caparroz-Assef SA; Bersani Amado CA; Cuman RKN. Hepatoprotective Effect of Silymarin Silybum marianum on hepatotoxicity induced by cetaminophen in spontaneously hypertensive rats. Evid Based Complement Alternat Med. 2015, 1-8.

10. Pinho RJ; Aguiar RP; Spironello RA; Silva-Comar FMS; Silva-Filho SE; Nogami EM; Bersani-Amado CA; Cuman RK. Hepatoprotective effect of pretreatment with Rosemary and ginger essential oil in experimental model of acetaminopheninduced Injury. Brit J Pharm Res. 2014, 4:2126-2135.

11. Grespan R; Aguiar RP; Giubilei FN; Fuso RR; Damião MJ; Silva EL; Mikcha JM; Hernandes L; Bersani-Amado CA; Cuman RKN. Hepatoprotective effect of pretreatment with Thymus vulgaris essential oil in experimental model of acetaminophen-induced injury. Evid Based Complement Alternat Med. 2014, 1-8.

\section{Publications in progress}

1. Aguiar RP; Ribeiro MA, Fusse EJ; Scarante FF; Oliveira RMW; Guimarães FS; CAMPOS AC. Involvement of the type-1 cannabinoid receptor (CB1) in behavioral and neuroplastic effects of the antidepressants in male mice submitted to chronic unpredictable stress.

2. Aguiar RP; Ribeiro MA, Fusse EJ; Scarante FF; Oliveira RMW; Guimarães FS; Campos AC. The pharmacological blocked of $\mathrm{CB} 2$ receptors in mice submitted to chronic unpredictable stress mice improve copying behavior and reduces the expression of immature neurons Doublecortin in the hippocampus.

3. Aguiar RP; Soares LM; Milani H; Varney M; Newman-Tancredi A; Prickaerts J; Oliveira RMW. NLX-101, a biased 5-HT1A receptor agonist, improves pattern separation and stimulates neuroplasticity in aged rats.

4. Aguiar RP; Newman-Tancredi A; Prickaerts J; Oliveira RMW. Serotonin 5-HT1A receptors as a potential target for neuroprotection in cerebral ischemia. 


\section{ACKNOWLEDGMENTS}

First of all, I would like to thank my family. My mother Sirlei, my father José and my brother Fabio who always gave me unconditional support in all the choices of my life. Without you, absolutely none of this would be possible. Thank you for being a solid support and believing in my dreams. I love you.

To my supervisor in Brazil, Dr. Rúbia Weffort, for having accepted the challenge of guiding a student like me, who decided to change the research area and start a new journey from scratch. Thank you for being this example of advisor, professor and scientist and for all the support given throughout the doctorate. For believing in my potential, for all the optimism transmitted and for helping me to find a solution in moments of despair.

A big thanks goes to Professor Dr. Jos Prickaerts, my supervisor at Maastricht University, for having accepted me into his laboratory for the sandwich doctorate. Thank you so much for the opportunity and for having been by my side during the most difficult moments of that period. An experience I will never forget. Dank je wel.

To Professor Dr. Humberto Milani, for being an example of integrity and for always being available to help me with statistical analysis.

To Professor Dr. Alline Campos, for having opened the doors of her laboratory at FMRP-USP so that I could develop a project and learn a lot about neurosciences. It was certainly a period of intense learning. I thank you wholeheartedly for having believed in me and for giving me the opportunity to be part of the history of your laboratory.

To the friendships made during the period I was in Ribeirão Preto, Franciele, Eduardo, Melissa, Paula, Davi, Adrielle, Fernanda, Mariana and Naiely. It was a pleasure to do science with people as dedicated and intelligent as you. I will never forget the best hangouts and our discussions about the origin of the universe.

Thanks to all members of our Lab in Brazil, Jéssica, Daniela, Erika, Marco, Bianca, Emanuela and Jacqueline for putting up with me in times of despair, for the partnership and for so many laughs in our routine during the experiments. You are incredible researchers. 
Special thanks to Dr. Lígia Mendes Soares. Your contributions to the experiments was fundamental to this work.

To my colleagues Ellis, Dean and Manon from the laboratory at University of Maastricht. Ellis, thanks for all your support, for the many laughs and lunches together. You are a special girl.

To Luiz Kanazawa for all our adventures during the sandwich doctorate and for all the support.

To my friend Erika, the most beautiful German in the world. We started this journey at the same time back in the master's degree and since then we have been going together. Thank you for all the advice, for being a friendly shoulder, for helping me with the experiments and for leaving Germany to help me in Holland when I needed a real friend by my side. I keep your friendship in my heart and I thank God that our paths have crossed.

To my friend Gustavo Moreno, who has been with me since the beginning of this academic journey, supporting me, advising and listening to my follies whenever I need a safe haven. You are a brother that life has given me and I thank you for everything my friend.

To my best friends, Kelly, Camila, Eduarda, Barbara, Naiana, Tamiris and Luisa, for the partnership since college. Your friendship has always been very important to me and I want to take you with me for the rest of my life. Love you. 